\title{
THE DEVELOPMENT OF THE ALBINO RAT, MUS NORVEGICUS ALBINUS
}

\author{
I. FROM THE PRONUClEAR STAGE TO THE STAGE OF MESO- \\ DERM ANLAGE; END OF THE FIRST TO THE END \\ OF THE NINTH DAY \\ G. CARL HUBER
}

From the Department of Anatomy, University of Michigan, and the Division of Embryology, Wistar Institute of Anatomy and Biology, Philadelphia

THIRTY-TWO FIGURES

\section{CONTENTS}

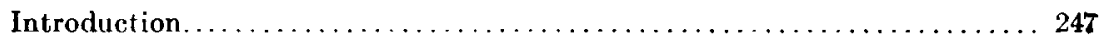

Material and methods.................................. 249

Ovulation, maturation, and fertilization........................ 253

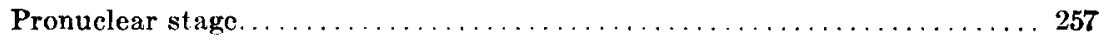

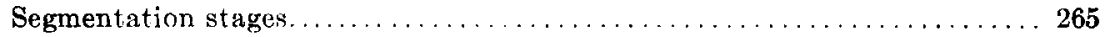

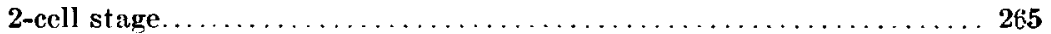

4-cell stage ........................................ 273

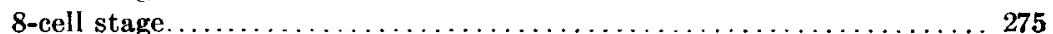

12 to 16 -cell stage.................................... 279

Summary of segmentation stages, rate, and volume changes........... 280

Completion of segmentation and blastodermic vesicle formation......... $2 \varepsilon 6$

Blastodermic vesicle, blastocyst, or germ vesicle................ 300

Late stages of blastodermic vesicle, beginning of entypy of germ layers. . . 307

Development and differentiation of the egg-cylinder............... 317

Late stages in egg-cylinder differentiation, and the anlage of the nesoderm 336

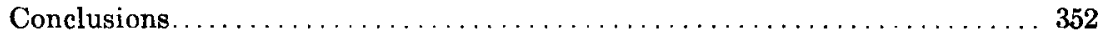

Literature cited...................................... 356

\section{INTRODUCTION}

The early developmental stages of placental mammals, embracing the stages of sex cell maturation and fertilization, of segmentation, of blastodermic vesicle and germ layer formation, though subject of numerous contributions extending over many years, have in no form been completely investigated. The literature dealing with the phenomena of maturation and fer- 
tilization as observed in placental mammals has in recent years been enriched by a number of studies to the extent that for certain of the mammals-bat, rabbit, guinea-pig, mouse, and rat-the data at hand are sufficiently complete to enable a clear and comprehensive presentation, based an observed facts, and permit of comparison with similar phenomena as observed in other vertebrate and invertebrate forms. As concerns the process of segmentation in placental mammals, there are still lacking sufficiently comprehensive observations embracing a number of forms to enable a clear and succinct presentation of the rate of blastomere formation, the cytomorphosis of the cells, and of the relative position of the several segmentation stages in the genital tract. This is no doubt owing to the difficulty of obtaining the necessary material timed so as to admit of proper staging, and the impossibility of making extended observations on living material. Our knowledge of the phenomena of blastoderm vesicle formation, though comprehended in its general phases, is lacking in detail, except for a very limited number of forms. The process of germ layer formation is of such fundamental importance to a clear comprehension of later developmental stages, both in phylogeny and in ontogeny, that a brief account of observed facts in any one form may not be regarded as wholly without value.

Opportunity presented itșelf, while stationed at The Wistar Institute of Anatomy and Biology, to collect and fix an extended series of embryological stages of the albino rat. This material has proven sufficiently comprehensive to enable a presentation of the several developmental stages of this mammal, beginning with the pronuclear stage and extending to the stage of the anlage of the mesoderm. For this period, which extends to about the tenth day after insemination, only very few of the essential stages are lacking, though for certain of the stages confirmatory preparations would have been desirable. The material at hand, however, seemed sufficiently complete to present a connected account of the stages it is hoped to cover. The embryology of allied forms, especially of the mouse, has received much more extended study than has that of the rat, though the develop- 
ment of the rat has received especial consideration by Fraser, Christiani, Selenka, Duval, Robinson, Widakowich, and as concerns maturation and ovulation, by Sobotta and Burckhard, Kirkham and Burr. The pertinent literature will be considered in connection with the presentation of my own results.

\section{MATERIAL AND METHODS}

The material on which this investigation is based was obtained from albino rats (Mus norvegicus albinus, Donaldson) ${ }^{1}$ taken from the extensive rat colony of The Wistar Institute of Anatomy and Biology. The experience gained in the breeding, feeding, and growth experiments, extending over many years, conducted by Donaldson and his associates and resulting in numerous excellent publications, was at my disposal while collecting this material. The material used was all carefully timed, so that sequence of stages was obtained with some degree of certainty. With care and experience, it is possible to regulate and observe insemination, so that stages may be approximated quite accurately. Kirkham and Burr state that "on several different occssions we have observed actual pairing" of the albino rat. Widakowich states that he was unable to obtain accurate data as to the age of the embryos except by observing coitus. According to this observer, a female rat permits many males to copulate in the course of several hours, receiving males 30 times or oftener, when suddenly she drives them away. Sobotta and Burckhard, on the other hand, admitted males a few hours after parturition, depending on the fact that many mammals ovulate soon after parturition. Though attempts were made, they were unable to observe pairing, and they state that the 'Dieners' charged with the care and feeding of the rat colony were only seldom able to observe attempts at pairing. At The Wistar Institute no difficulty is experienced in pairing albino

\footnotetext{
${ }^{1}$ Melissinos and Widakowich state having used as material the albino rat, variety Mus rattus albinus. Donaldson has conclusively shown, that by reason of physical characters-blood erystals, shape of the skull, etc.-the albino rat kept as pet or laboratory animal cannot be Mus rattus albinus, but must be Mus norvegicus albinus.
} 
rats. Dr. J. M. Stotsenburg, to whose experience and careful records I am greatly indebted for the trustworthiness of the material collected, made use largely of females who had born one litter. Pairing was seldom attempted a few hours post partem, as was done by Sobotta and Burckhard, but usually about 30 days after the birth of a litter, which may have been nursed or otherwise disposed of. The great majority of females used in pairing were at the time free from 'domestic cares.' The females employed were kept in separate cages for some time before giving birth to young and until the time of mating. About 30 days after the birth of a litter, a male was placed in the cage with the female. If the female was in heat, copulation usually took place soon after. The male was left with the female for an hour to an hour and a half, during which time several pairings would occur, and at the end of which time the female would try to hide from the male, climb the side of the cage and defy him with her teeth. The male albino rat is not prostrated by the sexual act, the same male serving for several successive copulations. In case the female was not in heat, this soon became evident and the male removed, to be again placed into her cage 24 or 48 hours later. The time when the copulation was first observed was noted on the card attached to the cage and gave the time from which the age of the embryo or respective stage was reckoned. The time given is, therefore, that of 'insemination,' a term which Long and Mark have introduced to indicate "the introduction of the male sexual elements into the genital tracts of the female by the act of coitus or otherwise." This time could be accurately noted, while 'semination' which "applies to the access of the spermatozoa to the eggs in the oviducts, the coming into contact of the male and female reproductive cells" can not be accurately timed. The success attained in pairing albino rats as above stated, obviated the necessity of depending upon chance material or resorting to 'artificial insemination' as described for the mouse by Long and Mark. I am at loss to understand why Widakowich should regard the age determinations of Sobotta and Melissinos (mouse embryos) more accurate than his own, reckoned from the time 
of observed coitus. The slight though observable variation in the rate of development in a series of ova of the same animal, more marked when supposedly similar stages of several animals are investigated, precludes the accurate timing of stages.

As fixing fluids, there were used Zenker's fluid, sublimatealcohol, Flemming's fluid, Bouin's fluid, and Carnoy's fluid. After a few trials, all were discarded in favor of Carnoy's fluid, prepared by mixing 6 parts of absolute alcohol, 3 parts of chloroform, and 1 part of glacial acetic acid. This somewhat illogically compounded fluid penetrates rapidly and does not cause shrinkage. Tissues are fixed in it for several hours, then washed in several changes of absolute alcohol in which it has been my custom to store the tissues. The following procedure was practiced in all stages up to about 12 days after insemination: The animals were anaesthetized and the head severed from the body, to admit of free bleeding. The rat was then fastened to a board, and thorax and abdomen opened by a mid-sagittal incision, the abdominal walls pinned back, and the intestine elevated toward the thorax. With as little manipulation as possible, the ovaries were separated from their attachment, the mesometrium cut, the uterine horns elevated and the vagina severed. The whole genital tract was then placed on a clean slide and arranged in approximately normal position. Slight tension was maintained by tying a thread to the connective tissue removed with each ovary and bringing the threads along the reverse side of the slide and tying them to the vagina. If the slide is clean, the mesometrium of each uterine horn may be spread out evenly and caused to adhere to the slide. Ovaries, oviducts, and uterine horns may thus be spread out in normal position and each uterine horn fixed as a straight tube. When thus arranged on the slide, the preparation was placed in a relatively large quantity of Carnoy's fluid, fixed, and then transferred through several absolute alcohols. For nearly all the material used in this study, the method of fixation was as here given. In the earlier stages of material collection, attempts were made to obtain segmentation stages in warm normal salt solution. Several were thus obtained and were used to control 
the observations made on sections, as will be discussed later. By cutting the oviduct at about its middle, freeing it from its mesosalpinx and cutting the uterus about $1 \mathrm{~cm}$. below the insertion of the oviduct, a pipette fitted with a rubber bulb and filled with warm normal salt solution can be inserted into the uterine cavity and moderate pressure made. It is usually possible to wash into a watch crystal a certain number of the contained segmenting ova. Before reading the article by Widakowich, essentially the same method as employed by him, for isolating implanted blastodermic vesicles was developed. This may be quite readily done after fixation in Carnoy's fluid and teasing under a stereoscopic binocular. Vesicles sectioned in situ, however, gave on the whole more satisfactory results, so that teasing out implanted vesicles was not resorted to.

The fixed tissues were imbedded in paraffin, using xylol as a clearing fluid. For stages including those falling within the period ranging from the first to the fourth day after insemination, the ovary and oviduct to its insertion in the uterus, were embedded en masse. For stages falling within the period of fifth to sixth day after insemination, the uterine horns were divided into segments measuring about $1.5 \mathrm{~cm}$., and sectioned parallel to the plane of the mesometrium. For later stages, after the enlargements in the uterine horns are distinctly evident, these were removed and cut severally in the three planes. The great majority of the sections were cut at a thickness of $10 \mu$; certain ones at a thickness of $5 \mu$; a few at a thickness of $7 \mu$. The sections were fixed to the slide by the water-albumen method. The great majority of the series were stained in hemalum, counterstained in Congo red. This solution, which presents certain advantages as a counterstain for embryologic tissues, is prepared as follows: $\mathbf{0 . 5}$ gms. of Congo red (Grübler) is placed in $100 \mathrm{ccm}$. of distilled water and the water brought to boiling. This should give a clear solution. Before cooling, add $100 \mathrm{ccm}$. of distilled water and $10 \mathrm{ccm}$. of absolute alcohol. The Congo red solution thus prepared may be kept many weeks. After staining the series in the usual way in hemalum, they are differentiated in acid alcohol, and passed through several washes of 'tap water' into distilled 
water. They are then stained in the Congo red solution, which may be diluted with distilled water about five times. With the diluted solution, the counterstaining requires one to two hours. The sections are then rinsed in distilled water, differentiated in 80 per cent alcohol, dehydrated, cleared, and mounted in damar. Certain of the series were stained in Heidenhain's iron-hematoxylin and counterstained in Congo red. The drawings accompanying this contribution were nearly all drawn on coarse 'Ross board,' with the aid of the camera lucida at a magnification of 1000 diameters, using pencil and India ink. Such drawings admit of liberal reduction, and give a detail not readily obtained otherwise. Free use has been made of the Born method of reconstruction, especially for earlier stages. The majority of the models thus obtained are here reproduced.

I desire to express my sincere thanks and appreciation of the very material aid given me by Mr. Wayne J. Atwell, then Assistant in the Department of Histology and Embryology of the University of Michigan, in the making of the reconstructions of the oviducts included in this account.

\section{OVULATION, MATURATION, AND FERTILIZATION}

When this study was projected, it was the purpose to begin it with the stages of maturation and fertilization. During the time of material collection, there appeared the contribution of Sobotta and Burckhard: "Reifung und Befruchtung des Eies der Weissen Rate," covering these stages fairly completely. Duplication of their work did not seem necessary, so that my own studies begin with the pronuclear stage, to which stage the above mentioned investigators had carried their observations. Therefore, as concerns the process of ovulation, maturation, and fertilization as observed in the albino rat, I am confined for my data to the literature; from which a brief résumé is here made.

The normal gestation period for non-lactating albino rats may be roughly estimated as from 21 to 23 days. As has been shown by King, the period of gestation of lactating albino rats varics 
from a minimum of 24 days to a maximum of 34 days. The average number in a litter is six. In lactating females suckling five or less young and carrying five or less young, the period of gestation usually does not exceed 23 days and may thus be considered as normal. In lactating females suckling five or less young, while they are carrying more than five young, the period of gestation may be prolonged from one to six days. In lactating females suckling more than five young, the period of gestation is always prolonged, and may be prolonged to a maximum of 34 days. Daniel's studies on the white mouse lead him to formulate the following law: "The period of gestation in lactating mothers varies directly with the young suckled." Such exact relation between the number of young suckled and the extent of the prolongation of the gestation period was not observed by King for the albino rat.

In the albino rat, ovulation occurs spontaneously and is not dependent on copulation, which act, however, may precede or follow ovulation. Kirkham and Burr state that ovulation usually occurs about 24 hours after parturition and that the developing ova can be traced in the ovary through the two oestrus cycles preceding their discharge. Long, in his study No. 3, by Mark and Long, finds that ovulation must occur in the albino rat on an average not less than 18 hours after parturition. Sobotta and Burckhard state that ovulation always occurs within 36 hours post partem, though at very variable periods, often only a few hours after the completion of parturition; again, much later. A second ovulation period apparently occurs some 30 days post partem, as would appear from the successful pairings conducted by Dr. Stotsenburg. This agrees with the observations of Melissinos, who found that pairings were more numerous when attempted 29 days after parturition, than when attempted 20 to 21 days after parturition, as practiced by Sobotta. Semination probably takes place in the ampullar portion of the oviduct. Relatively few spermatozoa enter the oviducts and Sobotta and Burckhard estimate that the life of the spermatozoa in the genital tracts of the albino rat is only about 10 hours. 
The phenomena of maturation and fertilization in the albino rat have been carefully studied by Sobotta and Burckhard, from whose account the following brief summary is taken: The behavior of the ovum of the albino rat with respect to the formation of polar bodies is very similar to that of most other mammals studied. The first polar body is given off within the ovarian follicle, the second in the oviduct and only after semination. The first maturation spindle, developed from the nucleus of the oocyte of the first order, forms usually immediately after parturition. Kirkham and Burr state "it is usually formed less than 24 hours after parturition." It is short and broad, with the chromatin scattered. The first maturation spindle lies near the center of the ovum, then passes toward the surface assuming a tangential position, and only with the beginning of metakinesis, takes a radial position. The chromosomes of the first maturation spindle, estimated as numbering 16 , appear in the form of modified rings, which are divided transversely across to form short rounded rods with a longitudinal direction in the diaster stage. The first polar body is formed in the ovarian follicle and appears to be relatively large. It is evident only in the ovarian ovum, and appears to be lost soon after its formation. Its fate is doubtful. The first polar body is nearly always missing in tubal ova. Kirkham and Burr state that "the rare occurrence of the first polar body associated with the egg in the tube is to be attributed to its rapid disintegration, which begins as soon as it is formed, and may lead to complete disappearance before ovulation occurs." The second maturation division begins immediately after the completion of the first, without an intervening resting phase. The spindle formed is narrower and longer than the first, with the chromatin massed. In its monaster stage, it lies in a tangential position, with the chromatin in diads, and with the lines of division at right angles to the axis of the spindle. The appearance of the second maturation spindle in the monaster stage marks the end of the maturation phenomena in the ovary. The monaster stage of the second oocyte division was not observed in the ovary by Sobotta and Burckhard, but was seen by Kirkham and Burr. The first 
division Sobotta and Burckhard regard as a reduction division, a heterotypic longitudinal division; the second as an equatorial division, a homeotypic longitudinal division. Ovulation probably occurs during the monaster stage of the second maturation division.

The tubal ova are surrounded by a relatively thin oolemma to which are adherent a variable number of discus cells. They are smaller than the ovarian ova; the latter measuring $60 \mu$ to $65 \mu$, the tubal ova $55 \mu$ to $60 \mu$. The recently discharged tubal ova are to be found in the distended ampullar portion of the oviduct, where they are found clumped together surrounded by discus cells. Semination takes place in this region. The spermatozoa usually enter while the tubal ova are in the monaster stage of the second maturation division, after which metakinesis begins. The second maturation spindle assumes a radial position in the metakinctic phase. The second polar body is smaller than the first, and usually lies compressed between the oolemma and the ooplasm, and is evident during fertilization and segmentation. The spermatozoan head penetrates the thin oolemma and the ooplasma; the long middle piece and tail following the head into the ooplasma, as has been shown by Coe, and Kirkham and Burr. The long middle piece, soon after penetrating the ooplasma, presents an increase in stainability, and its spiral thread becomes evident. The spiral thread, as Duesberg has shown, has its origin in the mitachondria of the spermatid. It may be, therefore, that the male sexual cell introduces mitachondria to the egg cell at the time of fertilization. Some little time after the penetration of the sperm head, this enlarges and becomes vacuolated, and diplosomes with polar rays become evident. As the sperm head begins to metamorphose, tending to the formation of the male pronucleus, the chromosome group of the dispireme of the second maturation spindle, undergoes metamorphosis to form the female pronucleus. This enlarges rapidly to form a vesicular nucleus which lies free in the ooplasm, while the metamorphosing male pronucleus, usually smaller, is accompanied by a deeply staining thread-like structure, derived from the middle piece. The centrosomes of the 
first segmentation spindle are by inference derived from the sperm centrosome. The data here given, as concerns the maturation and fertilization phenomena pertaining to the albino rat, unless otherwise credited, have been drawn from the account of Sobotta and Burckhard, whose account is accompanied by excellent figures.

Long has studied in living ova of mice and rats the phenomena of maturation and fertilization. Tubal ova were placed in Ringer's solution on an especially constructed slide and spermatozoa introduced. It was possible to seminate the ova of rats with rat spermatozoa and to observe the formation of the second polar body. The formation of the second polar body, "usually near the first polar cell, may begin within five minutes to two or more hours after the spermatozoa are introduced. The constriction may be finished three-fourths of an hour later." "The first appearance is an elevation clearer than the rest of the cell. The swelling becomes higher, and at one side of the elevation there appears a depression which is the beginning of the constriction which presently encircles the whole swelling and cuts it off from the egg." Nothing could be said as to the changes which the chromatin undergoes after the spermatozoa have penetrated the egg. The eggs remained alive and apparently normal for about twelve hours, after which they began to degenerate.

\section{PRONUCLEAR STAGE}

As has been stated, my own observations on the development of the albino rat (Mus norvegicus albinus) begin with the pronuclear stage. The material at hand for this stage is listed in table 1 , page 258 .

Thus there are present in the series 34 ova showing a pronuclear stage and 9 ova showing the second maturation spindle in the monaster phase. The latter may be dismissed with the brief statement that they represent unfertilized ova. In rat No. 108, with 7 ova in the stage of the second maturation spindle, killed 24 hours after the observed copulation, there was found no trace of spermatozoa in the oviduct. Two reasons may be offered for the non-appearance of fertilization in this case: 
TABLE 1

\begin{tabular}{|c|c|c|c|c|}
\hline \multirow{2}{*}{$\begin{array}{l}\text { RECORD } \\
\text { NUMBER }\end{array}$} & \multirow{2}{*}{$\begin{array}{l}\text { HOURS AFTER BEGINNING } \\
\text { OF INEEMINATION }\end{array}$} & \multirow{2}{*}{$\begin{array}{l}\text { NUMBER OF } \\
\text { OVA }\end{array}$} & \multicolumn{2}{|c|}{ BTAGE OF REVELOPMENT } \\
\hline & & & Pronuclear & $\begin{array}{l}\text { Second matu- } \\
\text { ration spindle }\end{array}$ \\
\hline 106 & 24 hours & 8 & 8 & \\
\hline 107 & 24 hours & 11 & 10 & 1 \\
\hline 108 & 24 hours & 7 & & 7 \\
\hline 109 & 24 hours, $15 \mathrm{~min}$. & 9 & 8 & 1 \\
\hline \multirow[t]{2}{*}{110} & 24 hours, $15 \mathrm{~min}$. & 8 & 8 & \\
\hline & Tota] & 43 & 34 & 9 \\
\hline
\end{tabular}

Ovulation may have occurred so late that the spermatozoa may have died before the ova reached the ampullar portion of the oviduct. This explanation, it would seem, is invalidated by the fact that the position of the ova in the oviduct, as shown by graphic reconstruction, is essentially the same as in the other four rats studied, and in which fertilized ova were found, so that ovulation must have preceded the killing of the animal by some hours. The other reason, more plausible, attributes non-fertilization to a pathologic condition of the genital tract. In this rat, one ovary was distinctly pathologic, with periovarian capsule greatly distended with a sanguinous liquid, while the upper end of the uterine horn with adjacent oviduct on the other side, as seen in sections, presented evidence of inflammation and epithelial desquamation, in part occluding the lumen. It seemed evident, therefore, that the spermatozoa introduced in the genital tract were unable to penetrate to the oviduct and consummate fertilization. The other two unfertilized ova, found with ova in the pronuclear stage, were in oviducts in which no spermatozoa were found. Both in the mouse and the rat, relatively few spermatozoa reach the upper end of the oviduct; too few, it would seem, to consummate fertilization of all the ova in certain cases. In all of the ova which contained the second maturation spindle, this was in the monaster phase and in tangential position. In size, shape, and chromatin configuration, all presented the characteristics described and figured by Sobotta and Burckhard and Kirkham and Burr, therefore, need not be considered further. 
The stage of pronuclei was observed in over 100 ova of the white rat by Sobotta and Burckhard. According to these observers, the two pronuclei show in the earlier stages of their development, large chromatin-like nucleoli, the number of which varies. Some little time later, one or several such chromatoid nucleolar bodies with irregularly formed chromatin masses arranged on the linin network are to be observed. At a still later time, the chromatin becomes distributed over the linin network, throughout the nuclear space, giving the appearance of a fine chromatin network. One of the pronuclei is, as a rule, somewhat smaller than the other. This is regarded as the male
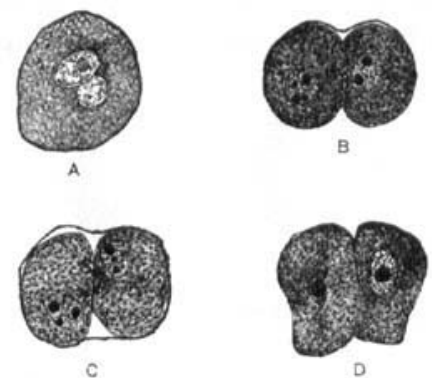

Fig. 1 Tubal ova, albino rat. $\times 200$. A, rat No. 110,24 hours, 15 min., ovum in pronuclear stage, larger nucleus temale pronucleus; $B$, and $C$, rat No. 59, 2 days, 2-cell stages, thin oolemma showing in $\mathrm{C}$, only partially seen in B; D, rat No. 62, 2 days, 22 hours, 3-cell stage, the nucleus of the unsegmented blastomere in the monaster phase, only one of the other two cells showing in the figure.

pronucleus, since near it the 'sperm centrum' was now and then observed. The pronuclei lie in about the center of the ovum. The pronuclear stages of my own material, observed in 34 ova, obtained 24 hours after the beginning of insemination-thus at the end of the first day of development-all present essentially the same stage of metamorphosis. As may be seen in A of figure 1, the nuclei are distinctly membraned, and are of relatively large size. The ovum here sketched measures in the stained preparation $70 \mu$ by $62 \mu$, and is, therefore, of slightly oval form. Sobotta and Burckhard give $55 \mu$ to $60 \mu$ as the size of the tubal ova, and $60 \mu$ to $65 \mu$ as the size of the ovarian ova in 
the white rat. Kirkham and Burr give the diameter of the living unsegmented egg of the rat as of $0.079 \mathrm{~mm}$. As may be seen from $A$ and $B$, of figure 2 , the tubal ova, even when free in the oviduct, are not of necessity spherical in shape, but often slightly compressed, as may be clearly seen in four models of tubal ova in the pronuclear stage, reconstructed at a magnification of 1000 diameters, in my possession. Depending on the plane of section, the diameter of a tubal ovum may thus vary to the extent of $5 \mu$ to $8 \mu$. The two nuclei in the preparation shown in A of figure 1, measure, the larger one, regarded as the female pronucleus, $23 \mu$ by $16 \mu$, the smaller $17 \mu$ by $15 \mu$. Essentially all of the chromatin is distributed over the linin network in fine granules, the larger nucleus presenting one large, faintly-
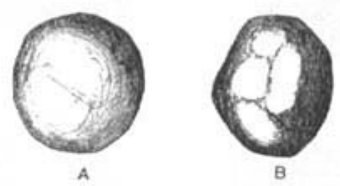

Fig. 2 Models, made after the Born method, of two tubal ova of the albino rat in the pronuclear stage. $\times 200$. A, rat No. 106, 24 hours; $B$, rat No. 110 , 24 hours, $15 \mathrm{~min}$. Reconstructions made at a magnification of 1000 diameters, figure reduced in reproduction.

staining chromatoid nucleolus. The ooplasm is finely granular, distributed so as to give the section a slightly mottled appearance. When compared with figures given by Sobotta and Burckhard (figs. 21 to 24, plates 9-10) showing pronuclear stages of the ova of the rat, my own seem to fall in about the middle of this series, thus some little time after their formation, but not immediately preceding the stage of segmentation spindle formation. In the albino rat, and perhaps in other mammals, the pronuclear stage, in its various phases of nuclear metamorphosis, must constitute a stage covering a relatively long period. If it is assumed that semination occurs about 10 to 12 hours after the beginning of insemination, such assumption being justified by the observations of Sobotta and Burckhard, according to whom the life of the spermatozoa in the genital tract of the white rat is only about 10 hours, and if it is recalled that in 
living rat ova Long found that the constriction of the second polar body may be completed three-fourths of an hour after its inception, then it must be evident that the pronuclear stage extends through a period which exceeds 10 to 12 hours, since in rone of my pronuclear stages obtained 24 hours after insemination was evidence of first segmentation spindle observed.

In order to determine accurately the relative position of the ova within the oviduct during the pronuclear stage and the stages of segmentation, oviducts containing ova were reconstructed after the Born wax plate method. In form, relations, and general structure, the oviduct of the albino rat is essentially the same as that of the mouse as described by Sobotta. The oviduct of the rat measures from fimbriated end to termination in the uterine horn from $2.5 \mathrm{~cm}$. to about $3.0 \mathrm{~cm}$. It presents eight to ten fairly constant major folds, the middle group of which is closely applied to the ovarian capsule. The upper or distal folds pierce the capsule, ending in the fimbriated end found within the capsule, while the lower or proximal folds, proximal with reference to the uterine horn, effect connection with the uterine horn. These relations are essentially the same as those described by Sobotta for the oviduct of the mouse. This observer recognizes four segments in the oviduct of the mouse, characterized by epithelial lining, nature and extent of folding of the mucosa, and thickness of the musculature. The first segment, which falls to the infundibulum, presents a thin musculature and high mucosal folds with epithelial lining consisting of relatively short cylindrical cells with distinct cuticular border and long cilia. As characteristic of this portion of the tube there are further described accessory nuclei compressed between the epithelial cells. Only this portion of the oviduct is ciliated. In the second segment, the lumen is large and the folds of the mucosa prominent. They are covered by a non-ciliated epithelium, without distinct cuticular border. The musculature is relatively thin. In the third segment the musculature is well developed with circularly and longitudinally disposed cells. The lumen is narrow and the folds are nearly absent, while the epithelium is of a simple columnar variety. The fourth segment, not so well characterized, consists of the loops which make con- 
nection with the uterine horns, with folds and epithelium much as in the third segment, and a prominent musculature. In all essentials, this description applies to the oviduct of the albino rat, except that in the first segment the accessory nuclei described by Sobotta as found between the epithelial cells were not evident in the rat. In figure 3, is reproduced a model of a wax reconstruction of the right oviduct of rat No. 106, killed 24 hours after the beginning of insemination, and containing eight ova in the pronuclear stage. This oviduct measured from fimbria to termination in the uterine horn $3.2 \mathrm{~cm}$. It presents 10 major folds, which folds may be recognized with more

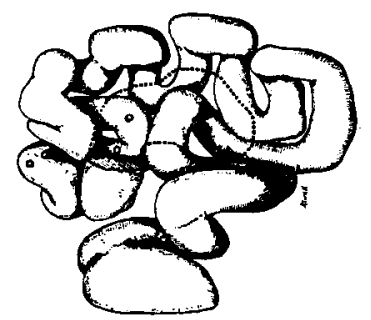

Fig. 3 Model of right oviduct of rat No. 106, 24 hours. $\times 10$. Fimbriated end and infundibulum removed in the drawing so as to expose underlying loops; their relative position given in dotted outline. The position of the ova, which are outlined in circles, is shown as if seen through a transparent wall. The relative position of three of the eight ova found within this tube cannot be revealed in this view of the model.

or less clearness in all the models made and here reproduced. The slight difference in the relative position of these folds as seen in the several figures may be accounted for by the varying degrees of tension to which the tissues were subjected prior to fixation. In rat No. 106, the ovaries with oviduct and upper end of the uterine horn, were excised and placed in the fixing fluid without applying any tension. Of these 10 major folds, the four distal ones, those beginning with the fimbriated end, fall to segments one and two of Sobotta's designation, having a wide lumen and folded mucosa. In the figure, the position of the ova is indicated by small black circles. By reason of the relation of the folds, only five of the eight ova can be brought 
to view in the aspect of the model sketched. The position of the first and the last of the series is correctly given. The ova are situated in a loop of the oviduct which is about $8 \mathrm{~mm}$. from the fimbriated end. By the end of the first day after the beginning of insemination, the ova have thus travelled about onefourth the length of the oviduct. In figure 4 is reproduced a model of a detailed reconstruction of that portion of the oviduct

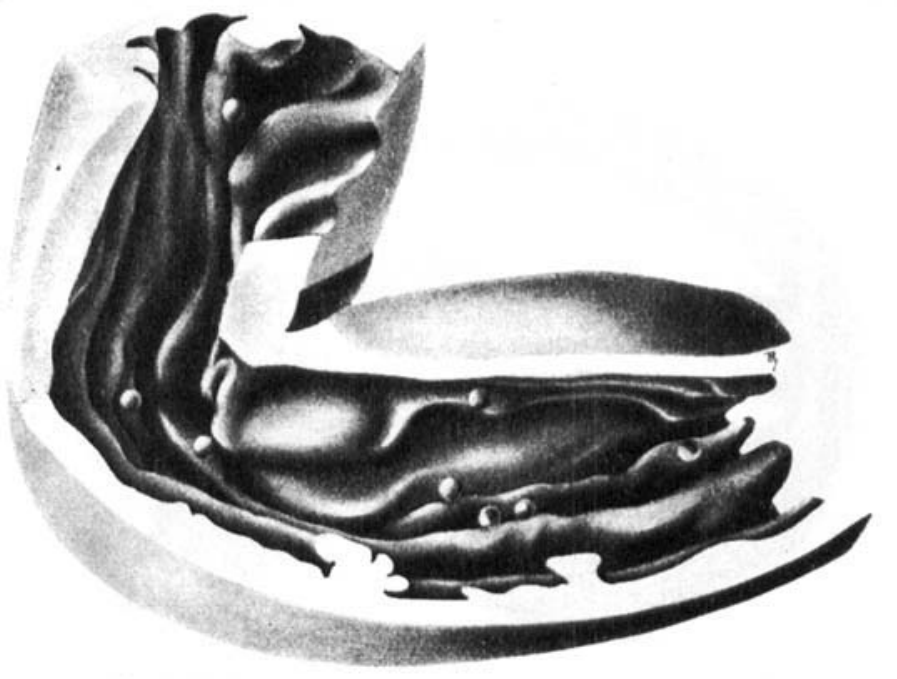

Fig. 4 Model of the segment of the right oviduct of rat No. 106, 24 hours, containing the ova the general position of which is shown in Figure $3 . \times 50$. The wall is in part removed, so as to expose the lumen. Note the character of the folds of the mucosa. The relative position of the eight contained ova, all in the pronuclear stage, is clearly shown.

containing the ova, representing a loop of the tube with one side cut away, this to show the extent and character of the mucosal folds, the width of the lumen and the relative position of the several ora. The figure presents these facts so clearly that lengthy description is deemed unnecessary. The several ova are distributed through a tube segment measuring about $2.5 \mathrm{~mm}$. in length. They lie free in the lumen, apparently bathed in a fluid from which there is only a small amount of precipitation at the time of fixation. Their position in the oviduct at 
this stage, free in the lumen, is well shown in figure 5, which is from a longitudinal section of a loop from the left oviduct of rat No. 109, showing three ova, with but few remaining discus cells and a thread of coagulum linking the ova together, an appearance quite characteristic at this stage. The figure was drawn by aid of camera lucida from a single section. All of the ova, of which there are seven, distributed through this loop, contain two pronuclei; in none of the ova figured do the two pronuclei

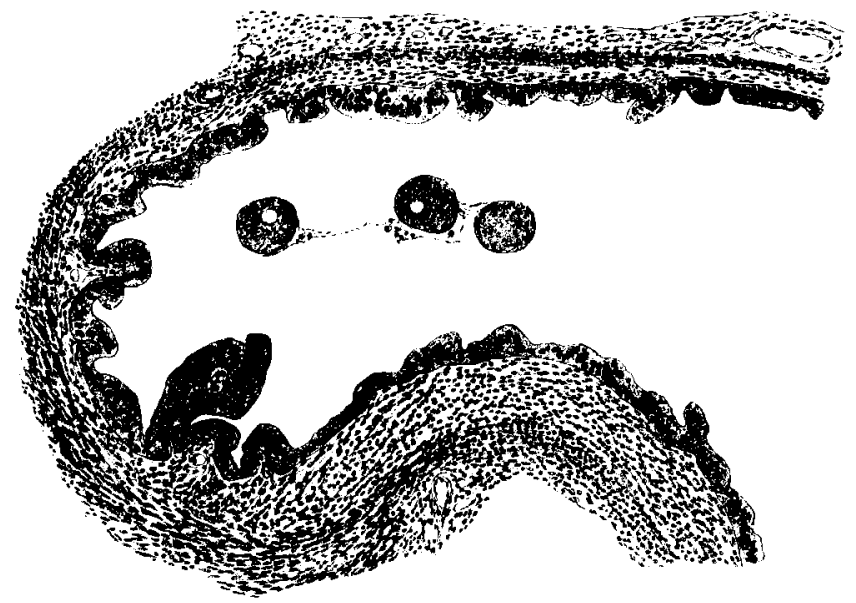

Fig. 5 Camera lucida drawing of a portion of a section of the left oviduct of rat No. 104, 24 hours, $15 \mathrm{~min} . \times 100$. Three ova with a few discus cells, are shown as lying free within the lumen. The ova are in the pronuclear stage, not shown in this section, but readily ascertained by tracing through the series. The loop of the oviduct here shown in section is cut longitudinally, thus the folds of the mucosa are not prominent.

fall in the same section. My series contains seven oviducts with pronuclear stages, with accompanying ovary, cut serially. Only one of the oviducts, rat No. 106, was reconstructed in wax. In the other six, graphic reconstructions were made. This permits analysing the loops, determines their sequence, but does not readily admit of measuring their length. In the six oviducts graphically reconstructed, the position of the ova, the number of which varies from one to seven in the several tubes, is essentially as in the wax reconstruction figured. It would appear, 
therefore, that in the albino rat, 24 hours after the beginning of insemination, the ova are to be found in the pronuclear stage, with the ova distributed in the end of the third to the beginning of the fourth major loop of the oviduct, a portion of the oviduct having a relatively wide lumen and lined by a much folded mucosa and possessing a relatively thin muscular wall, having thus migrated about one-fourth of the length of the oviduct.

\section{SEGMENTATION STAGES}

2-cell stage. The material on which my own observations of this stage are based is listed in table 2 .

TABLE 2

\begin{tabular}{|c|c|c|c|}
\hline RECORD NUMBER & $\begin{array}{l}\text { HOURS AFTER BEGINNING } \\
\text { OF INGEMINATION }\end{array}$ & NUMBER OF OVA & GTAGE OF DEVELOPMENT \\
\hline $\begin{array}{l}60 \\
59\end{array}$ & $\begin{array}{l}1 \text { day, } 18 \text { hours } \\
2 \text { days }\end{array}$ & $\begin{array}{l}7 \\
8\end{array}$ & $\begin{array}{l}\text { 2-cell stage } \\
\text { 2-cell stage }\end{array}$ \\
\hline 58 & 2 days, 17 hours & 8 & $\{$ 7, 2-cell stages; \\
\hline 61 & 2 days, 18 hours & 8 & 2-cell stage \\
\hline 62 & 2 days, 22 hours & 11 & $\left\{\begin{array}{l}10,2 \text {-cell stages; } \\
1,3 \text {-cell stage }\end{array}\right.$ \\
\hline
\end{tabular}

Thus in all 40 ova after the completion of the first segmentation division and 2 ova in the 3-cell stage, in each of which the undivided blastomere presents a nucleus in mitosis.

My own material lacks stages showing the formation of the first segmentation spindle, the conjugation of the two pronuclei, and the first segmentation division. I am forced to proceed from the pronuclear stage to that showing the first two blastomeres. It was not possible to supplement my material after this was sectioned and the stages determined, since it was only after leaving The Wistar Institute that this gap in my series was recognized. This is the more to be regretted since neither Melissinos, Sobotta and Burckhard, nor Kirkham and Burr, all of whom have considered maturation and fertilization as observed in the albino rat, discuss these stages in their account. In the albino rat. the fusion of the two pronuclei on the first segmentation 
spindle, and the first segmentation division would appear to fall to a period ranging from the beginning to near the middle of the second day after the beginning of insemination, probably about 30 to 32 hours after insemination. In the mouse, in which these stages have been very completely and carefully investigated by Sobotta, the conjugation of the pronuclei and the first segmentation spindle formation falls to the end of the first day after copulation. These phenomena appear to be passed through rather quickly in the mouse ovum, covering a period of only about one and a half to two hours.

The 2-cell stage with resting nuclei extends through a relatively long period. In the mouse it extends through nearly an entire day, as shown by Sobotta, who found 2-cell stages present through a period ranging from 25 hours to 48 hours after copulation. Melissinos often observed the 2-cell stage with resting nuclei in both mice and rats in material gathered 24 hours after copulation and to 44 hours thereafter. It is to be regretted that this observer does not differentiate more specifically between ova of mice and rats in his description. As a rule it is impossible to determine except by inference to which of the two varieties of ova his account refers. It may be assumed that the statements made apply equally well to the ova of either the mouse or the rat.

In my own material, the 2-cell stage was observed during a period extending from 1 day, 18 hours to 2 days, 22 hours after the beginning of insemination, thus for a period extending over more than 24 hours. In the albino rat, the first two blastomeres are equivalent cells of essentially the same size and structure, as may be seen from $B$ and $C$, of figure 1 , drawn respectively of ova found in the right and left oviducts of rat No. 59, killed two days after the beginning of insemination, and regarded as representative ova. The two cells of each ovum are not spherical, but of slightly oval form, with relatively large, distinctly membranated nuclei, with fine chromatin granules scattered on the linin network and a number of relatively large chromatoid nucleoli. The cytoplasm presents a granular appearance, the granules being evenly distributed throughout the cell. In my own material, I seldom find the two cells lying in the same plane, 
but one cell, as a rule, rises slightly higher than the other. This is more clearly seen in reconstructions than in sections. In figure 6 are shown reconstructions of the 2-cell stages, figured in $\mathrm{B}$ and $\mathrm{C}$ of figure 1 . In $\mathrm{B}$, of the figures, the plane of section is at right angles to the vertical axis of the reconstruction as shown in $\mathrm{B}$ of figure 6 , while in $\mathrm{C}$ of figure 1 , the plane of section is parallel to the vertical axis of the reconstruction shown in $A$ of figure 6. The equivalence or non-equivalence of the first two blastomeres of the segmenting mammalian ovum has been the subject of discussion since the time of Van Beneden's fundamental observations on the segmentation of the ovum of the rabbit. This discussion has been summarized a number of times in recent years, and need not be entered into here. Suffice to say that the consensus of opinion of the more recent contributors
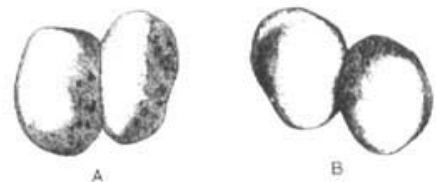

Fig. 6 Models, obtained by reconstruction after the Born method, of the 2-cell stages of the albino rat. Rat No. 59, 2 days. $\times 200$.

is, that the first two blastomeres of the mammalian ovum are equivalent in size and structure if the stage is observed soon after its formation. As above stated, the 2-cell stage of the mammalian ovum extends through a relatively long period, probably about 24 hours. The two cells do not as a rule divide synchronously, the division of one preceding the other by some little time, resulting in a 3-cell stage. The cell to divide first increases slightly in size and presents a clearer protoplasm prior to its division. In a 2-cell stage, viewed in this phase of cytomorphosis, one of the cells appears slightly larger with clearer protoplasm than does the other cell, explaining the difference in size and structure observed by Van Beneden and by other observers who concur in his views. I am convinced that a difference in the size of the two cells may be accounted for by the plane of section in which they are cut, even though the nuclei of both cells are included in the section. In the figures of sections of the 2-cell 
stage of the mouse, given by Sobotta and Melissinos, the nuclei of the two cells lie in about their center and essentially in the same plane. In my own material of the 2-cell stage of the albino rat it is not unusual to find the nuclei of the respective cells nearer the opposite poles of the two cells than at their centers, as shown in $\mathrm{C}$, of figure 1 . In $\mathrm{B}$ of this figure, where the two nuclei appear as lying much nearer the center of the cells, they are in reality placed much as in $\mathrm{C}$, as is shown by the reconstruction.

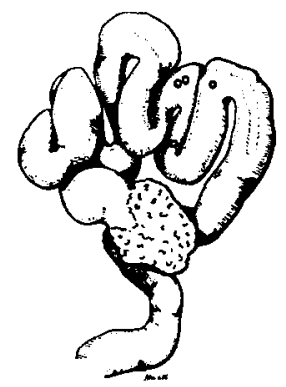

Fig. 7 Model of the right oviduct of rat No. 59, 2 days. $\times 10$. Not quite the entire oviduct was available for reconstruction, the upper end of the uterine horn thus not shown in the figure. The position of the four 2-cell stages, each of which is outlined in a circle, found within the tube, is shown as if seen through a transparent wall.

To determine the position of the segmented ovum in the 2-cell stage in the oviduct, reconstructions were made of two oviducts. In figure 7 is shown a reconstruction of the right oviduct of rat No. 59, killed two days after the beginning of insemination. In preparing the material for embedding, this oviduct was cut not quite at its insertion into the uterine horn. The portion of the oviduct reconstructed measures $2.29 \mathrm{~cm}$. Nine major loops are shown. The four ova in the 2-cell stage found in this tube are situated in the sixth to the seventh loop at a distance of about $1.4 \mathrm{~cm}$. from the fimbriated end. This portion of the oviduct falls to segment three of Sobotta's designation. It is lined by non-ciliated epithelium resting on a mucosa with inconspicuous secondary folds, but presenting four or five characteristic major folds. This portion of the oviduct is closely 
applied to the outside of the ovarian capsule, and conspicuous in all of the figures of models of the oviducts here presented. The detail of the distribution of the ova in the tube is given in figure 8 , a reconstruction under a higher magnification of the segment of the oviduct containing the ova. The lumen is exposed so that the character of the mucosal folds may be seen. The ova are spaced in a segment of the tube measuring $3 \mathrm{~mm}$., and are

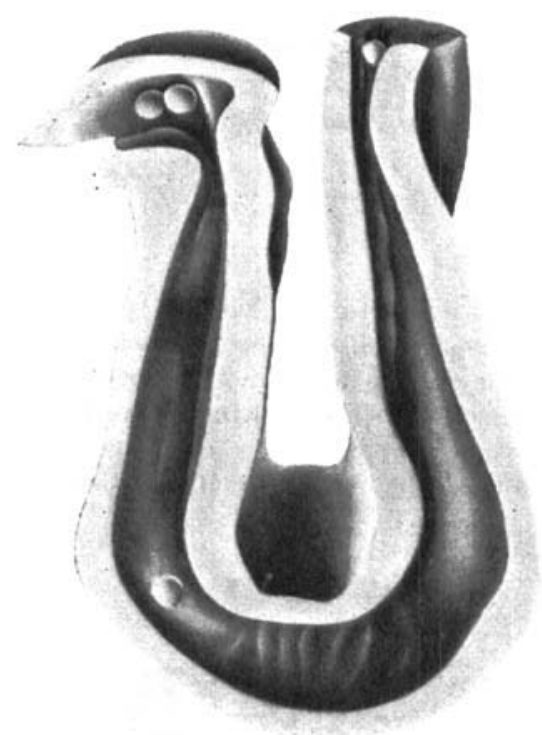

Fig. 8 Model of the segment of the right oviduct of rat No. 59, 2 days, containing the four 2-cell stages as shown in figure $7 . \times 50$. Note the absence of prominent folds in the mucosa. The segment presented in the reconstruction measures $3 \mathrm{~mm}$. The four 2-cell stages contained in this tube are relatively widely spaced.

in this case more widely separated than is usual for this stage. In figure 9, there is reproduced a reconstruction of the left oviduct of rat No. 62, killed 2 days, 22 hours after the beginning of insemination. This tube was also cut a little before its insertion into the uterine horn. The portion reconstructed measures $2.45 \mathrm{~cm}$. In it there are found five ova in the 2-cell stage, situated about $2 \mathrm{~cm}$. from the fimbriated end, and in the last loop of the third segment of the oviduct. The five ova are closely 
grouped between two opposing folds of the mucosa. Their general relations are shown in figure 10, a reconstruction under higher magnification of the segment of the oviduct containing

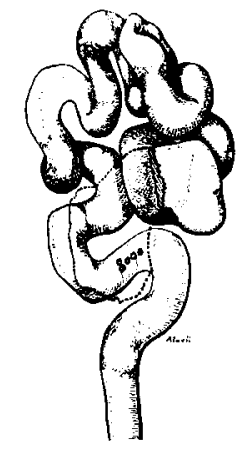

Fig. 9 Model of the left oviduct of rat No. 62, 2 days, 22 hour's. $\times 10$. Not quite the entire oviduct was available for reconstruction, thus the relative position of the upper end of the uterine horn is not shown in this figure. Fimbriated end and infundibulum removed in the drawing, so as to expose the underlying loops; their relative position is given in dotted outline. The position of five 2cell stages, found within this tube, is given as if seen through a transparent wall.

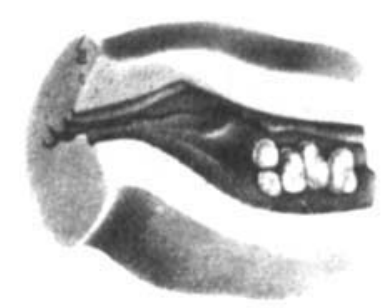

Fig. 10 Model of the segment of the left oviduct of rat No. 62, 2 days, 22 hours, containing the five 2-cell stages, the general position of which is shown in figure 9 . $\times 50$. Note the compact grouping of the ova.

the ora, cut so as to expose the lumen. At the magnification used it was not possible to reproduce in the model the exact shape of the several ova, their relative position is, however, correctly given. In all, ten oviducts, containing 40 ova in the 2-cell stage, are included in my series. Of these, two, as above given, were reconstructed by the Born method. The other eight were reconstructed graphically, beginning with the uterine 
end of the tubes. In six of these, the ova are quite closely grouped as given in the reconstructions shown in figures 9 and 10. In the remaining two they were more widely spaced, about as shown in figures 7 and 8 . In the oviducts taken from rats Nos. 58, 61, 62, killed respectively 2 days, 17 hours, 2 davs, 18 hours, and 2 days, 22 hours, after insemination, the ova are found in a portion of the tube which corresponds very closely to that shown in the reconstruction presented in figure 9 . In rat No. 60, killed 1 day, 18 hours after insemination, the ova are more widely spaced and are situated in a segment of the oviduct approximately one loop nearer the fimbriated end than that given in figure 7 , a model of the oviduct of rat No. 59, killed two days after insemination.

In one of the segmented ova of rat No. 60 , the two blastomeres resulting from the first segmentation division are distinctly separated by a space equal to about one-half of the diameter of each of the cells. No oolemma is discernible. The two separated cells appear normal in size, shape, and structure, as do also their nuclei. They lie free in a slightly distended portion of the lumen, and appear not to have been separated as a consequence of manipulation. The possibility of each developing separately is suggested, and may be offered as a possible explanation of the occurrence of very small embryos now and then found among others showing normal development. King states that "On dissecting pregnant females (rats) one frequently finds one or more embryos that are much smaller than the rest. While in some instances such small embryos appear normal and are presumably either runts or embryos that have resulted from superfecundation, in the majority of cases they are pathological, probably because of faulty implantation of the ovum." My own material contains pathologic ova and embryos in different stages of development. This portion of the material will be considered in Part II, where the possibility of the occurrence of half embryos will be discussed.

As may have been seen, the 2-cell stage of the albino rat covers a period of somewhat more than 24 hours, extending from about the middle of the second day until toward the end of the third 
day after the beginning of insemination. During this period the segmented ova migrate in the oviduct for a distance equaling nearly half its length. The trustworthiness of the material, it would seem to me, is shown by the fact that in the shorter time stages the segmented ova are situated nearer the fimbriated end, while in the longer time stages they approach the region of the insertion of the oviduct into the uterine horn. This is clearly shown in the reconstructions shown in figures 7 and 8 .

A 3-cell stage was observed only twice: in one of eight ova contained in the oviducts of rat No. 58 (2 days, 17 hours) and in one of eleven ova found in the oviducts of rat No. 62 (2 days,

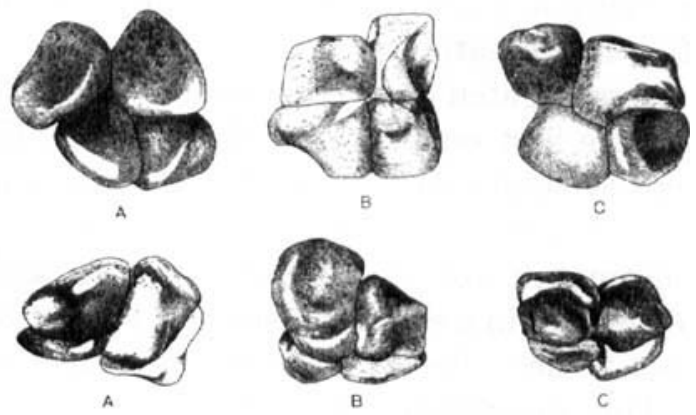

Fig. 11 Two views of each of three models of 4-cell stages of the albino rat. Rat No. 50, 3 days, 1 hour. $\times 200 . A, B$, and $C$, gives a side view, $A^{\prime}, B^{\prime}$, and $C^{\prime}$ a vertical view, of each of the three models.

22 hours). All the other ova found in these two animals were in the 2-cell stage. In the two 3-cell stages noted, the undivided blastomeres of each ovum presented a nucleus in mitosis; in one, in the monaster phase, in one, in the diaster phase. The division of the first two blastomeres, resulting in the 4-cell stage, it would appear, occurs in the albino rat toward the end of the third day. The material gathered at the beginning of the fourth day after insemination presents throughout a 4-cell stage. In $\mathrm{D}$ of figure 1 is shown reproduced one of the sections of a series of six sections including one of the ova in the 3-cell stage. Only one of the two cells resulting from the division of one of the first two blastomeres is included in the section; the cell in mitosis represents the undivided blastomere. 
4-cell slage. The material includes the oviducts of two rats, Nos. 50 and 63 , killed 3 days and 1 hour after the beginning of insemination, with twelve ova in the 4-cell stage. In figure 11, there are shown two views of each of the models obtained by reconstruction after the Born method, at a magnification of 1000 , of the three 4-cell stages found in the oviducts of rat No. 50. The drawing of the reconstructions do not present the conventional figures of the 4-cell stage of the mammalian egg. In none of the twelve ova of this stage was the plane of section such as to include all of the four cells in one section. Nearly all

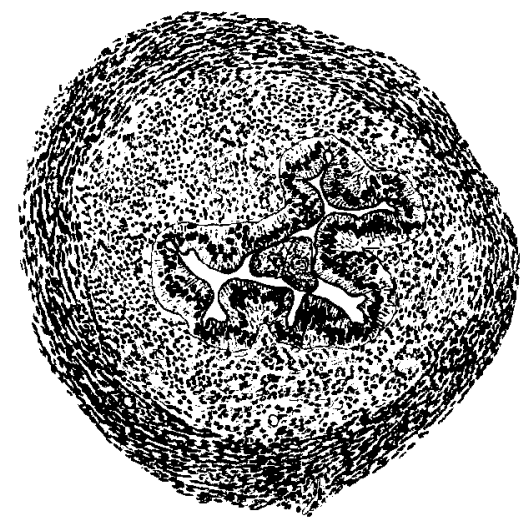

Fig. 12 Cross-section of right oviduct of rat No. 50, 3 days, 1 hour. $\times 100$. This section contains two cells of a 4-cell stage of the albino rat, slightly compressed between the folds of the tubal mucosa.

lie in a portion of the tube which presents a relatively narrow lumen, and appear as if slightly compressed between the folds of the mucosa. I am not disposed to regard this as a resultant of fixation, due to contraction at the time of fixation. In figure 12 is reproduced a cross section of the right oviduct of rat No. 50 , passing through a 4-cell stage. It is evident that in shape the two cells included in the section, conform in the main to the form of the lumen, the mucosa appearing as slightly retracted to one side of the egg mass. This conformity in shape of cell mass to the form of the lumen I find quite general in my material showing segmentation stages of the albino rat, to some extent 
even in the 2-cell stage, more clearly shown in the 4-cell and later segmentation stages, as will appear from further reconstructions presented. It would seem to me reasonable to assume that these cell masses are of such plasticity that they are molded by the tubal mucosa rather than they would compress the mucosa and maintain an inherent form. A number of segmented ova in presumably the 6- and 8-cell stages were removed from oviducts by injection and studied in warm normal salt solution, in a living state. In the warm normal salt solution the morula masses

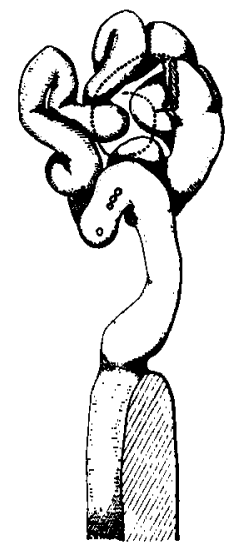

Fig. 13 Model of right oviduct of rat No. 50, 3 days, 1 hour. $\times 10$. A short segment of the upper end of the uterine horn, lower part of the figure, is included. The fimbriated end and a part of the infundibulum removed in the drawing so as to expose the underlying loops; their relative position is indicated in dotted outline. The position of the four ova in the 4-cell stage, at the beginning of the last loop of the oviduct, is shown as if seen through a transparent wall.

presented a nearly spherical form, conforming to the conventional illustrations of the same. In none of the sections of fixed material of my series was this the case. The form of the cell mass, assumed by the segmenting mammalian ovum in early stages of segmentation, therefore, seems to me a question more for academic discussion than one of fundamental importance. The right oviduct of rat No. 50 ( 3 days, 1 hour) was reconstructed after the Born method. This model is reproduced in figure 13, and includes the uppermost end of the uterine horn. The oviduct 
measures $2.8 \mathrm{~cm}$. and contains four ova in the 4-cell stage, situated at the beginning of the last loop leading to the uterine horn, $2.25 \mathrm{~cm}$. from the fimbriated end, thus in the fourth segment of the oviduct as of Sobotta's designation. In figure 14 is reproduced a detailed reconstruction of the segment of the oviduct containing the ova, with the convex portion of the wall of this loop, as shown in figure 13, removed. The section reproduced in figure 12, passes through the lower of the three upper ova, shown in reconstruction in figure 14. In the figure of the reconstruction as also in that of the section, is shown the groove in which these three ova lie. The other oviducts con-

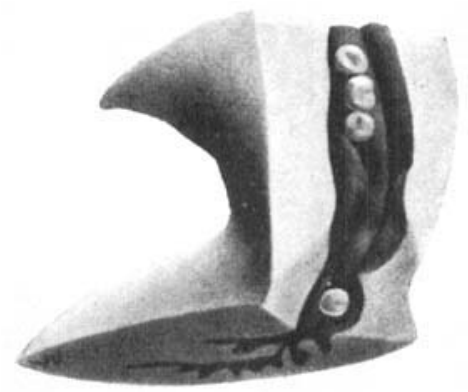

Fig. 14 Model of the segment of the right oviduct, rat No. 50, 3 days, 1 hour, containing the four ova in the 4-cell stage, the general position of which is shown in figure 13. The convex portion of the wall of the loop containing the ova is removed, so as to expose the lumen.

taining 4-cell stages were reconstructed graphically, beginning with the uterine end. The position of the ova in each is essentially as given in the model reproduced in figure 13.

8-cell stage. In rat No. 57, killed 3 days, 17 hours after the beginning of insemination, there are found in the left oviduct, six segmented ova in the 8-cell stage and one segmented ovum in the 11-cell stage. The right ovary and oviduct was injured in the process of embedding and could not be used for sectioning. The ova are spaced in the loop of the oviduct which terminates in the uterine horn. Six of the segmented ova were reconstructed, the seventh was not detected at the time the reconstructions were made. The six models obtained are reproduced 
in figure 15, two views of each model being shown. Five of the models, $\mathrm{A}$ to $\mathrm{E}$, show 8-cell stages. In $\mathrm{F}$, there is figured an 11-cell stage, three of the cells having completed the next following division. As may be seen from the figures, the form of these morula masses is not spherical but in the main slightly oval, with further irregularities better shown in the models than in the illustrations, due to the fact that the egg masses conform to the shape of the lumen of the oviduct in the region in which they are found. The mucosa lining the segment of this
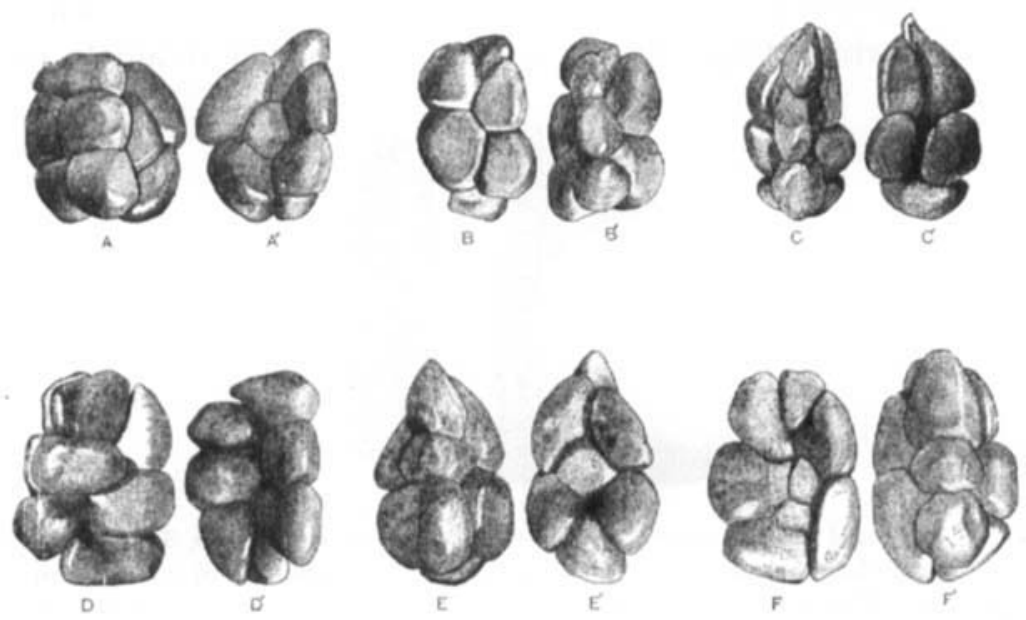

Fig. 15 Models, obtained by reconstruction after the Born method, of 8cell and 11-cell stages of the albino rat. Rat No. 57, 3 days, 17 hours. $\times 200$. Two views of each model is presented. A-A', to $\mathrm{E}, \mathrm{E}^{\prime}$ are of models of 8-cell stages; $F$ and $F^{\prime}$ of a model of a 11-cell stage.

oviduct containing the ova presents four quite regular longitudinal folds. In figure 16, there is presented a model of a detailed reconstruction of the segment of the oviduct containing the ova, their relative position in the tube and their relation to the major folds is clearly shown. One of these folds it was necessary to in part remove so as to bring to view in the drawing certain of the ova. In figure 17, there is reproduced a portion of one of the sections of the series from which the model shown in figure 16 was made. The fold of the mucosa occupying the center 


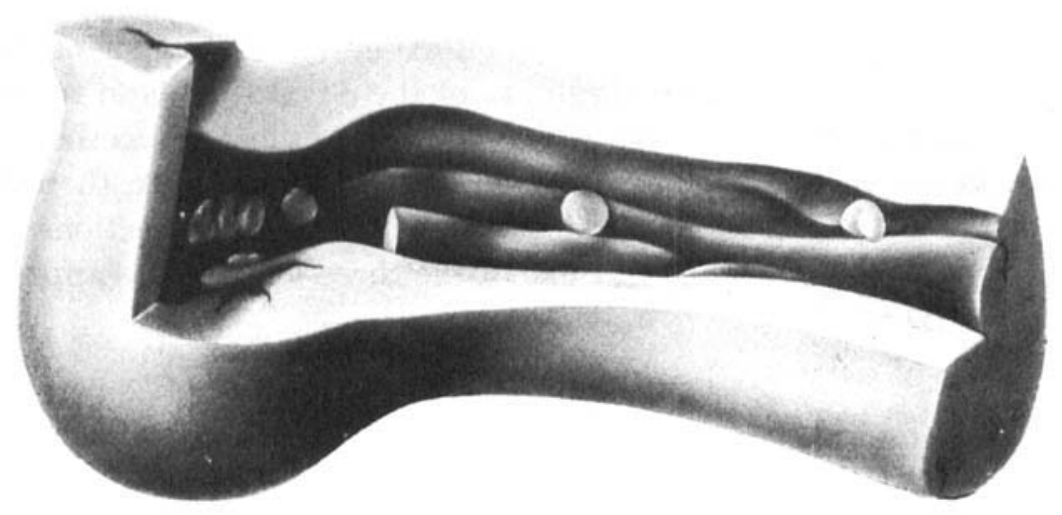

Fig. 10 Model of the segtnent of the oviduet, rat $\mathrm{No}, 57,3$ days, 17 bours, containing the ova shown in fig. $15 . \times 50$. A portion of the wall of the oviduct and a part of the major folds of the mutoen are removed in the drawing so as to expose the rontained ova. The relative position of the seven ova found in the tube is shown, as also the extent and chararter of the folds of the mucosa. The exact form of each of the several ova could not be reproduced in the model at the magnification used; their position is given correctly.

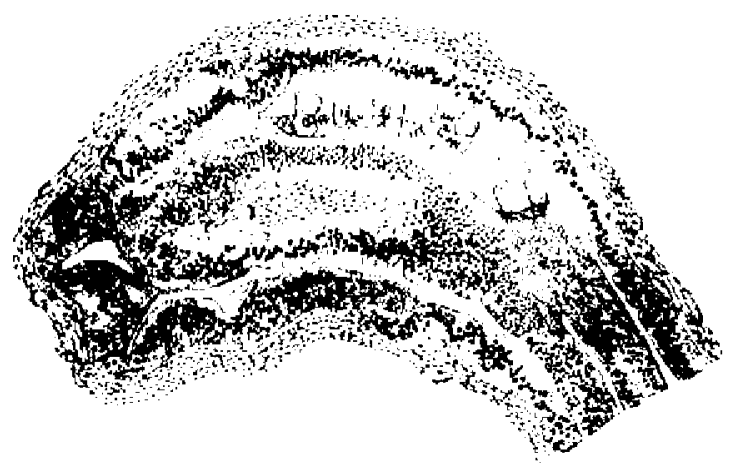

Fig. 17 Camers lucida drawing of $n$ portion of a section of the left oviduet of rat No. 57, 3 days, 17 hours. $\times 100$. This section is of the series of sections from which the models shown in figures 15 and 16 were made. Sections of four 8-cell atages, as seen in a single section, are included. The cloee proximity of three of these ova, their relation to the tubal wall and mucosal folds is to be noted. 
of the drawing, and greatly occluding the lumen, is the fold removed in the model. In this very fortunate section four of the morula masses are included; all are of the 8-cell stage and represent in section the four ova which are placed closely together as seen in the model figured in figure 16 . In figure $19, A$, there is reproduced at higher magnification another of the sections of the series, including the right one of the three ova in close apposi-

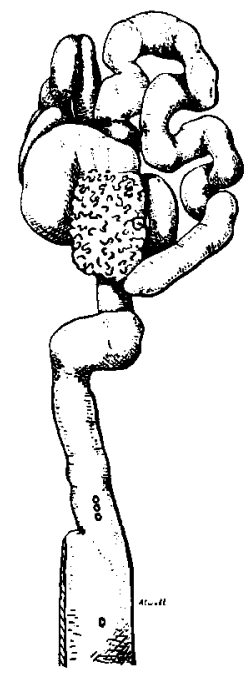

Fig. 18 Model of the left oviduct of rat No. 51, 4 days. $\times 10$. A short segment of the upper end of the uterine horn was included in the reconstruction, lower end of the figure. The position of three of the morula masses, 12-cell to 16-cell stages, in the terminal part of the oviduct is to be noted, a further one is located in the upper part of the uterine horn. These are shown as if seen through a transparent wall. A fifth morula, situated in the uterine horn about $1.5 \mathrm{~cm}$. from the entrance of the oviduct, is not included in the figure.

tion as seen in figure 17, showing six of the eight cells, each cut in the plane of its nucleus. In both of these figures (figs. 17 and 19) the morula masses, as seen in the sections drawn, present a quite regular oval outline. In succeeding sections, in which the mucosal fold and the wall of the oviduct approximate, the cross diameter of each of the four morula masses becomes greatly reduced, they appearing in the final sections of the series in which they are included. as narrow, non-nucleated bands of protoplasm. 
This series, it seems to me, corroborates the statement previously made, that the detail of form of the living segmenting ova of certain mammals, while in transit through the oviduct, is in a great measure dependent on the configuration presented by the lumen of the oviduct in the particular region in which they are found.

12-cell to 16-cell stages. Rat No. 51, killed 4 days after the beginning of insemination, presents the end of the segmentation stages in the oviduct. In the genital tract of this animal there were found eight morula masses, five on the left side and three on

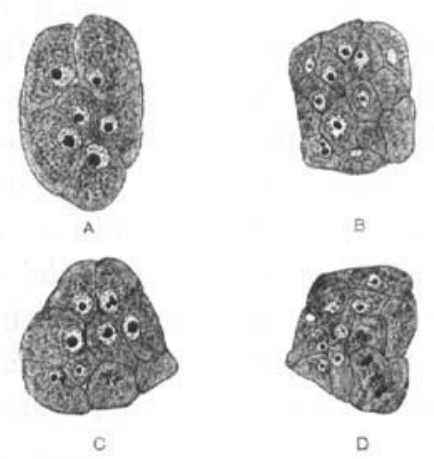

Fig. 19 Sections of morula stages of the albino rat. $\times 200 . \quad$ A, 8-cell stage, rat No. 57, 3 days, 17 hours; six of the eight cells, each cut in the plane of its nucleus, are included in the section figured. B, C, and D, 12-cell to 16-cell stages, from right oviduct, rat No. 51,4 days.

the right side. It is somewhat difficult to determine definitely the number of cells constituting each of the morula. The number appears to vary between 12 and 18 , though nearly all of the morula masses show certain nuclei in mitosis. The left oviduct with a short adjoining segment of the uterine horn was reconstructed. Slight tension was applied to the tissue prior to fixation, which accounts for the elongation of the proximat loop of the oviduct. The model is reproduced in figure 18. As is evident on study of this figure, three of the morula masses are situated in a portion of the oviduct just prior to its insertion in the uterine tube. These are closely grouped between folds of the mucosa. A fourth morula is found in the uppermost part of the uterine 
cavity, just distal to the opening of the oviduct, lying free in a slightly distended portion of the lumen. This morula is of irregular discoidal form, presenting an appearance which suggests that it was fixed soon after it escaped from the oviduct. A fifth morula, of regular oval form, comprising very probably 18 cells, all of which present resting nuclei, is lodged in a shallow pit of the uterine mucosa a little over $1 \mathrm{~cm}$. from the tubal opening. This portion of the uterine horn was not included in the reconstruction, the position of this morula is not, therefore, indicated in the figure. It is evident that this tube was fixed while the several morula masses were in transit from the oviduct to the uterine horn, which occurs, to judge from the material at my disposal, at the end of the fourth day after the beginning of insemination. The morula masses of the right tube are situated in the oviduct just before its point of insertion into the uterine horn, in about the same relative position as are the three upper morula masses of the left side, as shown in the reconstruction. They are of discoidal form, in close relation and appear to comprise, the one 12 , the other two 14 to 16 cells. In $\mathrm{B}, \mathrm{C}$ and $\mathrm{D}$ of figure 19 are reproduced sections of each of these three morula stages. The figures, however, are delusive in that the section for each passes through the greatest diameters of the respective morula.

The material at hand permits the conclusion that in the albino rat the segmenting ova pass from the oviduct to the uterine horn at the end of the fourth day after the beginning of insemination, probably in the 12-cell to 16-cell stages. With the beginning of the fifth day, as will appear from further discussion, all of the ova are to be found in the uterine horn.

\section{SUMMARY OF SEGMENTATION STAGES, RATE, AND VOLUME CHANGES}

The following summary of the data (table 3 ) gained by a study of the models of oviducts containing ova in stages from the pronuclear to 12-cell to 16-cell stages in which latter stage transit to the uterine horn occurs, is presented to indicate rate of transit within the oviduct. The regularity of the rate of transit 
as revealed in the summary may perhaps speak for the trustworthiness of the age data as concerns my material.

It will be observed that the ova approach the uterine end of the oviduct while in the 2-cell stage; transit through the last portion of the oviduct, where the greater part of the segmentation occurs, being relatively slow. It is hoped that these data, for the accuracy of which I am dependent on reconstructions, may be of service to others who may desire to collect segmentation stages of the albino rat.

TABLE 3

\begin{tabular}{|c|c|c|c|c|c|c|c|}
\hline $\begin{array}{l}\text { RECORD } \\
\text { NUMBER }\end{array}$ & $\begin{array}{l}\text { BIDE RECON. } \\
\text { STRUCTED }\end{array}$ & $\mathbf{A G E}$ & $\begin{array}{c}\text { NUMBER } \\
\text { OF OVA }\end{array}$ & STAGE & $\begin{array}{l}\text { LENGTH OF } \\
\text { OVIDCOT }\end{array}$ & $\begin{array}{l}\text { DISTANCE } \\
\text { OF OVA } \\
\text { PROM FIM- } \\
\text { BRIA }\end{array}$ & \begin{tabular}{|c} 
RELATIVE \\
LENGTH OF \\
TUBE \\
TRAVERBED
\end{tabular} \\
\hline & & & & & cm. & $\mathrm{cm}$. & \\
\hline 106 & $\begin{array}{l}\mathbf{R} \\
\mathbf{P}\end{array}$ & 1 day & $\begin{array}{l}8 \\
4\end{array}$ & pronuciear & $\begin{array}{l}3.2 \\
2.29 *\end{array}$ & 0.8 & 0.25 \\
\hline $\begin{array}{l}59 \\
62\end{array}$ & $\begin{array}{l}\pi \\
\mathrm{L}\end{array}$ & 2 days & 5 & 2-cell & $\begin{array}{l}2.29^{*} \\
2.45^{*}\end{array}$ & $\begin{array}{l}1.4 \\
2.0\end{array}$ & 0.82 \\
\hline & & 22 hrs. & & & & & \\
\hline 50 & $\mathbf{R}$ & $\begin{array}{l}3 \text { days, } \\
1 \mathrm{hr} .\end{array}$ & 4 & 4-cell & 2.8 & 2.5 & 0.90 \\
\hline 51 & L & 4 days & 5 & $\begin{array}{l}\text { 12- to } 16- \\
\text { cell }\end{array}$ & 2.86 & 2.86 & 1.00 \\
\hline
\end{tabular}

${ }^{*}$ Not the entire length of oviduct was available for reconstruction.

In order to obtain the volume changes of the ova during transit through the oviduct, beginning with the pronuclear to 8-cell to 11-cell stages, the following procedure was adopted. As has been shown by my figures, reconstructions were made at a magnification of 1000 diameters of ova presenting the stage in question. The sections of my series measure $10 \mu$ in thickness. In order, therefore, to obtain the correct third dimension, it was necessary to use wax plates $10 \mathrm{~mm}$. thick, in actual practice, five superimposed $2 \mathrm{~mm}$. plates. For the majority of the sections of my series this procedure was relatively simple. However, there was usually a question as to the thickness to be ascribed to the first and last section of any given series, since it was evident, both from the appearance of the section, as seen under the magnification used, and the appearance of the model, that the end sections did not measure $10 \mu$ in thickness, and it 
was necessary to reduce proportionately the thickness of the wax plate representing them. As a rule, these were made about one-half the thickness of the other plates. The irregularities revealed by the rough model after superimposing the respective plates, not so marked as might be supposed considering the thickness of the plates used, were adjusted, not by trimming the model and cutting away wax, but by smoothing with warm irons. The possibility of error is admitted, but since all of the models were made in the same way, errors if committed were probably essentially the same for all of the models. The volumes of the models were obtained by weighing the water displaced by each, and after making the necessary temperature corrections, reducing weight of water displaced to volume. The average of several determinations is given in table 4 .

TABI.E 4

\begin{tabular}{|c|c|c|c|c|}
\hline AECORD NUMBER & AGE & STAGE & $\begin{array}{l}\text { ACTUAL VOL. } \\
\text { OF EGG MASS } \\
\text { IN C. MM. }\end{array}$ & $\begin{array}{l}\text { AVERAGE VOL. } \\
\text { PEH ATAGE GIVEN } \\
\text { IN C. MM. }\end{array}$ \\
\hline 106 & 1 day & pronuclear & 0.00015058 & \\
\hline 106 & $1 \mathrm{day}$ & pronuclear & 0.00014317 & \\
\hline 106 & 1 day & pronuclear & 0.00015775 & \\
\hline 106 & $1 \mathrm{day}$ & pronuclear & 0.00017127 & 0.000155693 \\
\hline 59 & 2 days & 2-cell stage & 0.00016240 & \\
\hline 59 & 2 days & 2-cell stage & 0.00018273 & 0.000172565 \\
\hline 50 & 3 days, $1 \mathrm{hr}$. & 4-cell stage & 0.00018338 & \\
\hline 50 & 3 days, $1 \mathrm{hr}$. & 4-cell stage & 0.00015520 & 0.000162443 \\
\hline 57 & 3 days, 17 hrs. & 8-cell stage & 0.00018893 & \\
\hline 57 & 3 days, 17 hrs. & 8-cell stage & 0.00016040 & \\
\hline 57 & 3 days, 17 hrs. & 8-cell stage & 0.00018653 & \\
\hline 57 & 3 days, 17 hrs. & 8-cell stage & 0.00018193 & \\
\hline 57 & 3 days, 17 hrs. & 8-cell stage & 0.00019979 & 0.000183516 \\
\hline 57 & 3 days, 17 hrs. & 11-cell stage & 0.00021025 & 0.00021025 \\
\hline
\end{tabular}

The uniformity of the figures giving the actual volume of the egg mass, as determined by the weight of the water displaced by the models of the respective ova reconstructed, leads me to feel that the errors committed in reconstruction were not serious. The last column of the table, giving averages, is of interest since it shows a very slight increase in the volume of the egg mass during segmentation and transit through the oviduct. Following the pronuclear stage, which, as has been seen, ex- 
tends through a relatively long period and into the beginning of the second day, by which time the ova have migrated about onefourth of the length of the oviduct, there occur only three successive mitotic divisions, including the first segmentation division, namely mitoses resulting in 2-cell, 4-cell and 8-cell stages while the ova are in transit in the oviduct. In making this statement it is assumed that in the successive segmentations, the several cells divide synchronously, which is not in conformity with the fact. These three mitotic divisions are spaced at intervals of about 18 hours. In the next following division, the fourth, the ovum passes from the oviduct to the uterine horn. Since the normal gestation period of the non-lactating albino rat is only 21 to 23 days, this slow rate of increase in volume and multiplication of cells during the first four days of development is of especial interest and is very probably to be accounted for by the inadequacy of the food supply of the ovum during its transit through the oviduct.

The presence or absence of the oolemma has not been considered in discussing the segmentation stages of the albino rat. In my own material, the oolemma was clearly observed in certain of the 2-cell stages, but not in the 4-cell nor 8-cell stages. Widakowich reports that he has observed in the albino rat, loss of the oolemma even in the 2-cell stage. Since all of the material covering these stages was fixed in Carnoy's fluid, a fluid with a relatively large glacial acetic acid content, it may be questioned as to whether the fixative used may not be in part responsible for the early disappearance of the oolemma, though neither Hubrecht nor Sobotta considers the presence or absence of an acid in the conserving fluid of special moment in the fixation of the oolemma. Sobotta finds that the oolemma disappears in the ova of mice during the 8-cell stage. The early disappearance of the oolemma in the albino rat may be offered as an explanation of the fact that the egg mass during segmentation and transit through the oviduct does not, as a rule, present a spherical form but appears compressed and molded to fit the form of the lumen. A similar explanation is offered by Sobotta to account for the irregularity of form assumed by the ovum of the mouse after loss of the oolemma. In the forms in which the oolemma 
persists through the later stages of segmentation, as for instance in the rabbit, the morula mass presents a spherical form. The transit of the ova through the oviducts is effected, very probably, through peristaltic action of the muscular coat, since only a relatively short portion is lined by ciliated epithelium. Whether or not there exists a rhythmic periodicity in the peristaltic action, it is impossible to state. The fairly regular rate of transit argues for the presence of some regulatory mechanism. The compact grouping often presented by a series of ova in transit through the oviduct, especially after reaching the portion with narrower lumen, suggests peristaltic action.

The literature dealing with the segmentation stages of the albino rat is very meagre. Grosser figures what is presumably an 8-cell stage. His figure 27 is referred to only incidentally in the text, but in the accompanying legend it is stated that the figure shows "three ova of the white rat in process of segmentation, with zona pellucida, in transit through oviduct, three and one-half days after insemination." If I am right in interpreting these ova as in the 8-cell stage, this corresponds very closely to my own observation on rat No. 57, 3 days, 17 hours (figs. 15-17). It is impossible to draw definite conclusions as to the segmentation of the ova of rats from the account of Melissinos. This observer while he states that his material includes the ova of mice and rats, and while considering segmentation mentions the ova of both forms, discusses them without differentiating between the two. His figures all refer to ova of the mouse. Selenka, Robinson, and Widakowich, who have contributed to our knowledge of the embryology of the albino rat, do not include the segmentation stages, to be found in the oviduct, in their account.

The rate of segmentation and the time of transit through the oviduct, as given in the literature for certain other mammals is as follows: Sobotta has shown for the mouse that the 2-cell stage is reached about 24 hours after copulation, the ovum remaining in this stage to about the 48th hour. The 4-cell stage was observed at about 50 hours, the 8-cell stage at 60 hours, and the 16-cell stage at 72 hours 'post coitum.' The ova of the mouse pass into the uterine horn about 80 hours post coitum, 
thus the beginning of the fourth day, in a stage in which 16 cells up to 32 cells may be enumerated; the oolemma having been lost in the 8-cell stage. The data furnished by Melissinos as concerns the mouse, are as follows: The 2-cell stage is obtained at the end of 24 hours after copulation, the 6-cell stage during the first 12 hours of the second day, and the 28-cell stage during the second 12 hours of the second day. The ovum is said to pass into the uterine horn at the end of the third day after copulation, retaining its oolemma. The account of Sobotta seems the more reliable. Hensen describes a 2-cell stage in the guineapig 22 to 24 hours after copulation, and Bischoff records that the ovum of the guinea-pig passes into the uterine horn while in the 8-cell to 16-cell stage, toward the end of the third day. Heape, who has described very fully the segmentation stages of the mole (Talpa europea) gives no data as to the rate of segmentation. In the explanation of the figures presented it may be noted that the ova figured, showing 2-cell to 15-cell stages, were taken from the oviduct. His figure 20 , showing an ovum 'fully segmented' was obtained from the anterior end of the uterus. Assheton gives for the rabbit the following data: The 2-cell stage is obtained about 24 hours and the 4-cell stage about 26 hours after coitus. The third series of divisions begins about 28 hours after coitus, so that by the end of the second day a typical morula of 16 cells to 20 cells is to be found. Between 73 hours and 96 hours the beginning of the blastodermic vesicle formation is to be noted. Ova obtained 80 hours after coitus, still surrounded by the oolemma, were removed from the uterine horn. Data as to the relative position of the ova in the oviduct in the several stages of development discussed, are given. As concerns the sheep, Assheton states that the ova pass into the uterine horn early on the third day after mating. The pronuclear stage is to be observed the second day, and the first segmentation at the end of the second day. By the fourth day, with the ova in the 8-cell stage, they are found in the upper end of the uterine horn. The blastodermic vesicle formation begins with the 16-cell stage. Again, according to Assheton, the ova of the pig pass to the uterus about the third day after fertilization, if I read him rightly, reaching the uterus in the 4-cell stage, although ova in the 2-cell 
and 3-cell stages were obtained from the upper end of the uterine horn. The presence of 2-cell stages in the uterine horn has also been noted by Keibel, in Erinaceus europaeus, by Van Beneden in the bat, and by Hubrecht in the insectivor Tupaya javanica. Finally, it may be noted that according to the observations of Bischoff, the segmenting ovum of the dog occupies 8 to 10 days after insemination in transit through the oviduct.

\section{COMPLETION OF SEGMENTATION AND BLASTODERMIC VESICLE FORMATION}

The material covering the end stages of segmentation and the early stages of blastodermic vesicle formation is listed in table 5 .

\begin{tabular}{|c|c|c|c|}
\hline \multicolumn{4}{|r|}{ TABLE 5} \\
\hline $\begin{array}{l}\text { RECORD } \\
\text { NUMBER }\end{array}$ & $A G E$ & $\begin{array}{c}\text { NUM- } \\
\text { BER OB } \\
\text { OVA }\end{array}$ & $\operatorname{STAGE}$ \\
\hline 64 & 4 days, $14 \mathrm{hrs}$ & 5 & Early stage of blastodermic vesicle formation \\
\hline 52 & 4 days, 15 hrs & 8 & $\begin{array}{l}\text { Morula, beginning of segmentation cavity, early } \\
\text { stage of blastodermic vesicle }\end{array}$ \\
\hline 55 & 4 days, $16 \mathrm{hrs}$. & 1 & Early stage of blastodermic vesicle \\
\hline 68 & 4 days, 16 hrs. & 4 & Early stage of blastodermic vesicle \\
\hline 53 & 5 days & 7 & Early stage of blastodermic vesicle \\
\hline 56 & 5 days & 5 & Fiarly stage of blastodermic vesicle \\
\hline
\end{tabular}

Thus there are at hand 30 ova, showing late morula stages, the beginning of segmentation cavity formation and early stages of the blastodermic vesicle, falling in the latter half of the fifth day after the beginning of insemination. In all of the uteri from which this material was taken, the ova are spaced in the uterine horns about as in later stages of development; they lie free in the uterine lumen, are in the main ovoid in form, their long axis presenting no definite relation to the long axis of the uterine horn. In preparing this material for sectioning, it was the custom to cut an entire uterine horn into segments measuring about $1.0 \mathrm{~cm}$. to $1.5 \mathrm{~cm}$. in length. These segments were then embedded so as to admit cutting longitudinally and in a plane parallel to the plane of the mesometrium. Cut in this way, the majority of the ova were cut longitudinally or nearly so, others in an oblique plane, others again, crosswise. Since it 
is impossible to orient the ova prior to sectioning, the securing of desirable sections is a matter of chance. The difficulty is further enhanced by reason of the fact that owing to shrinkage as a result of the action of the fixing fluid, the ova in the vesicle stage are apt to be more or less folded, so that even though the plane of section may be that desired, the resultant sections lose in value by reason of this folding.

It has been shown that in the albino rat, the ova pass from the oviduct to the uterine horn toward the end of the fourth day. During the first half of the fifth day, the migration of the ova from the oviduct to the uterine horn appears to be completed, so that by the second half of the fifth day the ova are spaced in the uterine horn about as after fixation to the uterine mucosa. As to the factor or factors which play a rôle in the descent of the ova through the uterine horn and their fairly regular spacing, my own material gives no data; these changes occurring, apparently, during the first half of the fifth day, covering which my material is lacking. Widakowich, who has given especial study to these questions, presents the following considerations: In the downward migration of the ova in the uterine horn, it cannot be assumed that the ova are capable of active movement nor can their motion be ascribed to the action of gravity. While peristaltic action may play a part, it is difficult to see how peristalsis could be so regulated as to space the ova fairly regularly within the uterine cavity. The presence of a ciliated epithelium in the human uterine cavity during the intermenstrual period suggested the presence of a ciliated epithelium in the uterine horn of the rat. After many preparations had been searched in vain for its presence, Widakowich found short cilia, not more than $2 \mu$ long in the epithelium lining the uterine cavity of a rat killed four days after copulation, and containing ova in the blastodermic vesicle stage. It would appear, therefore, that the uterine epithelium of the rat presents a ciliary border for only a relatively short time, and that the transportation of the ova within the uterus is effected by the cilia. Mandl also found, his material however not including the rat, that cilia are present in many animals on the epithelium lining the uterus only at certain periods, and perhaps only relatively 
short periods. While the presence of cilia may explain the migration of the ova in the uterine tube, Widakowich can offer no conclusions as concerns the regulatory mechanism by means of which the ova are spaced at fairly regular intervals in the lumen of the uterus. In none of my sections of the uteri of albino rats, obtained during the fifth day after insemination, have $I$ been able to note the presence of cilia on the uterine epithelium, even when sections were studied under the oil immersion. After reading the account of Widakowich, their presence was looked for in all pertinent stages, but without success. Especially in rat No. 50, in which the ova were passing from the oviduct to the uterine horn was careful search made, but nothing like a distinct ciliary border, composed even of short cilia, was ascertained. In the left genital tract of this rat, as has been stated. three ova were found in the terminal part of the uterine end of the oviduct, one in the uterine lumen just distal to the mouth of the oviduct and one a little over a centimeter from this opening. The latter was lodged in a shallow depression of the uterine mucosa, as is characteristic for stages lying free in the lumen. The question as to whether this ovum was permanently lodged is difficult to answer. If this is assumed, it is further necessary to assume that the other ova would need to pass it to reach the more distal parts of the uterine lumen.

The literature contains no definite statements as concerns the reactions of the epithelium and mucosa of the uterus to the ova soon after their appearance in the uterine cavity. Widakowich summarizes the views by stating that "It is generally stated, that so long as the ova lie free, the uterus shows no changes." He himself notes that at this time the mucosa presents evidence of marked new formation of capillaries. Burckhard, who had at his disposal a large number of stages showing implantation of the ovum of the mouse, discusses at length the appearance presented by the uterus soon after the ova enter the same and the lodgment of the ova therein. This observer notes that in the non-gravid uterus of the mouse, the lumen lies more or less eccentric, and towards the mesometrial border. 
The lumen is not srnooth, but presents numerous radially arranged folds, certain of which are relatively deep. Essentially the same characteristics pertain to the mucosa of the uterus, soon after the beginning of gravidity. As the ova pass from the oviduct to the lumen of the uterus they become lodged in certain of the mucosal folds, and generally in certain of the deeper ones to be found along the anti-mesometrial border. I find Burckhard's account of the form of the lumen of the uterine horn, of the structure of the mucosa in early stages of gravidity, and the lodgment of the ova, pertaining to the mouse, applies equally well to the albino rat. No reason can as yet be given as to why the ova are lodged in the mucosal folds in which they are found, and not in others. So far as may be ascertained from the sections, the particular mucosal folds in which the ova are found, do not differ in form and structure from neighboring folds. It is possible that by reconstruction of the epithelial lining of the entire uterine horn in pertinent stages, certain characteristies of form and position might be revealed as possessed by certain mucosal folds which make them especially favorable for the lodgment of the descending ova. Such reconstructions, however, have not been made. Burckhard states that in the mouse, about the middle of the fifth day, after the ova have been in the uterine cavity for a number of hours, there may be observed the first changes in the uterine wall. The changes consist primarily in a flattening of the uterine epithelium. In the immediate region where implantation is to occur, the lining epithelial cells present instead of a cylindric form, a cubic form. The area is sharply demarked from the surrounding epithelium, the transition of cubic to cylindric epithelium being marked by a sharp-lipped epithelial ledge. In my own material of the rat covering these stages, the uterine mucosa likewise presents shallow pits, in the immediate regions where the ova are lodged, lined by slightly flattened, cubic epithelium, very much as described by Burckhard for the mouse. Widakowich presents an excellent figure (fig. 2 of his contribution, rat four days after fertilization-'Befruchtung') showing clearly the relations of the ova to the uterine wall. In this rat, the 
uterine epithelium presented a ciliary border, present even in the shallow pit lodging the ovum sketched. He argues from this that the shallow depression and the flattening of the epithelium are not a result of pressure exerted by the vesicle, as thought by Sobotta and Melissinos, but must be due to an active change in the epithelium itself. The mucosa underlying the shallow pits presents at this stage no change of structure. I am thus in accord with Widakowich when he states that he was not able to observe in the mucosa of the rat in the early stages of gravidity, the giant cells described by Disse as found in the uterine mucosa of Arvicola arvilis, in similar stages.

The form presented by the ova of the albino rat, in the late morula stages and the early stages of blastodermic vesicle, is ovoid, as may be seen from the figures to be presented. Widakowich is inclined to believe that the form of the blastodermic vesicle of the rat is in a measure dependent on the general form of the space in which it is lodged. He figures two vesicles (figs. 1-2) one of which is nearly spherical, the other of distinctly oval form. Duval (figs. 73-83) presents vesicles having ovoid, triangular, and spherical forms. Christiani's figures covering these stages, are too schematic to be of any value in drawing conclusions. I fear Robinson's account is based on imperfectly fixed material. He states that "toward the end of the fifth day, or the commencement of the sixth day, the longitudinal axis of the blastodermic vesicle is $125 \mu$ long. During the sixth day, that axis is diminished, first to $95 \mu$, and then to $64 \mu$, after which it again increases, and at the commencement of the seventh day, it is $121 \mu . "$ Neither Fraser nor Selenka describes nor figures the stages here considered. In the mouse, according to the accounts of Melissinos, Burckhard, and Sobotta, the form of the blastodermic vesicle in early stages is spherical.

The more specific consideration of my own material I shall introduce with a discussion of three stages taken from the uterus of rat No. 52, killed 4 days, 15 hours after the beginning of insemination. In $A$, of figure 20 , there is reproduced the middle one of seven sections of a late morula stage. This morula is of ovoid form, measuring $85 \mu$ in its long diameter, $54 \mu$ in its 
broad diameter-that is, in plane of sections, and since it passes through seven sections of 10 thickness, measures approximately $70 \mu$ in its third dimension. It consists of 24 cells, as estimated by counting the nuclei contained in its sereral sections. The cells vary in size as well as in shape. The nuclei are for the main of spherical form, presenting one or several large nucleoli and fine chromatin granules. This morula is found within a fold of the mucosa, each side of which presents a slight depression, lined by slightly flattened epithelium. This morula mass lies

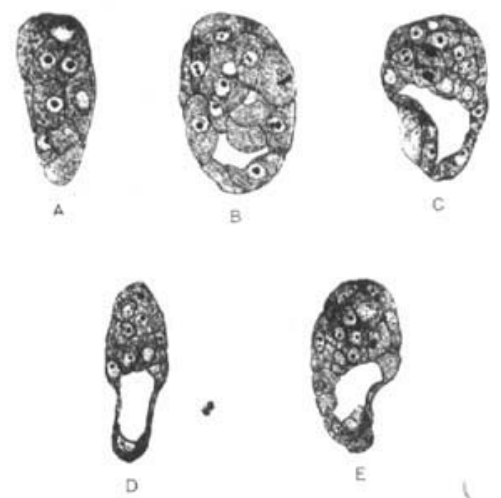

Fig. 20 Sections of morula mass and carly stages of blastodermic vesicle of the albino rat. $\times 200 . A, B, C$, rat No. 52,4 days and 15 hours. $D$ and $E$, rat No. 684 days and 16 hours. A, late stage of morula; $B$, shows the very beginning of the formation of the segmentation cavity; C, D, E, early stages of blastodermic vesicle, in $\mathrm{E}$, a distinct covering layer in the thicker portion or floor of the vesicle is evident.

free in the lumen of the mucosal fold, and not in contact with the uterine epithelium. The outline and extent of the shallow depressions found in the opposing walls of the mucosal folds conform to shape and size of the morula mass contained, which appear as if slightly retracted as a result of fixation.

In $\mathrm{B}$, figure 20 , is figured one of the sections of a series passing through a morula stage, comprising as estimated 30 cells and measuring $90 \mu$, by $60 \mu$, by approximately $50 \mu$, in which the very beginning of the formation of the segmentation cavity is shown. Near one pole the outermost cells have separated slightly from the more deeply placed cells, so that an irregularly shaped 
cavity, eccentrically placed and passing clearly through two of a series of five sections of $10 \mu$ thickness, is evident. The small cleftlike cavity is bounded by the surrounding cells, the outline of which is distinct. So far as may be judged from the appearance noted as presented in the two sections in which this cavity is found, this arose as a single space and as a result of the separation of the enclosing cells.

In $\mathrm{C}$, of figure 20 , there is presented a slightly older stage showing the blastodermic vesicle formation and measuring $80 \mu$, by $50 \mu$, by approximately $50 \mu$, comprising as is estimated, 34 to 36 cells. Unfortunately, the lower part of this vesicle is slightly folded as is shown in the lower left of the figure. The appearances presented in the sections are reproduced as faithfully as could be. Owing to the folding, a portion of the thin wall is cut tangentially. The more darkly colored curved line represents in reality the outer boundary of this portion of the vesicle. The segmentation cavity in this vesicle is distinctly larger than that shown in B of this figure. In the section reproduced the segmentation cavity is bounded for the greater part by four somewhat flattened cells, the increase in the size of the cavity being accompanied, it would seem, by a flattening of the enclosing cells.

In these three closely approximated stages, which, since they are taken from the same uterus are probably separated in time of development by only short intervals, the cells though varying in size and shape, show no essential or fundamental difference in structure, neither in cytoplasm nor nuclei; nor do they show any regularity in arrangement. Only few mitotic figures are to be observed; none in the morula mass shown in $A$, and but two in each of the other two stages, shown in B and C. Judging from these preparations, one would be led to conclude that segmentation cavity formation in the albino rat is not associated nor accompanied by active cell proliferation. This point will be referred to again after the presentation of further material at hand. In slightly older stages of the blastodermic vesicle than here considered, the thicker portion of the vesicle is designated by Sobotta and others as its floor, which is directed 
toward the mesometrial border of the uterine horn, while its thinner portion is designated as its roof, directed toward the antimesometrial border. Therefore, in slightly older stages than thus far figured, the vesicle lies with its long axis approximately at right angle to the long axis of the uterine horn. In further description of the blastodermic vesicle, I shall use the term 'floor' and 'roof' as here specified. In D and E of figure 20, there are reproduced typical sections of the two blastodermic vesicles taken from the uterus of rat No. 68, killed 4 days, 16 hours after insemination. Vesicle $D$ measures $90 \mu$ by $30 \mu$ by approximately $60 \mu$, and is of distinctly ovoid form and slightly compressed. This vesicle is found lying free in a long but narrow fold of the mucosa, both sides of which are slightly molded in conformity with the form of the vesicle. The long axis of the vesicle is still parallel to the long axis of the uterine horn. The roof of the vesicle appears as if slightly contracted, though when traced through the series of six sections it does not appear folded. The roof is composed of only a few cells, perhaps seven in all. The segmentation cavity presents a regular outline. This vesicle supports the contention of Widakowich, that the form of the blastodermic vesicle of the rat is dependent in a measure on the form of the space in which it is found. Vesicle $\mathrm{E}$, of figure 20 , measuring $85 \mu$ by $45 \mu$ by approximately $40 \mu$, presents a roof that is slightly folded and shows an early stage in segmentation cavity formation. A figure of the vesicle is included since it represents more clearly than any other blastodermic vesicle of the albino rat in my possession, a differentiation of a layer of surface cells in the mass constituting its floor. This is a question to be more fully considered in further discussion.

In all the measurements of blastodermic vesicles thus far given, even in those given for the morula mass shown in A, figure 20 , it is evident that one of the short diameters is appreciably shorter than the other. The vesicles are not only of ovoid form, but slightly flattened, so that even when not folded, the form of the vesicle as seen in section, even when cut parallel to the long axis of the respective vesicles, is dependent in a measure on the plane of the section, whether parallel to the longer or the shorter 
of the two cross diameters. This may be seen from the series of drawings made of a blastodermic vesicle cut cross-wise, taken from the uterus of rat No. 68 , from which were also taken the two vesicles shown in $\mathrm{D}$ and $\mathrm{E}$ of figure 20 . This series of figures is shown in figure 21, in which are reproduced in serial order the seven successive cross sections into which the vesicle was cut. It measures $65 \mu$ by $38 \mu$ by approximately $70 \mu$, and is found at the bottom of a mucosal fold, found at the mesometrial border, and is resting with one side on the epithelial lining of a shallow pit, the other wall of this mucosal fold, also showing a shallow pit, is slightly retracted. From a study of this series

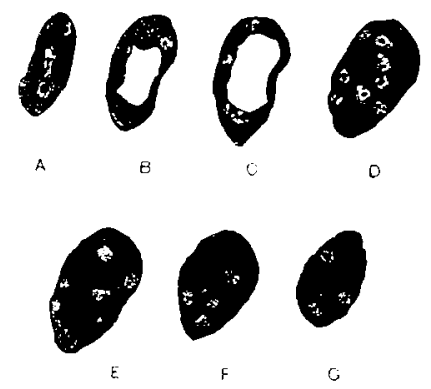

Fig. 21 A complete series of cross-sections of an carly stage of blastodermic vesicle of the albino rat. $\times 200$. Rat No. 68,4 days and 16 hours. $A$ to $C$, sections through roof of vesicle, showing segmentation cavity; D to $G$, sections through floor of vesicle.

of sections, I feel certain that the plane of section is cross and not oblique to the long axis of the vesicle. The roof of this vesicle passes through three sections, A, B and C. The segmentation cavity has thus a depth of less than $30 \mu$. The overlapping of the cells surrounding the segmentation cavity is to be noted, especially as seen in B of this figure. This arrangement of the cells may explain how the cavity may be enlarged without a material increase in the number of the enclosing cells--in part, by a flattening out of the cells, in part by a rearrangement of the relations of the cells. In the figures of the sections passing through the floor of this vesicle, D to $G$, attention is drawn to the size, form and relations of the cells and to the fact that there is no distinct covering layer. In this series of sections, there are 
shown in all 35 nuclei, two of which are in a late diaster phase. By excluding the nuclei that appear to be cut in two, appearing thus in two successive sections, I estimate that the blastodermic vesicle is made up of only about 30 to 32 cells.

In figure 22, there are reproduced typical sections of four blastodermic vesicles taken from the uterus of rat No. 53, killed five days after the beginning of insemination. This uterus contained in all, eight vesicles, one of which was distinctly pathologic. The four vesicles selected for reproduction and discussion present each certain characteristics worthy of consideration. Vesicle $A$, which presents an early stage of segmentation cavity forma-

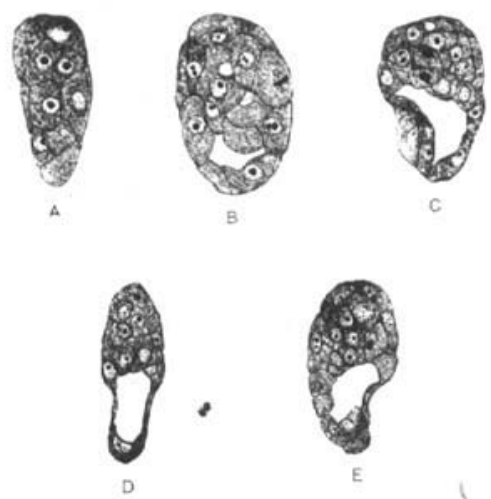

Fig. 22 Sections of early stages of blastodermic vesicle of the albino rat, $\times 260$. Rat Yo. 53, 5 days.

tion is of interest owing to the number of mitotic divisions it contains. As a rule, I have noticed only a few mitoses at this stage. In this vesicle, which measures $90 \mu$ by $55 \mu$ by approximately $40 \mu$, there are no less than five mitoses to be noted, three of which are in cells forming the roof of the small segmentation cavity, and are included in the section figured. This is the only vesicle in my possession in which an increase in the size of the segmentation cavity is accompanied by active mitoses in the cells bounding it. The vesicle lies free in the uterine lumen, one wall of which is only slightly pitted. In B of figure 22 is reproduced a section of a blastodermic vesicle, measuring $90 \mu$ by $55 \mu$ by approximately $45 \mu$. It is evident that this vesicle 
passes through five sections of $10 \mu$ thickness, though one of the end sections, the fifth section of the series, seems to have fallen out during manipulations of staining and mounting, since the preceding, or fourth section does not quite complete the series. This vesicle lies free in the lumen of the uterus, and there is evident only a shallow pit in the mucosa juxtaposed. In this vesicle the cells forming the roof of the segmentation cavity are relatively numerous, and are not markedly flattened, and in one an early mitotic phase is recognized. Here again cell proliferation appears to have accompanied increase in size of segmentation cavity.

The vesicle shown in $\mathrm{C}$ of figure 22 , measuring $130 \mu$ by $30 \mu$ by approximately $40 \mu$, lies free in a long, narrow fold of the uterine mucosa, in close proxirnity to a shallow mucosal pit, lined by cubic epithelium; the pit conforming in shape and extent to the form of the side of the vesicle presented to it. Therefore, it would seem that the form of the vesicle as seen in sections of the fixed material is essentially the same as that obtained in vivo. The two vesicles, typical sections of which are shown in $\mathrm{B}$ and $\mathrm{C}$ of this figure, are almost in identically the same phase of development, although their form as seen in sections differs markedly. The plasticity of the living blastodermic vesicles is no doubt such that their form is in a great measure dependent on the shape of the mucosal fold in which they are lodged. In $\mathrm{D}$ of figure 22 , there is reproduced a section of a blastodermic vesicle which points to a stage of development which is slightly more advanced than that shown in previous figures. The vesicle measures $100 \mu$ by $70 \mu$ by approximately $50 \mu$. The roof enclosing the segmentation cavity is slightly folded; a portion of its wall is thus cut tangentially, as shown in the lower left of the figure. The segmentation cavity is distinctly larger than that shown in the preceding figures, and is bounded by a relatively large number of cells, fourteen in that portion of the roof sketched in this figure, one of which is in a mitotic phase. The mass of cells constituting the floor appears as slightly compressed, in consequence of a slight intravesicular pressure which aided in the enlarging of the segmentation cavity. 
The cells forming the roof of the segmentation cavity do not appear so distinctly flattened as is the case in certain of the vesicles figured in figures 20 and 21 . It would appear, therefore, that at least two factors are operative in the increase of size of the segmentation cavity after its anlage - a flattening out and consequent increase of the exposed surfaces of the enclosing cells, and secondly, a cell proliferation; and it would appear that both of these factors may be operative from the time of the beginning of segmentation cavity formation.

Early stages in the blastodermic vesicle formation in the albino rat have been previously described by Robinson, Christiani, Duval, and Widakowich; Selenka's youngest stage is slightly older than any discussed by me. My own observations are wholly in accord with those of Widakowich in so far as his account covers early stages of blastodermic vesicle formation. He discusses and figures, however, only two vesicles, obtained four days after fertilization-'Befruchtung,' in each of which the segmentation cavity presents a smooth and regular outline and is of appreciable size. The observations of the other observers who have considered these stages will be discussed in connection with a very brief presentation of much more comprehensive observations on the mouse in similar stages of development. Of these latter, those of Sobotta ('03) are based on abundant and apparently well fixed material. Sobotta begins his discussion with the consideration of three ova taken from the same mouse, the second half of the fourth day after fertilization, each of which shows beginning of segmentation cavity formation, one of which was cut in longitudinal axis and is figured in his figure 1. This ovum is interpreted as showing that the segmentation cavity arises not as a single space, but as a number of disconnected spaces, which later become confluent and form a single space. A similar observation was made by Van Beneden on the bat, a fact which Sobotta uses to support his contention that the mouse ova studied by him were of normal structure. Melissinos gives a number of figures showing early stages in the formation of the segmentation cavity in the mouse. His figures 21 and 22 (66 hours) are not unlike my own figures shown in B of 
figure 20 and $\mathrm{A}$ of figure 22. According to this observer, the segmentation cavity arises as a single space, due to an accumulation of fluid secreted by the cells of the morula. This secretion is evidenced by globule-like droplets which are shown in his drawings as adhering to certain of the cells bounding the segmentation cavity. In my own preparations of the albino rat, I find no evidence which would lead to the supposition that the segmentation cavity does not begin as a single space nor do I find any evidence of secretory globules as described by Melissinos. Selenka has described quite fully two blastodermic vesicles of the mouse, lying free in the uterine lumen. His account of their structure, supported by two somewhat diagrammatic figures, is as follows: The wall of the vesicle is formed by a layer of covering cells-'Deckzellen'-constituting a covering layer-"Deckschicht or Rauber's layer." The space enclosed by this layer, for about one-third to one-half of its extent, contains the 'formative cells,' for the remainder it contains fluid. The covering cells and formative cells are said to be separated by a sharp line. The formative cells are in all parts separable into two fundamental germ layers. An inner layer, bordering the cavity and constituting the entoderm, is said to be composed of cells possessing more deeply staining nuclei, irregular outline, with tongue-like processes which extend into the cavity, and a granular protoplasm; further, of cells which are more clear, more peripherally placed, and which constitute the ectoderm. Each of these fundamental germ layers consists of a single layer of irregularly formed cells. According to the observations of Selenka, therefore, the floor of the vesicle consists of three layers of cells; an outer covering layer-'Deckschicht' or 'Rauber's layer'-an inner layer of entodermal cells, and an intermediate layer of ectodermal cells. Jenkinson's account reads as follows: "There are present (1) an outer layer, one cell deep, of trophoblast, which is continuous over (2) an inner mass which becomes differentiated into the embryonic epiblast and the hypoblast, and which is quite distinct from the overlying trophoblast, as my specimens invariably show." In Jenkinson's figures 1 and 2, giving early stages of the blastodermic vesicle, there is not shown a differentiation of the inner 
mass into ectodermal and entodermal cells; the outer layer, covering layer, Rauber's cells, or trophoblast, is clearly differentiated from the inner mass by a distinct space. Duval has recognized in early stages of blastodermic vesicle formation of the mouse and rat, in the thicker part of the vesicle, entodermal and ectodermal cells. The former are of irregular form, possess granular protoplasm and are said to possess the property of ameboid movement. The remaining cells are recognized as ectoderm; a distinct covering layer is not recognized. In Christiani's figures (rat), which are, however, so diagrammatic as to be of little value and are evidently drawn from poorly fixed material, entodermal cells, ectodermal cells, and covering cells may be recognized as per legends. Melissinos (mouse), while not describing definitely a peripheral or covering layer, states that outer cells of the thicker pole, like the cells enclosing the segmentation cavity, stain less deeply than do the more centrally placed cells. In earlier stages of vesicle formation, neither in figures nor in text as given by this observer, do I find reference to a differentiation into ectodermal and entodermal cells. The observations of Selenka, Duval, Robinson, Jenkinson, and others, bearing on the structure of the blastodermic vesicle of the mouse and the rat in early stages of development have been so thoroughly and critically reviewed by Sobotta that an extended discussion has here been deemed unnecessary. It may here suffice to say that while Sobotta's observations were made and his discussions based on ova obtained from the mouse, my own observations made on the albino rat are in agreement with his and support the contention that in early stages of blastodermic vesicle formation a differentiation of the thicker part or the floor of the vesicle into a covering, Rauber's cell, or trophoblast layer, and a further differentiation into ectodermal and entodermal cells, is not to be made: we differ in our accounts of the beginning of the formation of the segmentation cavity. An outer or covering layer is suggested in certain of my own preparations, most clearly in that sketched in $\mathrm{E}$ of figure 20 . However, a uniform difference in structure and reaction to staining reagents of the outer layer of cells is not present in my own preparations. None of my own preparations gives evidence of 
such an early differentiation of ectoderm and entoderm as given by Selenka, Duval, Christiani, and others. Cells of irregular outline with tongue-like projections, such as figured by Selenka and Duval I have not observed. The cells constituting the floor or the thick part of the vesicle all present essentially the same structure, while the segmentation cavity, as soon as it presents appreciable size, shows a smooth and regular outline. In figures 1 and 2, of Widakowich's communication, excellent figures of early stages of blastodermic vesicles of the albino rat, there is presented no evidence of a trophoblast layer nor a differentiation of ectodermal and entodermal cells. My own figures, 20 to 22 , were drawn with the aid of camera lucida at a magnification of 1000 diameters and with the use of an intense Welsbach light. They are reduced five times in reproduction. With the exceptions of cell outlines, which as sketched do not in the preparations fall in the same optical plane, and aresketched more sharply than is perhaps warranted, the figures portray quite accurately the structural appearances presented, so far as may be with the use of a single color.

BLASTODERMIC VESICLE, BLASTOCYST, OR GERMINAL VESICLE The material on hand is listed in table 6 .

\begin{tabular}{c|l|c}
\multicolumn{3}{c}{ TABLE 6} \\
\cline { 1 - 1 } Hecord Number & \multicolumn{1}{|c}{ AGY } & NUMger of Vesicles \\
75 & 5 days, 15 hours & 6 \\
91 & 5 days, 16 hours & 2 \\
88 & 5 days, 21 hours & 7 \\
89 & 5 days, 21 hours & 6 \\
73 & 6 days & 10 \\
74 & 6 days & 5 \\
99 & 6 days & 6 \\
100 & 6 days & 10 \\
104 & 6 days & 6 Total 58 \\
\hline
\end{tabular}

During the sixth day, the blastodermic vesicle of the albino rat increases in size relatively rapidly. The greater portion of its wall is, at this stage, composed of a single layer of flattened cells. The vesicles are not as yet attached to the uterine wall, though the uter- 
ine mucosa shows a distinct reaction to their presence. Localized thickenings of the uterine mucosa, sufficient to cause localized swellings of the uterine tube, indicating the position of the ova, are evident. I have experienced more difficulty in successfully fixing the vesicles during this stage than any of the earlier or later stages studied. Although my material contains 58 vesicles of the stage under consideration, none of them may be regarded as being well fixed, and the majority of them are so folded as a result of contraction during fixation that they are of little value as objects for especial study. That the vesicles are still unattached to the uterine wall is readily determined by the fact that the shrivelled vesicles are found lying free in the depressions of the uterine mucosa, lined by a low cubic epithelium, intact throughout, and retaining its normal relation to the mucosa. The molding in these mucosal depressions no doubt gives the size of the respective vesicles as in vivo.

It is not my purpose at this time to consider more than superficially the changes affecting the uterine mucosa during ovum implantation in the albino rat. It is hoped that this may be the subject of a future communication. It is the purpose in the present communication to confine consideration to the development of the ovum itself. Many of the observations recorded by Burckhard on the implantation of the ovum of the mouse and the formation of the decidua, I find equally adapted to similar phenomena in the albino rat. Differences are to be observed in certain details which it is not the purpose to enter into here. Grosser gives a number of excellent figures (67 to 70 , and 112 to 116) showing implantation and decidua formation in the albino rat; to these the interested reader is referred for the present. The thickening of the mucosa affects primarily its antimesometrial portion. During this process of thickening, the mucosal fold in which the ovum primarily finds lodgment, becomes deepened and converted into a funnel shaped crypt communicating with the uterine lumen, and surrounded by the 'Eibuckel,' or oval fold. Burckhard's schematic figures (text figures 2 to 4 ) may be consulted to make the phenomenon intelligible. 
In figure 23, there are reproduced representative sections of five blastodermic vesicles falling to the end of the sixth day after insemination. None of these five vesicles can be regarded as well fixed. All show a certain amount of distortion, much more evident were the entire series of each of the respective vesicles shown. The form of the blastodermic vesicle of the albino rat at this stage of development, as indicated by the molding of the uterine mucosa, is ellipsoid. Their size as in vivo, when distended and of regular outline, again as indicated by the molding of the uterine mucosa, is slightly larger than would be
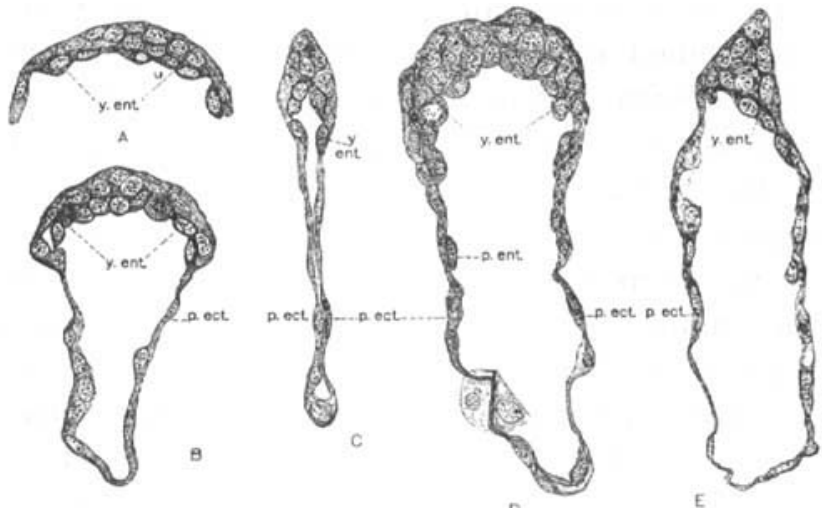

Fig. 23 Sections of blastodermic vesicles or blastocysts of the albino rat. $\times 200$. A and C, rat No. 99, 6 days; B, D, E, rat No. 100, 6 days. y.ent., yolk entoderm; p.ent., parietal layer of entoderm; p.ect., parietal or transitory ectoderm.

supposed from the drawings presented. By reason of this distortion, exact measurements of size cannot be given.

In $A$ of figure 23, there is reproduced that portion of one of the sections of a blastocyst (rat No. 99, 6 days) which passes through its floor; the thin roof of this vesicle was so folded that its inclusion in the drawing was deemed undesirable. However, its floor or the germinal disc, seems to have retained its normal form and structure, presenting when traced through the series a regular concavo-convex, discoidal form. It consists in the main of three layers of cells of polyhedral type; toward the border of the disc, of two layers of somewhat flattened cells, the peripheral layer being continuous with the single layer of cells 
forming the roof of the vesicle, not shown in the figure, and known as the parietal or transitory ectoderm. In the floor or germ disc, there is evident a single layer of cells bordering the segmentation cavity or blastocele and possessing a more granular protoplasm, which stains a little more intensely in Congo red. Their differentiation and characteristic reaction to staining agents is at this stage of development not quite so distinct as in slightly older stages. This layer of cells, similar to that described by Sobotta for the blastodermic vesicle of the mouse in essentially the same stage of development, he has termed the yolk entoderm, 'Dotter entoderm,' a designation which is here followed. In the more superficial layer or layers of cells no characteristic differentiation is observed. In no portion of the floor of this vesicle was a distinct covering or trophoblast layer recognized.

In the vesicle, a section of which is reproduced in $\mathrm{B}$ of this figure (rat No. 100, 6 days), the floor or germ disc presents essentially the same structure as that shown in A. The vesicle shown under B, was also folded, especially its roof, which was drawn to one side and was thus not cut through its entire length in the section figured. Furthermore, the section chosen for drawing does not pass quite through the center of the germ disc, but a little nearer to one of its edges, which probably accounts for the fact that there is recognized for the greater part only a single layer of cells, superimposed over the yolk endoderm, which layer is continuous with the parietal or transitory ectoderm forming the roof of the vesicle. The cells forming the yolk entoderm constitute a single layer and are quite distinctly differentiated; one of the cells shows a mitotic phase. The roof of the vesicle formed by the parietal or transitory ectoderm, is composed of a single layer of flattened cells with flattened nuclei, the form and structure of which is more correctly shown in the right half of the roof wall, which in the section is cut transversely, while the left half, owing to the folding, is shown as cut obliquely.

In C of figure 23 (rat No. 99, 6 days), there is shown a greatly compressed blastodermic vesicle, taken from a series of cross sections of the uterine horn. In this figure there is reproduced the fifth of a series of 10 sections of $10 \mu$ thickness; therefore, 
the third dimension of the vesicle is approximately $100 \mu$. It is evident that had this vesicle been cut in a favorable plane at right angles to the present series, or parallel to the mesometrial plane, its form would have approached that of a circle. I have in my possession one vesicle of this stage of devlopment, similarly compressed, cut parallel to the plane of compression, in which almost the entire roof falls within a single section of $10 \mu$ thickness. The structure of the vesicle shown in $\mathrm{C}$ is very similar to that shown in $A$ and $B$ of this figure. The normal form of this vesicle is quite readily reconstructed from a study of the series of sections into which it has been cut. The cells of the yolk entoderm are evident. The parietal or transitory ectoderm constituting the roof consists of a single layer of much flattened cells, with relatively few nuclei, having, as seen in cross section, a long ovoid form, which, when seen in surface view present a regular, nearly circular outline (see lowermost nucleus in the figure). In similarly compressed vesicles cut parallel to the plane of compression, the germ disc may appear as consisting of three to four layers of cells. In an imaginary section passing in a plane at right angles to that figured in $\mathrm{C}$, and having perhaps a slight obliquity, the germ disc would appear as if much thicker than that shown in A and B of this figure. Such sections may readily lead to false conclusions.

It seems evident from a study of the material at my disposal that during the sixth day after the beginning of insemination in the albino rat, the blastodermic vesicle or blastocyst, which has its anlage in the latter part of the fifth day, enlarges relatively rapidly; this largely owing to a distension of the segmentation cavity or blastocele. This enlargement is accompanied by a flattening and extension of the enclosing roof cells and by a rearrangement of the cells of the floor, which is reduced in thickness to a discoidal area, the germinal disc or germ area, forming about one-fifth to one-sixth of the wall of the vesicle and consisting of two or three layers of cells. During the rearrangement of the cells which constitute the floor of the vesicle, those adjacent to the segmentation cavity or blastocele differentiate to form the anlage of the yolk entoderm. The remaining cells of the ger- 
minal disc, having all essentially the same structure, are of irregular polyhedral form and are mutually compressed. To designate them as a distinct germ layer at this stage seems inappropriate. A differentiation into a layer of covering cells and a layer of formative ectoderm (Selenka) is not to be made. Active cell proliferation as evidenced by mitotic figures does not appear to accompany this enlargement of the vesicle. This phenomenon seems rather to be accomplished by a rearrangement of the cells constituting its floor, however, primarily by an extension and consequent flattening of the cells forming the roof of the vesicle. A similar stage is shown for the mouse by Sobotta ('03) in his figures 3,4 , and perhaps 5 , of mouse vesicles from the fifth day after fertilization-'Befruchtung'. Sobotta had at his disposal much more perfectly fixed vesicles than my material contains. The structure of these vesicles as given by this observer, both as depicted in figures and text, is very similar to the presentation given by me. He also recognizes in this stage the anlage of the yolk entoderm. Figure 30, accompanying the account of Melissinos (mouse, 84 hours) presents a similar stage, although he figures fairly distinctly a layer of covering cells, which if I read him correctly, however, is of only transitory existence. None of the figures given by Robinson and Jenkinson is comparable with figures $\mathrm{A}, \mathrm{B}, \mathrm{C}$, of figure 23 of this account.

In $\mathrm{D}$, of figure 23 (rat No. 100, 6 days) there is reproduced a section of a blastodermic vesicle which on superficial study presents a somewhat later stage of development than those shown in $\mathrm{A}$ to $\mathrm{C}$, of this figure. It is, however, only very slightly older than the three vesicles discussed. Vesicle D, cut in good longitudinal direction, is in reality much more folded than appears from the section figured. Its floor or germ disc is compressed in a plane parallel to that of the plane of section, so that the germinal disc is cut obliquely and not transversely, and thus appears thicker in the section than it in reality is. A distinct layer of covering cells, continuous with the cells of the parietal ectoderm, is evident. Such a layer of covering cells is figured by Selenka, Jenkinson, and Duval. The yolk entoderm has differentiated and extends by perhaps three cells, in the 
section figured, onto the layer of parietal ectoderm. Selenka and Duval, who regard the cells of the primary entoderm as having ameboid properties, are disposed to regard the entodermal cells found lining the parietal ectoderm as having wandered from their seat of origin to the side wall of the vesicle. Sobotta sees no evidence of such wandering of the primary or yolk entodermal cells, but suggests that they are drawn to their position on the wall of the vesicle during its increase in size; their wandering, therefore, is more relative than absolute. Certain cells nearer the edge of the yolk entoderm, having attachment to the parietal ectoderm, which attachment they retain as the vesicle enlarges, are thought to be drawn from their close relation to the yolk entoderm and to appear as scattered cells lining the parietal ectoderm. Now and then, such cells may divide, resulting in further distribution. Sobotta's suggestion seems to me to be more in accord with the observed facts. In vesicle $\mathrm{D}$, the roof, consisting of a single layer of flattened, parietal ectodermal cells, presents several major folds as well as minor folds. The latter particularly account for the variation in thickness of the wall of the vesicle as seen in sections. At the lower left of the figure is seen a portion of the wall as seen cut on the flat, the shape of the two nuclei here shown as seen in surface view may be compared with the long ovoid form of similar nuclei when seen in cross section.

Vesicle $\mathrm{E}$ of figure 23 (rat No. 100, 6 days) presents a stage that is slightly older than the other four vesicles shown in this figure. The floor of this vesicle, the germinal disc, as seen in cross section, presents the form of a triangle with its base resting on the cavity, the blastocele. When compared with the slightly younger stages this portion of the vesicle presents an increase in the number of constituent cells, arranged in irregular layers to the number of five in its thickest portion. The thickening is no doubt in part due to the slight lateral compression of the vesicle, but this does not wholly account for it. The cells constituting this thickened germinal disc are for the main of irregular polyhedral form with relatively large nuclei rich in chromatin. A distinct covering layer is not evident. On its under surface there is found a single layer of cells of yolk entoderm. The 
thin-walled roof of this vesicle, the parietal or transitory ectoderm, deserves no special consideration, except to state that its variation in thickness, as seen in the section figured, is due to the plane of section-cross or oblique of different portions of the wall, owing to slight folding. This vesicle I believe to be in stage of development and structure very similar to that shown by Sobotta ('03) in his figure 6 , mouse vesicle of the first half of the sixth day, and perhaps also figure 31 , of the account of Melissinos, mouse vesicle, end of fourth day, also figure 7 of Jenkinson's article who, however, describes and figures a distinct covering or trophoblast layer.

The cell rearrangement and proliferation resulting in the thickening of the floor or the germinal disc as noted in $\mathrm{E}$, of figure 23, marks the beginning of a much more distinct thickening of this portion of the vesicle, partly due to cell proliferation, in part also due to the rearrangement and enlargement of the constituent cells, during which thickening process this portion of the vesicle grows outward as well as into the cavity of the vesicle, initiating the phenomenon known as the 'inversion of the germ layers' or as 'entypy' of the germ layers, to be discussed as to its anlage in the following section.

\section{LATE STAGES OF BLASTODERMIC VESICLE, BEGINNING OF ENTYPY OF GERM LAYERS}

The material at hand is listed in table 7 .

TABLE 7

\begin{tabular}{|c|c|c|}
\hline HECORD NUMBER & AGE & NLMBER OF VEEICLNS \\
\hline 46 & 6 days, 14 hours & 10 \\
\hline 54 & 6 days, 16 hours & 9 \\
\hline 67 & 6 days, 16 hours & 7 \\
\hline 24 & 6 days, 17 hours & 3 \\
\hline 90 & 6 days, 17 hours & 6 \\
\hline 72 & 7 days & 9 \\
\hline 80 & 7 days & 9 \\
\hline 92 & 7 days & 6 Total 59 \\
\hline
\end{tabular}

The fixation of the blastocysts of the albino rat obtained during the seventh day after insemination was much more 
readily accomplished than in those obtained during the preceding day. Of the 59 vesicles of this stage obtained, many show excellent fixation. The thin wall of the vesicle is no longer so prone to fold as in the preceding stage, and does not readily retract from the uterine epithelium or mucosa, no doubt owing to a distinct adhesion of vesicle wall to the maternal tissue. It is difficult, however, so to orient the vesicles as to obtain sections of a desired plane. The general position of a given vesicle is readily determined, since the enlargement of the uterus marking its location is very evident. The vesicles are located in approximately cylindrical cavities, known as decidual crypts, which are directed toward the antimesometrial border.

These decidual crypts communicate with the lumen of the uterus, which lies eccentric and nearer the mesometrial border, by means of funnel-shaped openings. The decidual crypts or cavities are still lined with uterine epithelium, though this is now much flattened in the immediate vicinity of the vesicle and may be found in part separated from the mucosa of this region. The vesicles are now so placed that in all of them, the thicker portion, the floor of the blastodermic vesicles of younger stages or region of the germinal dise, is directed toward the mesometrial border, thus toward the still patent lumen of the uterus, while the roof of the vesicles is directed toward the antimesometrial border, thus toward the bottoms of the decidual crypts. The general direction of the decidual crypts is in the main at right angle to the long axis of the uterine horn, and directed from the mesometrial to the antimesometrial border. They may deviate, however, from the general direction at various angles and in almost any direction. The decidual crypts as seen in cross section do not as a rule present a circular outline, but appear as slightly compressed from side to side, having thus an oval outline as seen in cross section, with the long axis of this oval space as seen in cross section approximately parallel to the long axis of the uterine horn. Since the direction of the decidual crypts can in uncut material be only approximated, the obtaining of sections cut in a desired plane becomes largely a matter of chance. In a large number of my preparations the contained 
vesicles are cut in an oblique plane, which may deviate only a little from the longitudinal or may approach a cross axis, while only a relatively small number of vesicles were cut favorably in the longitudinal plane, and the majority of these are in series cut parallel to the plane of the mesometrium. The vesicles on which the special consideration of this stage is based are reproduced as seen in sections, in figure 24 .

Vesicle $\dot{A}$, of figure 24 (rat No. 46, 6 days, 14 hours), is drawn from two successive sections. The upper portion of the figure

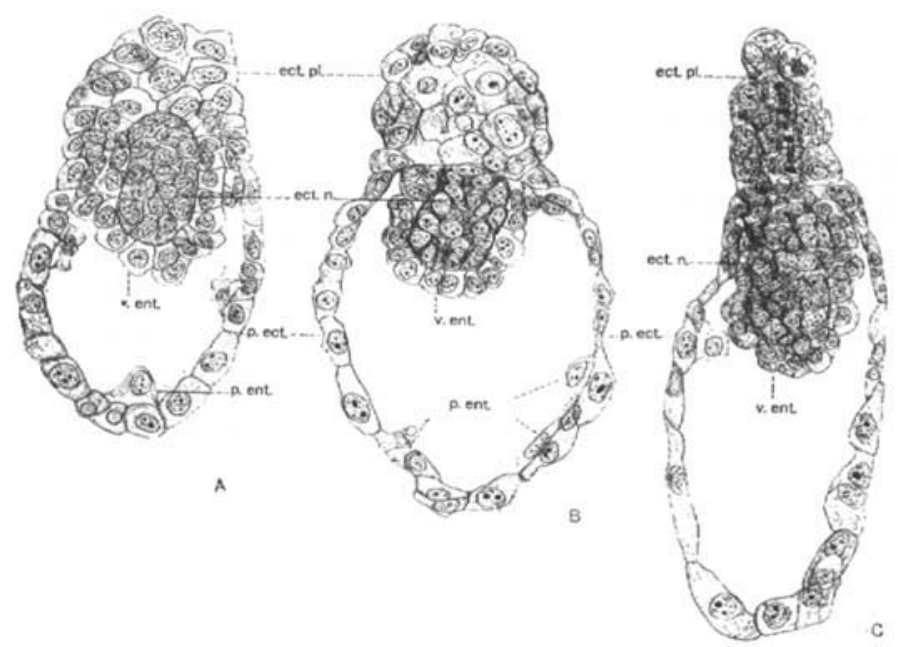

Fig. 24 Sections of blastodermic vesicles or blastocysts of the albino rat showing the early stages of entypy of the germ disc. $\times 200$. A and $B$, rat No. 46, 6 days, 14 hours; C, rat No. 54, 6 days, 16 hours; ect.pl., ectoplacental cone or Träger; ect.n., ectodermal node; p.ect., parietal or transitory ectoderm; $v$. ent., visceral layer of entoderm; p.ent., parietal entoderm.

was drawn under camera lucida from one section, then by superimposing certain of the cells so as to give proper orientation, the lower half of the figure was added from the succeeding section. The slightly oblique plane in which this vesicle was cut made this procedure desirable. This relatively small vesicle seems in excellent state of fixation, as is evident from the symmetrical outline shown by the successive sections of the series. When compared with vesicle $\mathbf{E}$ of figure 23 , though the two are separated in time of development by only a few hours, it is evident 
that a distinct advance in development has taken place. The so-called floor of vesicle $A$, the region of the germinal disc of former stages, directed toward the mesometrial border, is markedly thickened, resulting in an outgrowth toward the mesometrial border and an ingrowth into the cavity of the vesicle. The outgrowth forms the anlage of the 'Träger' (Selenka) or the 'ectoplacental cone' (Duval), and appears to have developed largely as a result of an increase in size of the more superficially placed cells, since cell proliferation is not marked in this region. It is admitted that the critical stages are here lacking in my material. These stages appear to fall to the early hours of the seventh day, the material for which is lacking.

As may be seen from the figure, the cells constituting the anlage of the ectoplacental cone are of relatively large size with large vesicular nuclei, and are continuous at the base with the parietal ectodermal cells which form the roof of the vesicle or its antimesometrial portion. In the cell mass which extends into the cavity of the blastodermic vesicle or blastocyst in which there is recognized the anlage of the 'egg-plug'-'Eizapfen,' or 'egg cylinder'-'Eicylinder' (Sobotta) there is evident a fairly clearly circumscribed compact mass of cells, which stain somewhat more deeply than the surrounding cells and which may be designated as the ectodermal node. It represents the anlage of the true ectoderm of the embryo, as may here be stated in anticipation of further description. In all of the vesicles of this stage of development, even when cut obliquely or in cross section, this small nodule of compactly arranged cells is evident. It is circumscribed both from the cells of the ectoplacental cone as also from the cells lining the blastocele. The metamorphosis leading to the formation of the ectodermal node will receive consideration in a brief general discussion of this stage. The cells covering the egg-plug, and surrounding the ectodermal node, so far as it extends into the blastocele, are arranged in a single layer, forming a dome-shaped membrane, which appears as forced into the cavity of the vesicle consequent on development of the ectodermal node. This layer of cells constitutes the yolk entoderm, the anlage and differentiation of which has been previously 
considered. The antimesometrial portion of this vesicle, its roof, consists of a single layer of somewhat flattened cells, the parietal or transitory ectoderm. The parietal ectoderm presents on its inner surface a few-four in the section figured - entodermal cells of irregular outline. These may be designated, after Sobotta, as cells of the parietal entoderm.

Vesicle B, of figure 24 , taken from the same rat as was vesicle A (rat No. 46, 6 days, 14 hours) presents a very favorably cut vesicle, which, however, is slightly compressed from side to side, so that its form appears more nearly circular in the sections cut in the plane of the figure, than were they cut at right angles to this plane. This is especially true of the ectoplacental cone, which for the greater part appears in only two sections of $10 \mu$ thickness, while in the plane of the figure it measures nearly $90 \mu$. Cognizance of this is to be taken in considering the relative size of the ectoplacental cone as shown in this figure. This vesicle is only very slightly older than that shown in $\mathrm{A}$ of this figure. Its ectoplacental cone is made up of a core of relatively large cells, bordered by more flattened cells, which in this preparation stain somewhat more deeply than do the more centrally placed cells. These covering cells are continuous with the cells of the parietal ectoderm. The cell mass projecting into the blastocele is more definitely circumscribed than in the slightly younger stage shown in $A$ of this figure. The ectodermal node appears as an oval mass composed of compactly arranged cells, and is separable on all sides from the surrounding cells. The yolk entoderm, which may now be known as the visceral layer of the entoderm (Sobotta) passes as a single layer of cells of quite regularly cubic or short columnar form, nearly about the ectodermal node to reach the base of the ectoplacental cone, extending over on the parietal ectoderm at one side (see right side of figure). If few of the cells of the parietal entoderm, three in the figure, are evident. The parietal ectoderm forming the roof or antimesometrial portion of this vesicle consists of a single layer of flattened cells, which rest on, and are adherent to the decidual tissue; the uterine epithelium lining the decidual crypt in which the vesicle is lodged having in part disappeared in the immediate region of the vesicle. 
Vesicle $\mathrm{C}$ of figure 24 (rat No. 54, 6 days, 16 hours) presents a stage which is almost identical in development with that shown in $\mathrm{B}$ of this figure, though in shape these two vesicles, as seen in sections, appear quite different. The vesicle shown in $\mathrm{C}$ is less compressed than the one shown in $\mathrm{B}$, and probably presents more correctly the form of the blastodermic vesicle or blastocyst of the albino rat at this stage of development. The ectoplacental cone presents a cylindrical outline and contains two cells showing mitotic phases, both included in the section figured. Its cells, more particularly the ones bordering the periphery, present a vacuolated protoplasm, the vacuoles containing lightly colored globules which from reaction to the stain are to be regarded as blood cells or fragments of such, which blood cells are regarded as of maternal origin. In this preparation, the decidual crypt contains a small amount of extravasated maternal blood, found in part surrounding the ectoplacental cone; also in the antimesometrial portion of the crypt in relation with the roof of this vesicle. These findings will receive further consideration in the succeeding pages. The cell mass projecting into the cavity of the vesicle, consisting of the ectodermal node and the layer of visceral entoderm is slightly larger than in the preceding stage but presents no special features deserving discussion. The vesicle in the section sketched presents very few cells of the parietal entoderm. The parietal ectoderm forming the roof of this vesicle consists of a single layer of flattened cells in the protoplasm of certain of which vacuolization is evident. Certain of the cells show inclusions of lightly staining globules of a color similar to those found in the cells of the ectoplacenta, particularly evident in the lower right of the figure in which they are represented as uncolored circumscribed areas. The color reaction of these globules is like that of the maternal blood cells and fragments of blood cells found in the decidual crypt in the immediate vicinity of the vesicle, and they are regarded as blood cells or fragments of such, taken up by the cells of the parietal ectoderm at this stage in the development of the vesicle.

The blastodermic vesicles or blastocysts figured in figure 24, represent an important stage in the development of the albino 
rat, as also in a number of other rodents, in that they show the anlage of the phenomenon known as the inversion of the germ layers or entypy of the germ layers. "Inversion of the germ layersBlätterumkehrung"-in the ova of rodents was probably first recognized by Reichert in the guinea-pig, mouse, and rat, though it was much more fully and correctly described by Bischoff as observed in the guinea-pig and a little later by Hensen, also in the guinea-pig. Further observations on this phenomenon were recorded by Kupffer in his study of the development of the field mouse, Arvicola arvalis, and by Fraser on the gray and white rat and the mouse. Selenka gave this question special study, and in a number of monographic communications deals with the phenomenon of Blätterumkehrung as observed in three varieties of the mouse, the white rat, and the guinea-pig. Selen$\mathrm{ka}$ 's observations have formed the basis for future work on this problem. They have been widely accepted and extensively quoted. It was he who introduced the term 'Träger' to denote the cell mass which results from proliferation of the covering cells. His own words concerning this point read as follows:

Während bei dem Kaninchenei, nach erfolgter Sonderung der formativen Furchungszellen in äusseres Ektoderm und inneres Entoderm, die gesammste Lage der äusseren Deckzellen zu einer dünnen resistenten Membran zusammenschrumpft, verdickt sich bei den Nagern mit invertirten Keimblättern der mit den formativen Zellen in Contact befindliche Abschnitt der Deckschicht unter lebhafter Zellvermehrung zu einem sphärischen oder konischen Gebilde, welches ich als 'Träger' bezeichne; * * * * Die Einwucherung dieses Trägers ins Innere der Keimblase hat zur Folge, dass die scheibenförmigen Grundblätter (Ektoderm und Entoderm) sich nicht wie beim Kaninchen zu zwei concentrischer Hohlkugeln erweitern, sondern, ehe sie noch zu dieser Gestalt gelangten, ins Centrum der Keimblase vorgeschofen, vorgestülpt und damit invertirt werden.

In a later publication, this observer also suggested the name 'Entypie des Keimfeldes' as a more comprehensive term than 'Blätterumkehrung' under which may be included types with inversion of the germ field without actual inversion of the germ layers. In later years Duval, Christiani, Robinson, Jenkinson, Sobotta, Kolster, D'Erchia, Spee, Burckhard, Melissinos, Widakowich, Lee and others have studied the earlier developmental 
stages of rodents presenting the so-called inversions of the germ layers. O. Hertwig in his chapter "Die Lehre der Keimblätter" gives a brief résumé of our knowledge of the inversion of the germ layers as observed in certain rodents, noting that three main modifications are to be observed. The first and simplest, as found in the field mouse; the second or intermediate as found in the rat and mouse; the third and most complex as observed in the guinea-pig. Hertwig's account is based largely on the observations of Selenka, the accuracy of which is now questioned from many sides.

My own conclusions concerning the early stages of the entypy of the germ layers in the albino rat are made on stages which do not portray the very beginning of this process. The vesicles shown in figure 24, in which this process is well initiated, however, present appearances, on the basis of which certain conclusions may be drawn. It is the contention of Selenka that the Träger or ectoplacental cone is developed as a result of proliferation of covering or Rauber's cells, superimposed on the formative cells of the germ disc. He is followed in this view by Jenkinson, who states that "At a certain stage this proximal trophoblast (the so-called Rauber's cells of the rabbit) certainly becomes very thin, but it never wholly disappears, and soon thickens again to form the Träger, or, to use a modern expression, trophoblastic syncytium, which is destined to play an all-important part in the formation of the placenta." The account of Melissinos is difficult to follow, owing to his application of the term 'Raubersche Schicht.' The outer layer of the blastocyst in the region of the germinal disc is said to have a transitory existence and to disappear almost completely in the earlier stages of blastocyst formation. In a later paragraph he states, "dass nur die Raubersche Schicht existiert und sogar in den folgenden Stadien mit zahlreicheren Kernteilungsfiguren, und dass sie den Placentarconus liefert." Attention has previously and on a number of occasions been called to the fact that in the albino rat $I$ have not been able to differentiate a distinct covering layer-Deckschicht or Rauber's Schicht (Selenka); trophoblast layer (Jenkinson)and have expressed myself as wholly in accord with Sobotta's 
observations on the mouse egg as concerns this point. He has critically reviewed Selenka's and Jenkinson's contentions as to the participation of the covering layer in the formation of the Träger or ectoplacental cone, reaching the conclusion that there is no evidence in support of this. In accord with Duvaland in this I concur-he states: "Die mesometrale Spitze des 'Trägers Selenkás' ist, wie auch Duval richtig bemerkt, sogar ganz auffällig arm an Mitosen." The anlage of the ectoplacental cone or Träger, it would appear to me, is primarily the result of enlargement of its constituent cells, this enlargement of cells involving the more peripherally placed cells of the somewhat thickened germinal disc. In none of my preparations showing early stages in the formation of this structure are mitotic figures evident. Grosser in his figures 67 and 113, shows a germinal vesicle of the albino rat of $6 \frac{1}{2}$ days in its normal position in the decidual crypt. The vesicle there figured is about identical in time and stage of development to those figured by me in figure 24. In his figures, the Träger $(T r$.$) is represented as consist-$ ing of relatively few cells in which no mitoses are evident. In slightly older stages after the means of nutrition of the vesicles is improved through ingestion of maternal blood cells (Sobotta) mitotic figures may be observed in the ectoplacental cone, as shown in $\mathrm{C}$ of figure 24. In the rat as in Mus sylvaticus and the guinea-pig (Selenka) the ectoplacental cone arises as a solid mass of cells; in Arvicola arvalis (Kupffer) it is at first a hollow structure and is in part formed by invagination; in the white mouse (Sobotta) the form of this cell mass may vary greatly and may be solid or penetrated by a mere slit or again by a more extensive cavity.

The earlier stages in the formation of the egg-plug or eggcylinder I have not been able to follow. In the youngest stage showing this, at my disposal, A of figure 24, it consists of a central node of compactly grouped cells, of polyhedral form, quite definitely demarked from the surrounding cells, and very generally of oval form. This mass of cells I have designated the ectodermal node. In Grosser's figures (67 and 113, e, Ec) an identical structure may be observed, designated as 'Ectoderm der Em- 
bryonanlage.' The same may perhaps be observed in figure 26 , plate 14, of Selenka's account. In figures $26,28,31$, and 33 of Christiani's contribution this may be postulated, though his figures are useless for a close comparison. Duval does not figure this stage. Sobotta's ('03) figure 7, and figure 33 of the contribution of Melissinos, appear to give a corresponding stage for the mouse, but in neither of these figures is the 'ectodermal node' so clearly depicted as in Grosser's and my own figures, at least not until a somewhat older stage. Figure 6 of Sobotta ('03) may very probably be regarded as representing an intermediate stage between that shown in $\mathrm{E}$ of figure 23 and in $\mathrm{A}$ of figure 24. By a proliferation of the cells of the germinal area as shown in the former figure a stage resembling that shown in Sobotta's figure 6 , is readily postulated. That the formation of the ectodermal cells is in part due to rearrangement of the cells of the germinal area $I$ believe to be the case, since cell proliferation is not marked in this stage. The enlargement of the more peripheral cells of the germinal area, leading to the anlage of the ectoplacental cone, would of necessity cause the forming ectodermal node to force the yolk entoderm into the cavity of the vesicle, and thus form the anlage of the egg-plug and initiate the phenomenon of entypy of the germ layers. O. Hertwig, in describing the inversion as observed in the mouse and rat, after considering the formation of the Träger through proliferation of the cells of the Deckschicht, following here Selenka's account, states, referring to the Träger, "Durch ihn wird der formative Teil des Ektoblasts nach dem Centrum der Blase vorgetrieben, wobei er sich in eine allseits abgegrenzte Epithelkugel umwandelt." And again, in referring to the development of the guineapig, he states: "Wie bei Maus und Ratte zieht sich das formative Ektoderm zu einer Epithelkugel zusammen." Hertwig thus appears to regard the formation of the 'Epithelkugel,' the ectodermal node, as in part at least developed owing to a rearrangement of the cells of the germinal disc. After the formation of the egg-plug or egg-cylinder that portion of the yolk entoderm which covers it is designated by Sobotta as the visceral layer of the entoderm. The scattered entodermal cells, attached 
here and there to the inner surface of the parietal ectoderm, in the albino rat at no time forming a continuous layer, he has designated as the parietal entoderm. He is followed in this by Widakowich. This nomenclature has been used by me in the sense employed by Sobotta. The parietal or transitory ectoderm (Kolster's 'feinfasserige Haut') forming the roof or antimesometrial portion of the vesicles, is constituted of a single layer of flattened cells, which in the rat show no regional differentiation. The resorption of maternal blood, incidentally noted with reference to cells of the ectoplacental cone and certain of the cells of the parietal ectoderm in connection with vesicle $\mathrm{C}$ of figure 24, to which phenomenon attention has been drawn by Sobotta and Kolster for the mouse, will receive further consideration in the discussion of older stages.

\section{DEVELOPMENT AND DIFFERENTIATION OF THE EGG-CYLINDER}

The material at hand is listed in table 8 .

TABLE 8

\begin{tabular}{c|l|c}
\hline \multirow{2}{*}{ RECORD NUMBER } & \multicolumn{1}{|c|}{ AGE } & \multirow{2}{*}{ NUMBER OF OVA } \\
17 & 8 days, 17 hours (?) & 2 (not all eut) \\
35 & 8 days, 18 hours (?) & 6 \\
21 & 7 days, 16 hours & 10 \\
66 & 7 days, 16 hours & 7 \\
27 & 7 days, 17 hours & 7 \\
89 & 7 days, 20 hours & 5 \\
81 & 7 days, 22 hours & 7 \\
94 & 8 days & 7 \\
95 & 8 days & 9 \\
96 & 8 days & 5 \\
\hline
\end{tabular}

For the stages showing the development and differentiation of the egg-cylinder in the albino rat I am able to present a series of stages which follow one another in close succession. The figures presented are in themselves so elucidative that an extended description is obviated. The stages under consideration fall within the eighth day after the beginning of insemination, judging from the great majority of the specimens at my disposal, although two rats (Nos. 17 and 35) killed in the latter 
half of the ninth day, contained stages which are younger than nearly all of those obtained the latter half of the eighth day. I am unable to state whether this is owing to a retardation in the rate of development of the ova in rats Nos. 17 and 35, or due to an error of record. The record gives date and hour of insemination and of killing, and $I$ have no reason to doubt its accuracy. However, the two rats in question give the only instances of marked deviation from what appears as a normal rate of development as presented by the bulk of my material. Sobotta ('11) has called attention to the difficulty of obtaining successively staged material in the mouse, and cites Kolster as contending: "Man könne auf die Altersbestimmung gar nichts geben." During this stage of development the decidual crypts lodging the ova are deeper than in the preceding stage, their mesometrial portion being narrower, though they are not as yet separated from the uterine lumen. The orientation of the decidual crypts and the contained egg-cylinders is perhaps more readily made than in slightly younger stages, though not definitely enough to insure the cutting of sections in a given plane. Sections of the egg-cylinder cut in the longitudinal plane may be obtained by cutting parallel to the plane of the mesometrium or at right angles to the same. However, it is still largely a matter of chance as to whether the sections obtained pass through the midplane or at an angle thereto.

In figure 25, there are reproduced representative sections of three germinal vesicles taken from the same uterus (rat No. 35, 8 days, 18 hours) which show three closely approximated early stages in the development of the egg-cylinder. None of these three vesicles is cut in exactly the mid-longitudinal plane; especially is this true of the ends of the vesicles. Furthermore, the antimesometrial portion of each, lower part of the figure, composed of the thin-walled parietal ectoderm, shows a certain amount of folding, so that a portion of each wall is cut en face instead of en profile. The appearances here presented by the antimesometrial portion of these vesicles is not to be confused with a 'giant cell' formation of this portion of the roof of the vesicle, described by Sobotta in his earlier publications, but corrected and retracted 
in his later communications. Vesicle A, figure 25, when compared with vesicle $\mathrm{C}$ of figure 24 , shows only a slight difference in degree of development. Vesicle $A$ is of more elongated and of more distinctly cylindrical form. Its thin-walled portion (an-

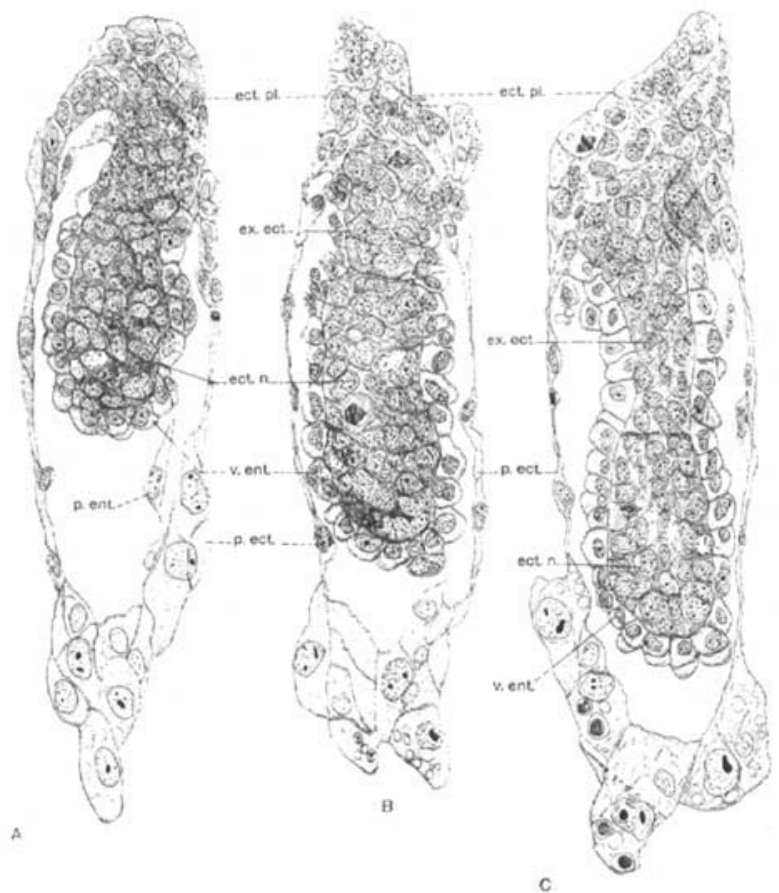

Fig. 25 Longitudinal sections of blastodermic vesicles of the albino rat, showing entypy or inversion of germ layers with early stages in egg-cylinder formation. The ectoplacental cone of each is not cut through its entire length and the lower portion of each vesicle is slightly folded. $\times 200$. A, B, and C, rat No. 35, 8 days, 18 hours, after insemination. To fit properly into the entire series these three vesicles should be from the early hours of the seventh day after insemination. ecl.pl., ectoplacental cone or Träger; ect.n., ectodermal node; ex. ect., extraembryonic eetoderm, early stage of its ingrowth shown in vesicle $\mathrm{A} ; p$. ect., parietal or transitory ectoderm; v.ent., visceral layer of entoderm; p.ent., cells of parietal entoderm.

timesometrial portion) is longer, its cavity more extensive; this is owing to a further flattening of the cells of the parietal or transitory ectoderm. In vesicle $\mathrm{A}$ in the section preceding the one figured, the ectoplacental cone is thicker by about two 
rows of cells than in the one figured; the section figured not passing through the center of this structure. In vesicle $A$, the ectodermal node, which is distinctly demarked, no longer rests against the base of the ectoplacental cone, as in C of figure 24, but has been forced farther into the cavity of the vesicle by reason of proliferation of the cells at the base of the ectoplacental cone, resulting in the formation of a nearly cylindrically formed column of compactly arranged, polyhedral-shaped cells interposed between the ectodermal node and the base of the ectoplacental cone, but merging into the latter without sharp demarcation. To this mass of cells the name of extraembryonic ectoderm has been given by Widakowich. However, under this term this author includes also the cells of the ectoplacental cone. The ectodermal node is of larger size than in the slightly younger stage, $\mathrm{C}$ of figure 24 , the result of cell proliferation. In the section sketched, three mitotic figures are evident in this structure. Its cells are of polyhedral shape, and show no definite arrangement. The ectodermal node and the extraembryonic ectoderm, to the base of the ectoplacental cone, together form a cylindric structure enclosed within a layer of visceral entoderm, which in the section figured is in part cut tangentially, and thus simulates an epithelium consisting of two layers of cells, but consisting in reality of a single layer of cells. Ectodermal node, extraembryonic ectoderm, and the layer of visceral entoderm together form a structure of cylindric shape which extends into the cavity of the vesicle for a distance about one-half its extent, forming the anlage of the egg-cylinder (Sobotta). Very few parietal entodermal cells are to be found on the inner surface of the parietal ectoderm. Vesicles B and C of figure 25 differ from that discussed under $A$, only to the extent to which the ectodermal node has been forced into the cavity of the vesicle owing to further growth of the extraembryonic ectoderm, to the extent that in $\mathrm{C}$, the elongated egg-cylinder approaches the antimesometrial end of the cavity of the respective vesicle. Ectodermal node and extraembryonic ectoderm are at this stage distinctly demarked, though in close apposition. An indenture from the surface at the region of the union of these structures 
with a consequent infolding of the layer of visceral entoderm is not as a rule evident, if so, only very slightly, as to the left in B; such infolding of the visceral entoderm is not regarded as having special significance. These structures, ectodermal node and extraembryonic ectoderm, are appropriately referred to as ectodermal cylinder by Widakowich, and with the visceral entoderm, as constituting the egg-cylinder of Sobotta.

Under $A$ of figure 26 (rat No. 17, 8 days, 17 hours), there is shown a representative section of a vesicle which is only very slightly older than that shown under $\mathrm{C}$, figure 25 . This vesicle was exposed, by teasing away, after fixation, the decidual tistue forming one side of the decidual crypt; this being done before embedding; so as to admit of orientation of its long axis. This accounts for the collapsed state of the thin wall of the vesicle and its slight folding, also for the fact that the ectoplacental cone is reflected upon itself. The egg-cylinder is cut in a very favorable longitudinal plane. In its antimesometrial portion, lower part of the figure, the cells of the ectodermal node now show definite arrangement in practically a single layer, with alternating nuclei. The beginning of a central cavity is evident with reference to which the cells are arranged. This cavity is the anlage of the 'Markamnionhöhle' of Selenka, more appropriately known as the antimesometrial portion of the proamniotic cavity. The cells forming the wall of the ectodermal vesicle (Ektodermblase, Selenka), derived from the ectodermal node, may now be known as the primary embryonic ectoderm (Widakowich). The extraembryonic ectoderm in the mesometrial portion of the egg cylinder has differentiated to form a relatively long irregularly cylindric structure, continuous with the base of the ectoplacental cone, composed of irregular polyhedral cells, compactly arranged and showing as yet no definite orientation. In these cells active proliferation is evidenced by numerous mitoses. The egg-cylinder is covered by a single layer of cells of the visceral entoderm. Over the antimesometrial end of the eggcylinder, the entodermal cells now present a cubic or thick pavement form, while along the sides of the egg-cylinder they are of columnar form, especially long in the region where the primary 


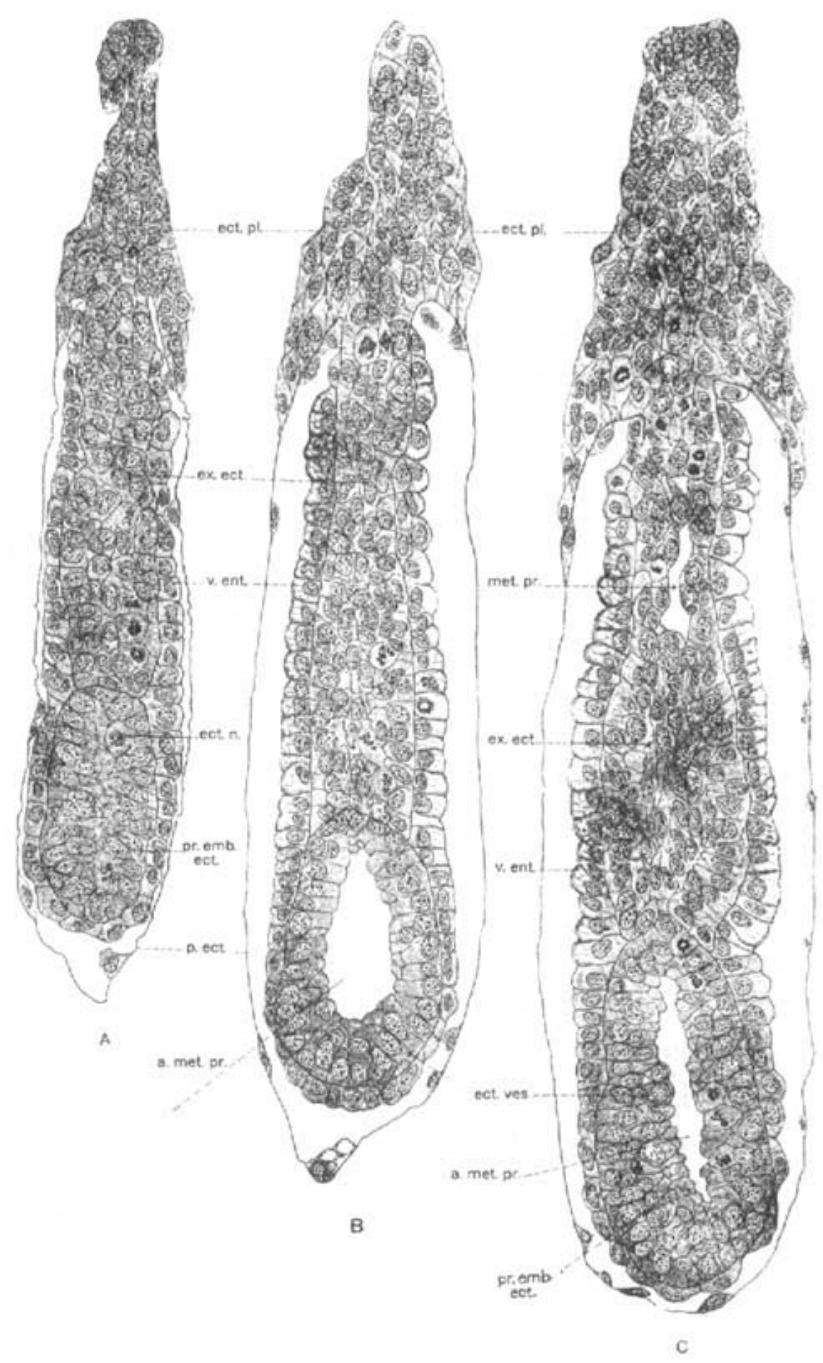

Fig. 26 Longitudinal sections of egg-cylinders of the albino rat, showing the anlage of the antimesometrial and mesometrial portions of the proamniotic cavity. $\times 200$. A, rat No. 17,8 days, 17 hours; $B$ and C, rat No. 81,7 days, 22 hours, after insemination. $A$, shows the very beginning of the development of the antimesometrial portion of the proamniotic cavity developing within the ectodermal node; $C$ shows the beginning of the proamniotic cavity developing in the extraembryonic ectoderm; ect.pl., ectoplacental cone or Träger; p.ect., parietal or transitory ectoderm; ex.ect., extraembryonic ectoderm; v.ent., visceral entoderm in $B$ and $C$, the cells of this layer showing the anlage of the three zones showing absorption of maternal hemoglobin; a.met.pr., antimesometrial portion of proamniotic cavity, developing in the ectodermal node; pr.emb.ect., primary embryonic ectoderm; ect.ves., ectodermal vesicle; met.pr., mesometrial portion of the proamniotic cavity, developing in the extramebryonic ectoderm. 
embryonic ectoderm and the extraembryonic ectoderm meet. The special cytomorphosis undergone by the columnar cells of the sides of the egg-cylinder, in contradistinction to those of the antimesometrial end, will be considered in later pages. The visceral layer of the entoderm extends to the base of the ectoplacental cone, in part passing over onto the layer of parietal ectoderm. In the section figured, cells of the parietal layer of the entoderm are not evident. The ectoplacental cone has grown in length in the direction of the lumen of the uterus or the mesometrial border. In the great majority of my preparations this structure is slightly compressed from side to side, so as to be broader in a plane parallel to the long axis of the uterus. In vesicle $A$, it is cut at right angles to the long axis of the uterus, thus appears as much narrower than in the other two vesicles of figure 26 , which were cut in a plane parallel to the plane of the mesometrium. The increase in size of the ectoplacental cone is the result of active cell proliferation. Mitotic figures to the number of one, two or three, may now be observed in nearly every section of this structure. The parietal or transitory ectoderm, continuous with the base of the ectoplacental cone, has been reduced by this stage to a thin, practically homogeneous membrane, presenting scattered, flattened nucleated cells on its inner surface. This thin membrane is now quite firmly adherent to the wall of the decidual crypt, throughout nearly its whole extent.

Under $\mathrm{B}$ of figure 26 (rat No. 81, 7 days, 22 hours) there is shown a representative section of a vesicle which is slightly more advanced in development than that shown in A of this figure. The antimesometrial portion of the proamniotic cavity, the anlage of which was shown in the preceding stage, is well established. Its wall, consisting of primary embryonic ectoderm is composed of a single layer of cells with nuclei in essentially the same plane. The primary embryonic ectoderm forms a closed vesicle (Ectodermblase, Selenka) distinctly demarked from the extraembryonic ectoderm. In this as in the preceding stage the extraembryonic ectoderm forms a long cylindrical structure continuous at its mesometrial end with the base of the 
ectoplacental cone. The cells are of irregular polyhedral form, compactly grouped, showing as yet no definite arrangement. Cell proliferation as evidenced by mitoses is active, amply accounting for the increase in length of this structure. The visceral entoderm encloses the long egg-cylinder as a single layer of cells and is continuous at its base with the parietal entoderm, well shown at the left of the figure. The ectoplacental cone of this vesicle is very favorably cut in a plane parallel to the long axis of the uterus. This vesicle was unusually well fixed and may be regarded as showing normal relations of the thin membranous wall, derived from the parietal ectoderm, and of the egg-cylinder, which reaches quite to the antimesometrial end of the vesicle.

Vesicle $\mathrm{C}$ of figure 26 , obtained from the same uterus as was vesicle $B$ (rat No. 81, 7 days, 22 hours), differs from that shown under $\mathrm{B}$, in that it presents the anlage of a mesometrial portion of the proamniotic cavity. In the extraembryonic ectoderm, near its junction with the base of the ectoplacental cone, two irregular spaces may be observed. These are distinctly evident, passing through the entire section, only in the section figured. The antimesometrial portion of the egg-cylinder is not cut quite through its center, so that the primary embryonic ectoderm of the ectodermal vesicle appears as a stratified epithelium, and the antimesometrial portion of the proamniotic cavity appears as relatively small, this owing to a slight curvature shown by this egg-cylinder. The other features presented by this vesicle are sufficiently well portrayed in the fgure to obviate the necessity of further description.

In figure 27, there are shown three further stages of egg-cylinder differentiation, showing progressively older stages than shown in the preceding figure. Under A of this figure, there is reproduced a representative section of a vesicle taken from the same uterus as were vesicles $\mathrm{B}$ and $\mathrm{C}$ of figure 26 (rat No. 81, 7 days, 22 hours). The figure is not of a single section, but is combined from two sections, superimposed so as to give correct dimensions and relations. The egg-cylinder of $\mathrm{A}$ of this figure differs from that shown in $\mathrm{C}$ of figure 26 , in that the mesometrial 


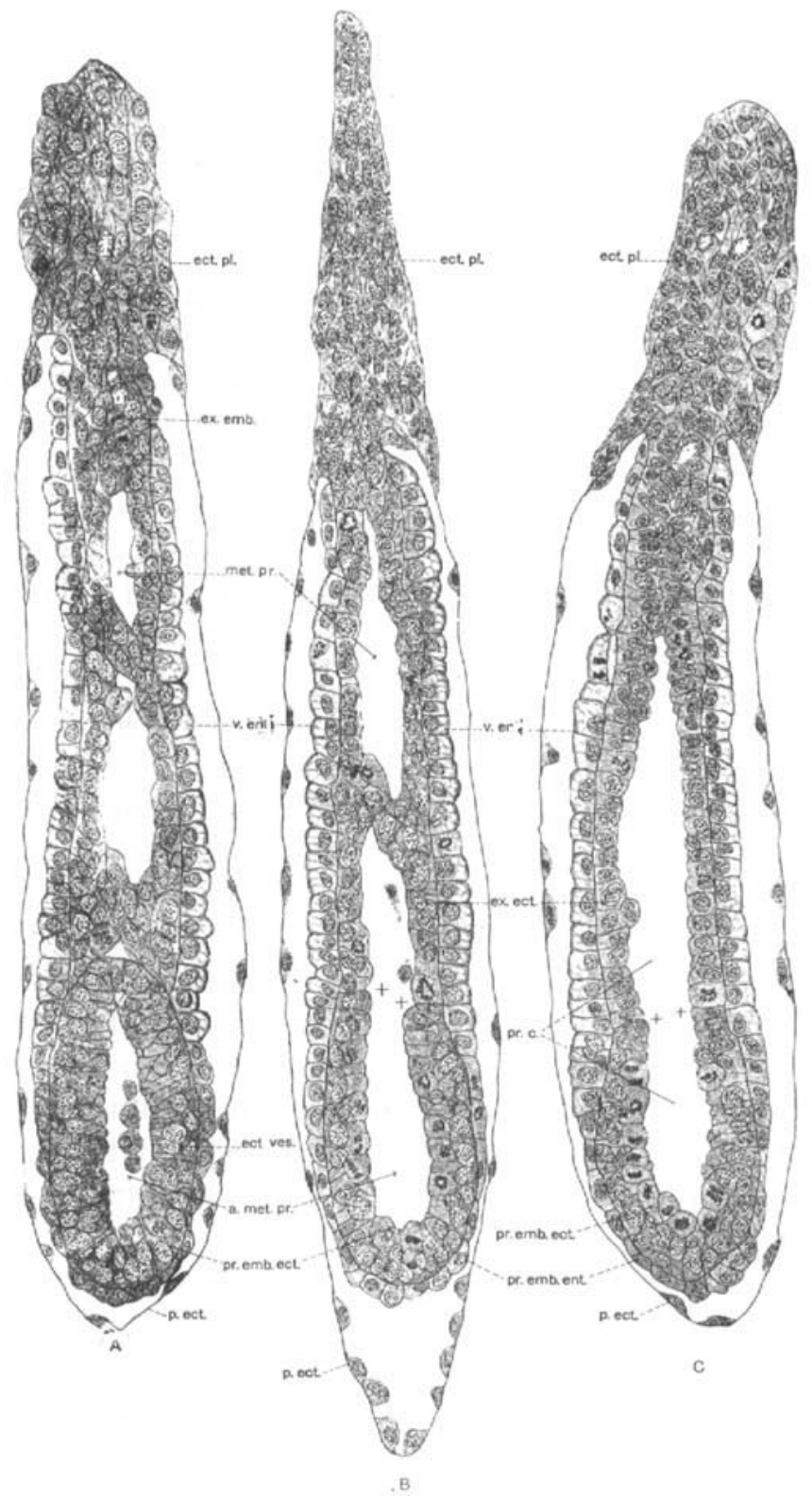

Fig. 27 Longitudinal sections of egg-cylinders of the albino rat showing fusion of the antimesometrial and the mesometrial portions of the proamniotic cavities. $\times 200$. A, rat No. 81,7 days, 22 hours; B, rat No. 96, 8 days; C, rat No. 94, 8 days, after insemination; ect.pl., ectoplacental cone or Träger; p.ect., parietal or transitory ectoderm; ex.ect., extraembryonic ectoderm; ect.ves., ectodernal vesicle, with wall composed of primary embryonic ectoderm, at + junction with the extraembryonic cctoderm; a.met.pr., antimesometrial portion of proamniotic cavity; met.pr., ntesometrial portion of proamniotic cavity; pr.c., proamniotic cavity; v.ent., visceral entoderm; pr.emb.ent., primary embryonic. entoderm. 
portion of the proamniotic cavity, developing in the extraembryonic ectoderm, is of greater dimension. Two relatively large spaces, bordered by a single layer of cells of the extraembryonic ectoderm, are to be observed. At the junction of the extraembryonic ectoderm and the ectodermal vesicle of primary embryonic ectoderm a further space of triangular outline may be seen. The primary embryonic ectoderm is arranged in the form of an oval-shaped vesicle, forming the antimesometrial end of the egg-cylinder. Its wall is relatively thin at the region of its apposition to the extraembryonic ectoderm, just below the triangular space above mentioned. This ectodermal vesicle is peculiar in that its cavity contains the remains of four cells. A study of the series of sections shows that these cells do not represent the crest of a fold of the wall of this vesicle, since they are not nearly so distinct in preceding and succeeding sections. It may only be conjectured that during the rearrangement of the cells of the ectodermal node, resulting in the formation of the ectodermal vesicle, certain of the cells became separated from the wall and remained free in the cavity. The primary embryonic ectoderm, forming the wall of the ectodermal vesicle is readily differentiated from the extraembryonic ectoderm, both by the fairly sharp definition of the ectodermal vesicle and by reason of the fact that its cells stain somewhat more deeply than do the cells of the extraembryonic ectoderm, as also the cells of the visceral entoderm. In the egg-cylinder shown under B of figure 27 (rat No. 96, 8 days) the antimesometrial portion of the proamniotic cavity, developing in the ectodermal node, and the mesometrial portion of the proamniotic cavity, developing as several discrete spaces in the extraembryonic ectoderm, have in part joined to form a single proamniotic cavity. The mesometrial portion of this cavity is still bridged by a septum of extraembryonic ectodermal cells, closing off a relatively large space found in its mesometrial portion. With the junction of the antimesometrial and the mesometrial portions of the proamniotic cavity, the primary embryonic ectoderm and the extraembryonic ectoderm become a continuous layer, the line of union of the two portions, however, remains evident and is readily recognized in all the egg-cylinders 
of this and older stages, a question which will receive further consideration in following pages.

In $\mathrm{C}$ of figure 27 (rat $\mathrm{N}^{\mathrm{o}} \mathrm{0}$ 94, 8 days) the proamniotic cavity forms a continuous, single space. The figure presented is drawn from two sections; its greater portion, to the base of the ectoplacental cone from one section, the ectoplacental cone from another section. The junction of the membranous wall of the resicle to the base of the ectoplacental cone, in the two sections used for the figure, was superimposed under camera lucida in joining the portions drawn from the two sections. It is believed that the drawing as presented gives correctly dimensions and relations of the different parts of this vesicle. The wall of the antimesometrial portion of the single proamniotic cavity is formed by the primary embryonic ectoderm, the calls of which are for the main of irregular columnar shape, with alternately placed nuclei. These cells are in active proliferation, as is evidenced by numerous mitoses. The wall of the mesometrial end of the proamniotic cavity is formed of a single layer of cells of the extraembryonic ectoderm; these cells are of quite regular shape with nuclei placed in about the same plane. They stain less deeply than do the cells of the primary embryonic ectoderm. In this egg-cylinder (C, fig. 27) the proamniotic cavity does not extend so near the base of the ectoplacental cone as in a number of other preparations in my possession, showing about the same stage of development; in certain of these, the proamniotic cavity extends to near the mesometrial end of the egg-cylinder.

A more definite characterization of the different parts of the egg vesicle of the albino rat at the stage of development shown in C, figure 27 , end of the 8th day, seems desirable, and in doing so I shall use the terminology used by Sobotta and Widakowich. The vesicle under consideration has reached a length of 0.65 mm., and a width of $0.12 \mathrm{~mm}$. Somewhat more than onefourth of its length consists of ectoplacental cone or Träger. The cavity enclosed is derived from the cavity of the blastodermic vesicle with germ disc, the blastocele, and is termed by Sobotta and Widakowich the 'Dottersackhöhle' or yolk-sac cavity. This cavity is bounded by a thin structureless mem- 
brane derived from the parietal or transitory ectoderm and the scattered cells forming the parietal layer of entoderm. This membrane is continuous with the base of the ectoplacental cone and presents scattered flattened cells on its inner surface. I have designated this thin membrane with cells on the inner surface as the parietal or transitory ectoderm (Kolster's feinfaserige Haut). The egg-cylinder which extends to the antimesometrial end of the yolk-sac cavity, encloses the proamniotic cavity, the antimesometrial portion of which is walled by primary embryonic ectoderm, its mesometrial portion by extraembryonic ectoderm, the two forming a continuous layer, with line of union of the two types of ectoderm evident. The uncleaved extraembryonic ectoderm is continuous with the base of the ectoplacental cone. The egg-cylinder is surrounded by a single layer of cells of the visceral entoderm, differentiated so as to consist of a portion which surrounds the antimesometrial end of the egg-cylinder in relation with the primary embryonic ectoderm; the cells of this portion being of a rather thick pavement type, constituting the primary embryonic entoderm, and further a portion which covers the sides of the egg-cylinder, with cells of a columnar type, showing special cytomorphosis. The egg-vesicles and egg-cylinders of the stage of development under consideration and for somewhat older stages show no bilateral symmetry so far as can be discerned by study under the microscope. In longitudinal sections of egg-cylinders, cut respectively in two different planes, at right angles to each other, no difference in form, relation and structure of different parts can be observed. Selenka, Kupffer, Duval, and Sobotta have previously called attention to this fact and shown that longitudinal sections of egg-cylinders may be obtained no matter whether the sections are cut parallel to the plane of the mesometrium, thus parallel to the long axis of the uterus, or at right angles to this plane. The want of bilateral symmetry is also evident in cross sections of the egg-cylinder, as may be seen from the series of sections presented in figure 28 (rat No. 27, 7 days, 17 hours). The cross-cut egg-cylinder, from several sections of which these figures were drawn, represents a stage of develop- 
ment very similar to that of the egg-cylinders shown in longitudinal section in figure 26.

Widakowich, after discussing very briefly the mode of development of the egg-cylinder, discusses and figures an egg-cylinder of the albino rat, obtained $6 \frac{3}{4}$ days after the last coitus. His figure 3 corresponds in stage of development very closely to that shown by me in A of figure 27. In his figures, there is presented an egg-cylinder showing the anlage of the mesometrial
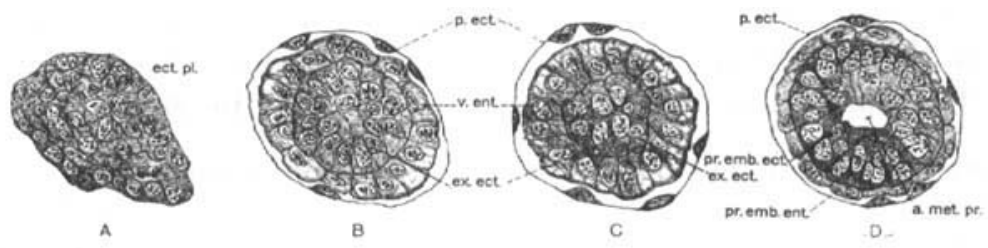

Fig. 28 A series of cross sections at different levels of an egg-cylinder of the albino rat after the anlage of the antimesometrial portion of the proamniotic cavity. $\times 200$. Rat No. 27,7 days, 17 hours, after insemination. The sections selected for the several levels drawn, $A$ to $D$, are as follows: $A$, middle of ectoplacental cone; $\mathrm{B}$ and $\mathrm{C}$, through extraembryonic ectodermal portion of egg-cylinder, just below junction with ectoplacental cone (B), and just above ectodermal vesicle (C); $D$, through middle of ectodermal vesicle. Compare with $B$, figure 26 , a longitudinal section of an egg-cylinder of the same stage of development; p.ect., parietal or transitory ectoderm; ex.ect., extraembryonic ectoderm; pr.emb.ect., primary embryonic ectoderm of the ectodermal vesicle; v.ent., visceral entoderm; pr.emb.ent., primary embryonic entoderm; a.met.pr., antimesometrial portion of proamniotic cavity.

portion of the proamniotic eavity. Emphasis is given to the fact that in the antimesometrial portion of the egg-cylinder, there may be recognized the primary embryonic ectoderm. His own words with reference to this point read as follows:

Der Schnitt zeigt nun sehr deutlich, dass sich die Zellen, die die antimesometrale Höhle so begrenzen, dass die alte Kugel-oder Eiform dieses Teiles noch zu erkennen ist--das primäre embryonale Ectoderm -intensiver färben wie die Zellen des mesometralen Abschnittes oder dic des Ectoplacentarconus - das extraembryonale Ectoderm. Die Kerne zeigen keinerlei Unterschied in der Färbung, wohl aber das Plasma, dass im antimesometralen Teile von dichterer Structur zu sein scheint.

This description corresponds very closely to that given by me for a similar stage. The differentiation of these two kinds of ectoderm was also recognized by Robinson, who states: 
The epiblastic cylinder is closed at its distal end, the trophoblastic at its proximal, and the open ends of the two cylinders are in close apposition, but not indistinguishably fused, for the character of each portion of the ectoderm, after treatment with carmine, is still quite distinctive; the protoplasm of the trophoblast being tinged much more faintly than that of the epiblast.

Selenka, on the other hand, who has recognized in his 'Ektodermblase' with 'Markamnionhöhle' a distinctive structure, believes this to blend completely with the Träger. Since his account with reference to this point has influenced later workers, I may be permitted to quote him in the original. Referring to the 'Ektodermblase' with 'Markamnionhöhle,' he states:

Diesser Ektodermkeim, welcher von dem vorrückenden Trägerzapfen anfänglich sehr wohl abgegrenzt ist, indem beiderlei Gebilde sich in Folge der convexen Krümmung ihrer einander zugekehrten Flächen sozusagen nur in einem Punkte berühren, fliesst endlich mit dem Träger vollständig zusammen, und zwar bei der Waldmaus beror, bei der Ratte und Hausmaus aber nachdem die Markamnionhöhle enstanden war.

That the proamniotic cavity of the egg-cylinder of the albino rat has its anlage in two distinct cavities, the one developing in the ectodermal node in the antimesometrial portion of the eggcylinder, which is the first to develop; the other in the mesometrial portion in the extraembryonic ectoderm, was recognized by Selenka (fig. 30, plate 14, E, Markamnionhöhle, E', falsche Amnionhöhle), Duval (fig. 100,) Robinson, and Widakowich (fig. 3). Corresponding stages of egg-cylinder development as presented by me in figures 26 and 27, for the albino rat, are shown by Sobotta ('02), for the mouse in his figures 12 to 14 and text figures a to $f$. On comparison of my figures with Sobotta's, it becomes evident that the egg-cylinder of the rat is much longer and more slender than that of the mouse. According to the account of Sobotta, the egg-cylinder of the mouse, soon after its anlage, shows by reason of a distinct transverse furrow a division into two parts, an antimesometrial portion of globular form, surrounded by a visceral layer of entoderm, corresponding to what I have designated as the ectodermal node; and a mesometrial portion which early shows the anlage of a proamniotic 
cavity. A lumen is obtained in the antimesometrial portion later than in the mesometrial portion. As development proceeds, this sharp demarkation of antimesometrial and mesometrial portion is gradually lost. This, as stated in his own words, reads:

Sehen wir von dem die (der Keimhöhle zugekehrte) Oberfläche des Cylinders überziehenden Dotterentoderm zunächst ab, so sieht man, dass die Furche, welche die oben erwähnten mesometralen und antimesometralen Abschnitte in Stadium der Fig. 11 u. 12 trennte, jetzt wieder wenig deutlich ist. Es bahnt sich eine Verschmelzung beider Abschnitte wiederum an, was man am leichtesten daraus ersieht, dass bald (Fig. 14) beide Abschnitte ein gemeinsames Lumen erhalten.

With the formation of a continuous proamniotic cavity, this is bordered by a single layer of 'ectodermal cells,' with alternately placed nuclei. The cells are described as being the same throughout; neither in text nor figure does Sobotta differentiate between ectodermal cells derived from the antimesometrial portion of the egg-cylinder and those derived from the mesometrial portion. Melissinos also recognizes antimesometrial and mesometrial portions in the development of the eggcylinder of the mouse, in his figure 34 . According to this observer, the antimesometrial portion of the proamniotic cavity is the first to appear; later it appears in the mesometrial portion, the two cavities joining as development proceeds. The parts of the ectoderm derived from these two portions may be recognized, however, after a single proamniotic cavity has developed. This Melissinos states in the following words: "Trotz aller Vereinigung der beiden Höhlungen bleibt die Unterscheidung des normals abgesonderten antimesomtralen Abschnittes von dem mesometralen immer leicht zu machen, sei es durch eine klare Grenzlinie oder durch eine an der Peripherie des visceralen Dotterblattes befindliche Furche." The account of Melissinos is more in agreement with the presentations as observed in the albino rat than is that of Sobotta.

Selenka, Sobotta, and Melissinos recognize three different regions of constriction to which significance is given, in the egg-cylinder of the mouse. As stated by Sobotta, the first con- 
striction is in the region of the original furrow which demarks the antimesometrial and the mesometrial portions of the eggcylinder, the region of the primary amniotic fold; the second where the mesometrial cavity ends; and the third where the original blastodermic cavity reaches its mesometrial end. The three folds recognized by Melissinos, are characterized by the specificity of the ectoderm. Since his statement concerning this point is somewhat involved, I find it necessary to use his own words; they read as follows, referring to these folds he states:

Der eine derselben $a$ liegt antimesometral und ist der bekannte erste kugelförmige Buckel (Ektoderm) mit den länglichen, cylinderpyramidalen oder polygonal-pyramidalen Zellen; der zweite $b$ liegt in der Mitte und besteht aus kubisch-polygonalen Zellen, und der dritte Buckel $c$, aus polygonalen Zellen bestehend, liegt mesometral und ist von dem mittleren durch Einschnürung, von der Basis des Ectoplacentarconus aber durch die bekannte Urfurche des Eicylinders getrennt, in der sich das viscerale Dotterblatt zum parietalen Dotterblatt umbiegt.

So far as I am able to determine, the account of Melissinos agrees with that given by Sobotta, as concerns the folds of the egg-cylinder of the mouse. Selenka's account need not receive special consideration.

In well-fixed egg-cylinders of the albino rat no such folds are recognized. At the line of junction of the primary embryonic ectoderm and the extraembryonic ectoderm, a slight infolding of the layers, variable in degree, is recognized. Other foldings of the wall of the egg-cylinder I have regarded as accidental and not of special significance. Therefore, I am wholly in accord with Widakowich, who has also discussed this question with reference to the albino rat and has described the low fold in the region of the junction of the primary embryonic ectoderm and extraembryonic ectoderm. Referring to that fold, he states: "Dass war die einzige konstante, bald stärker, bald schwächer ausgeprägte Einschnürung der Proamnionhöhle."

Sobotta deserves credit for having described fully the differentiation and cytomorphosis of the cells of the visceral entoderm of the egg-cylinder, and since his observations on this point apply in the main to the albino rat, they may at this time be given 
consideration. During the early stages of egg-cylinder differentiation and anlage of the proamniotic cavity, the layer of visceral entoderm differentiates into a portion which is in relation with the primary embryonic ectoderm of the antimesometrial portion of the egg-cylinder, in which region the cells of the entoderm are first of short cubic shape, later of the pavement type; this portion may be regarded as forming the primary embryonic entoderm, since it forms the greater part of the entoderm of the embryo. The greater part of the visceral entoderm, that which surrounds the sides of the mesometrial portions of the egg-cylinder, consisting of extraembryonic ectoderm, differentiates into cells of the columnar type. In this latter portion, with the formation of a continuous proamniotic cavity, the entodermal cells undergo characteristic cytomorphosis. In them, as stated by Sobotta, there may be recognized three main zones: (1) a basal zone with denser protoplasm containing the nucleus; (2) a middle zone with markedly vacuolated protoplasm; (3) an outer zone in which hemoglobin granules are recognized, the latter zone staining deeply in eosin. These three zones in the cells of the visceral entoderm in the region of the extraembryonic ectoderm of the egg-cylinder may be recognized in figures 26 and 27 , not so clearly as in Sobotta's colored figures, particularly his figure 17 ('03) and figure 8 ('11). However, I am able to follow closely his description in my own preparations of a somewhat older stage than thus far figured. It is Sobotta's contention that in the extravasated blood surrounding the egg vesicle, in close apposition to its thin outer wall, there may be observed many red blood cells which, though presenting normal form, show a distinctly granular content. These granules stain deeply in eosin and are in shape, size, and reaction to stain very similar to granules found in the peripheral part of the cells of the visceral entoderm. On the outer surface of the thin wall of the vesicle; on its inner surface; in the cells lining this; in the yolk sac cavity; and on the outer surface of the cells of the visceral entoderm, similar granules are found. These appearances are interpreted as showing an absorption of maternal hemoglobin by the entodermal cells of the mesometrial portion of the egg-cylinder. 
Sobotta's statement concerning this point, which, owing to its importance, I quote in full, reads as follows:

Man wird diese mikroskopisch erkennbaren Verhältnisse nicht anders deuten können als in folgender Weise: Die Hämoglobinschollen, die durch die äussere Wand des Dottersackes in die Dottersackhöhle gelangt sind, werden von der Oberfläche des zylindrischen, die ganze Seitenfläche des Eizylinders überziehenden visceralen Dottersackepithels aus resorbiert und zwar geschieht das in der Weise, dass die Hämoglobinschollen zünachst als solche in der Zelle selbst eintreten, dann aber im vacuolisierten Teil der Zelle gleichsam verdaut werden, wobei die einzelnen kleinen Schollen vorher zu grösseren Tropfen zusammen-tliessen scheinen.

My own observations on the albino rat as concerns this phenomenon, more particularly as concerns the structure of the cells of the visceral entoderm in the region of the extraembryonic ectoderm, corroborate Sobotta in many particulars. This question will be again and more fully considered in a contemplated later publication dealing with the implantation and decidua formation in the albino rat. It could not be considered now without a discussion of the changes involved in the development of the decidua, a question which I am not prepared to consider fully now. It may be stated, however, that judging from my own preparations and the figures of Grosser, the extravasation of blood into the egg chamber is not nearly so extensive in the albino rat as is shown in the figures of Sobotta for the mouse.

The thin membrane which surrounds the yolk-sac eavity, which I have designated as the parietal or transitory ectoderm, is derived in development from the parietal or transitory ectoderm, and the relatively few parietal entodermal cells, as described and figured for younger stages. At the stage of egg-cylinder development under consideration - with continuous proamniotic cavity - this structure appears as a thin, practically homogeneous membrane with scattered, flattened nucleated cells on its inner surface. Sobotta regards these cells as derived from the parietal entoderm, the cells of the parietal ectoderm having disappeared. As concerns this, I am unable to speak with certainty, since the Congo red solution used as a double stain is not particularly favorable in differentially coloring these 
cells. However, I am disposed to regard these flattened cells as derived from the parietal ectoderm. The parietal entodermal cells are never numerous in the rat, and mitotic figures are seldom observed in them. With the extension of the vesicle with the enlargement of the blastocele, the cells of the parietal or transitory ectoderm become attenuated until they appear for the greater part as a thin cuticular membrane, and I am disposed to regard the flattened nucleated masses of protoplasm lining the inner surface of this membrane as derived from the cells of the parietal ectoderm.

Much attention has been given to certain large cells which are found in close relation with the outer surface of this thin membrane. These cells, generally referred to as giant cells (Riesenzellen) were, by Duval, Sobotta (earlier publications) and Grosser thought to be of embryonic origin and derived from the cells of the parietal ectoderm. Selenka, Disse, Kolster, Melissinos, Pujiula, Widakowich, and later Sobotta ('11) regard them as derived from the maternal tissue and as representing differentiated decidual cells. It is not my purpose to consider more fully these cells in the present communication, since they are by me not regarded as of embryonic origin. My own observations as concerns them agree in the main with those of Widakowich, who, in the albino rat has followed their origin from decidual cells. Since not of embryonic origin, they have been disregarded in making the figures.

I have previously, in connection with a discussion of the structure of vesicle $\mathrm{C}$, figure 24, alluded to the fact that the cells of the ectoplacental cone as also the cells of the parietal or transitory ectoderm have a phagocytic action for maternal blood cells. This Sobotta has also observed for the mouse, in which he is confirmed by Kolster who has further shown that the cells of the ectoplacental cone also take up fat particles. With the ingestion of maternal blood cells by the cells of the ectoplacental cone, more particularly, with the absorption of hemoglobin by the entodermal cells of the mesometrial portion of the eggcylinder, a period of rapid growth of the egg vesicle is initiated. To this Sobotta has called attention for the mouse; the same 
is evident in the albino rat. Indeed, Sobotta presents the far-reaching conclusion that the explanation of the phenomenon of germ layer inversion or entypy of the germ layers is to be found in the dearth of food supply of the ovum in the stages preceding the formation of more definite relations between the ova or germ vesicles with the decidua. It is thought by this observer that the inversion of the germ disc has for its purpose the increase of the absorptive surface of the visceral or yolk sac entodermal epithelium, which as a differentiated layer comes to surround nearly the whole of the egg-cylinder on completion of the inversion, and is thus increased in extent and brought in relatively close relation with the maternal blood lacunae surrounding the egg vesicle.

\section{LATE STAGES IN EGG-CYLINDER DIFFERENTIATION AND THE ANLAGE OF THE MESODERM}

In the rat series there are found $24 \mathrm{egg}$ cylinders showing the stages of development considered in this section; certain of them are cut longitudinally and others cross-wise.

For the special consideration of egg-cylinder formation just prior to the anlage of the mesoderm, I present two egg-cylinders obtained during the latter half of the ninth day after insemination; one of these was cut longitudinally, the other in favorable crosssection. The egg-cylinder shown in figure 29, rat No. 40, 8 days, 17 hours after insemination, seems unusually well fixed, as evidenced by its symmetrical outline, and is cut in a very favorable plane. The sections are from a series cut at right angles to the long axis of the uterine horn. The decidual erypts lodging the egg-cylinders of this stage are by this time nearly completely separated from the lumen of the uterus, and are surrounded by a well-developed decidua. Extravasated maternal blood nearly surrounds such egg-cylinders.

Fig. 29 Longitudinal, sagittal section of egg-cylinder of the albino rat showing the final mesoderm-free stage. $\times 200$. Rat No. 40, 8 days, 17 hours, after insemination; ect.pl., ectoplacental cone or Träger; p.ect., parietal or transitory ectoderm; pr.emb.ect., primary cmbryonic cctoderm; ex.ect., extraembryonic octoderm; pr.c., proamniotic cavity; v.enl., visceral entoderm, absorptive for maternal hemoglobin, cells showing the three zones described by Sobotta; pr.emb.ent., primary embryonic entoderm. 


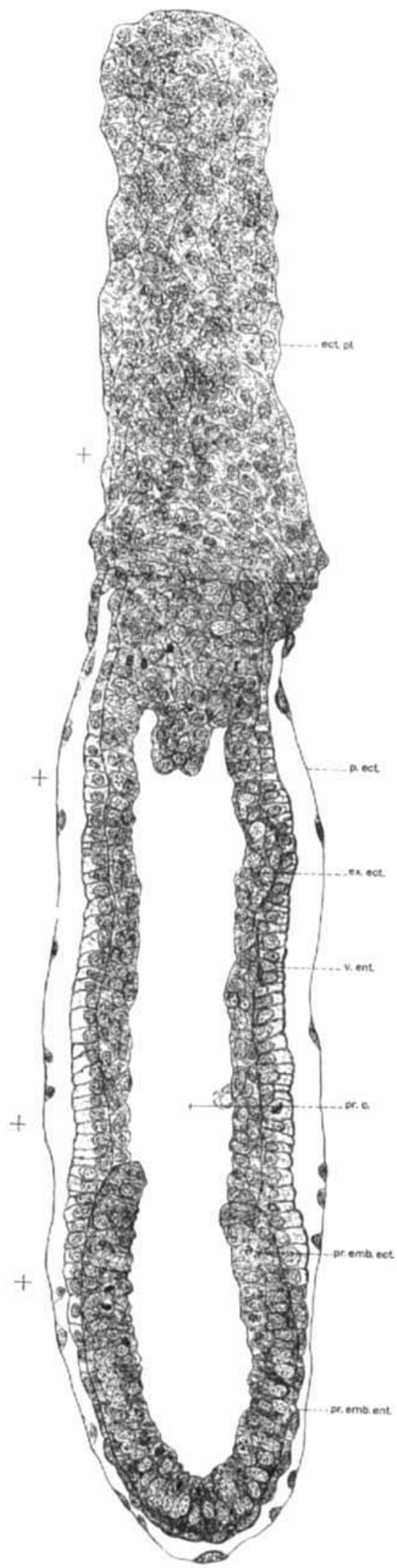


The egg-cylinder shown in figure 29 presents a total length of $1.15 \mathrm{~mm}$., a width of approximately $0.18 \mathrm{~mm}$. The ectoplacental cone presents a length of $0.4 \mathrm{~mm}$. and of the proamniotic cavity, $0.5 \mathrm{~mm}$., of which $0.2 \mathrm{~mm}$. falls to the antimesometrial portion lined by primary embryonic ectoderm. This egg-cylinder differs only in shape and size from that shown in $\mathrm{C}$ of figure 27 , obtained 8 days after insemination. The primary embryonic and extraembryonic ectoderm lining or enclosing the proamniotic cavity are readily differentiated. The primary embryonic ectoderm, derived from the ectodermal node, constitutes a pseudostratified epithelium, composed of relatively long columnar cells, with nuclei radially placed with reference to the lumen of the proamniotic cavity, and shows active cell division, no less than 12 mitotic figures occurring in the section figured. The protoplasm of its cells stains distinctly deeper than does that of the cells of the extraembryonic ectoderm. The cells of the latter are of cubic, short columnar, or polyhedral shape, arranged in a single or double layer, with no definite arrangement of the long axes of its nuclei. It is, therefore, possible readily to distinguish - by reason of shape and size of cells, relative position of nuclei, reaction to stain of protoplasm-between the cells of the primary embryonic and extraembryonic ectoderm, and to determine the sharp line of junction at which the two types of cells form a continuous layer, a fact which will receive further consideration in dealing with the anlage of the mesoderm as observed in slightly more advanced stages. At the mesometrial end of the proamniotic cavity, the cells of the extraembryonic ectoderm become continuous with the cells at the base of the ectoplacental cone; in the region of this junction, active mitosis are often to be observed. In this egg-cylinder the visceral entoderm may readily be differentiated into two portions. The portion which surrounds the primary embryonic ectoderm to nearly the region of its junction with the extraembryonic ectoderm, consists of a single layer of broad, flattened cells which assume a cubic or short columnar shape as the mesometrial border of the primary embryonic ectoderm is approached. This portion of the visceral entoderm we have designated as 
the primary embryonic entoderm. The portion of the visceral entoderm surrounding the sides of the egg-cylinder in the region of the extraembryonic ectoderm, to near the base of the ectoplacental cone, consists of a single layer of columnar cells, regularly arranged and presenting the three zones described by Sobotta. In this stage of egg-cylinder development of the albino rat, the absorption of hemoglobin granules derived from maternal blood cells, first shown for the mouse by Sobotta and Kolster, may be readily made out. In preparations stained in hematoxylin and Congo red, in and on the outer zone of the visceral entodermal cells there may be observed granules staining deeply in the Congo red, presenting the color reaction of hemoglobin. In the middle zone of these cells the protoplasm is distinctly vacuolated, while the inner zone, containing the nuclei, presents a denser protoplasm. The transitory or parietal ectoderm consists of a homogeneous membrane, closely adherent to the maternal decidua, especially along the sides of the egg-cylinder. This layer presents scattered nucleated protoplasmic masses of spindle or dome shape on its inner surface, the relations and distribution of which may be clearly seen in the figure. Attention needs yet be drawn to the ectoplacental cone of the egg-cylinder. Its relation to the maternal decidua is very intimate, so that in places, owing to blood extravasations, it is difficult to differentiate between embryonic and maternal tissue. Many of the cells of the ectoplacental cone present a vacuolated protoplasm, the vacuoles enclosing maternal blood cells. Therefore, they are distinctly phagocytic. Sobotta has also observed and described this for the mouse. Referring to a slightly older stage after the anlage of the mesoderm, his own words read as follows:

Weiterhin sehen wir im Stadium der Fig. 5 auch eine starke Verlängerung und Vergrösserung des Ectoplacentarconus, an dem im mesometralen Teile jetzt Vacuolen auftreten, die in späteren Stadien regelmässig gefunden werden und zwar erfüllt mit mütterlichen Blutextravasaten. Die Ehrnährung des Embryo mit mütterlichem Hämoglobin $* * * *$ ist jetzt im vollen Gang.

Absorption of maternal hemoglobin by the cells of the ectoplacental cone appears to be established at a relatively earlier period in the rat than in the mouse. 
The egg-cylinder presented in figure 29 constitutes the final mesoderm-free stage, the final stage in which no distinct bilaterality may be determined. I assume that the egg-cylinder presented in the figure is cut in the sagittal plane. This assumption is based on the fact that the primary embryonic ectoderm extends slightly farther toward the mesometrial pole on the one side than on the other. In good frontal sections one side of the egg-cylinder in this stage of development should present a mirror picture of the other side. The side on which the primary embryonic ectoderm extends farther toward the mesometrial pole, the left in the figure, is regarded as containing the caudal end of the future embryo. In the primary embryonic ectoderm of this region, it is believed, will develop the primitive streak and groove, and thus the anlage of the mesoderm. Not in all the egg-cylinders of this stage of development found in my series can the caudal end of the future embryonic area be postulated prior to the anlage of the mesoderm, and in cross-sections no such differentiation can be made. The proamniotic cavity of the egg-cylinder shown in figure 29 presents a regular and nearly smooth contour, not divisible into regions such as described for a similar stage for the mouse by Selenka, Melissinos, and Sobotta. A very slight constriction is to be observed only in the region where the primary embryonic and extraembryonic ectoderm are joined in a continuous layer. I am thus wholly in accord with Widakowich, who in describing a similar stage in one of his preparations, states: "Das war die einzige konstante, bald stärker, bald schwächer ausgeprägte Einschnürung der Proamnionhöhle," as previously quoted.

A series of figures of critical regions taken from a series of cross-sections of an egg-cylinder of a stage nearly identical with that shown in figure 29, though of a slightly smaller egg-cylinder, is given in figure 30, rat No. 42, 8 days, 16 hours, after insemination. The sections chosen for the several drawings, $A$ to $D$, are from the following regions, as may be ascertained by comparison with figure 29 ; $\mathrm{A}$, through about the middle of the ectoplacental cone; $\mathrm{B}$, through the proamniotic cavity just below its mesometrial end; C, through the proamniotic cavity just above the 
region of the junction of the primary embryonic and extraembryonic ectoderm; D, a little above the middle of the antimesometrial portion of the proamniotic cavity. The levels of the
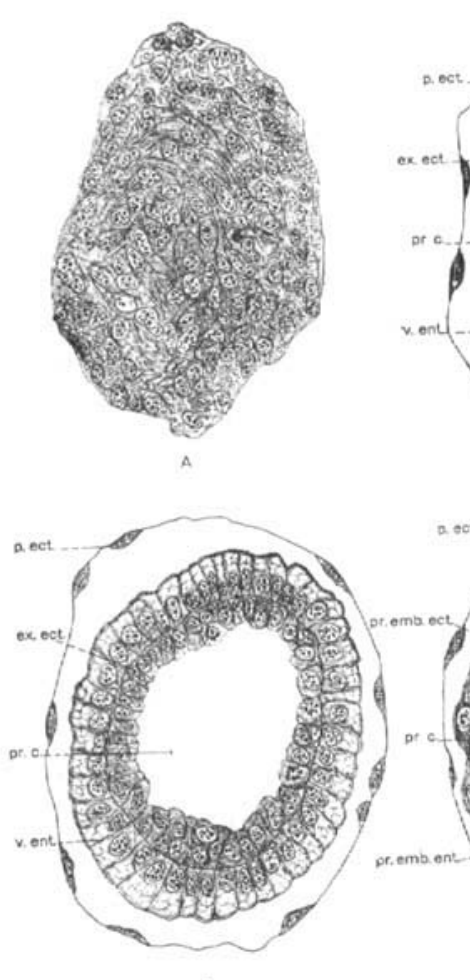

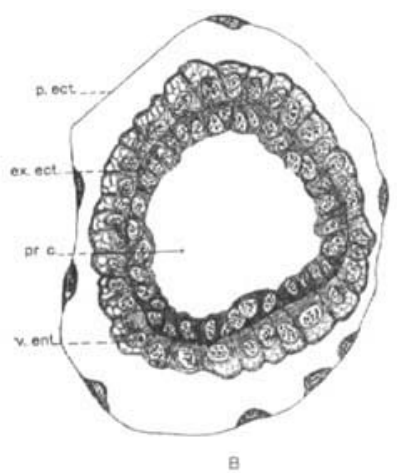

目

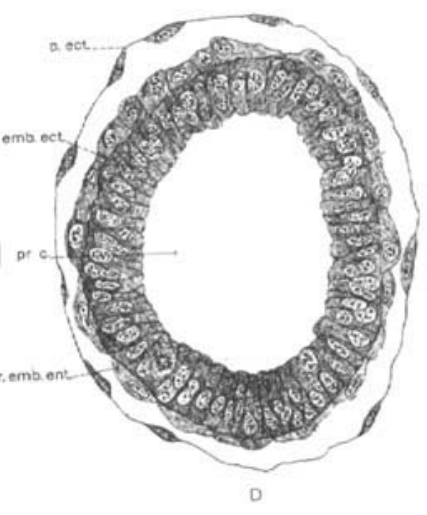

Fig. $30^{-}$Four figures from a series of cross sections of an egg-cylinder of the albino rat in the stage of development shown in figure $29 . \times 200$. Rat No. 42 , 8 days, 16 hours after insemination.

The levels at which the several sections drawn were taken is approximately indicated by the several crosses found to the left of figure 29. A, middle of cctoplacental cone; $\mathrm{B}$, ectoplacental end of the proamniotic cavity; $\mathrm{C}$, just above level of junction of the primary embryonic and extraembryonic ectoderm; a little above the middle of primary embryonic ectoderm. The want of any definite bilateral symmetry of albino rat egg-cylinders of this stage of development is shown by this series of sections; p.ect., parietal or transitory ectoderm; ex.ect., extraembryonic ectoderm, surrounding mesometrial portion of proamniotic cavity; pr.emb.ect., primary embryonic ectoderm; v.ent., visceral entoderm; p.emb. enl., primary embryonic entoderm; pr.c., proamniotic cavity. 
several sections drawn in figure 30 is approximately indicated by the several crosses found to the left of the egg cylinder drawn in figure 29.

In $A$ of figure 30 , there may be observed a vacuolization of the protoplasm of the more peripherally placed cells of the ectoplacental cone, the vacuoles enclosing maternal blood cells. The more centrally placed cells of this ectoplacental cone show a tendency to concentric arrangement. Figures $\mathrm{B}$ and $\mathrm{C}$ present structural appearances nearly identical. The egg-cylinder is bounded by the thin layer of parietal or transitory ectoderm having scattered masses of nucleated protoplasm on its inner surface. This membrane of apparently homogeneous structure stains sharply in well fixed preparations and may be readily discerned. The cells of the visceral entoderm, somewhat taller in the section taken nearer the antimesometrial pole (C), present clearly the three zones to which attention has been drawn. The cells of the extraembryonic ectoderm bounding the mesometrial portion of the proamniotic cavity, are of cubic, short columnar, or polyhedral form disposed in single or double layer, presenting relatively lightly staining protoplasm. In $\mathrm{D}$ of figure 30 , the cells forming the primary embryonic ectoderm are of distinct columnar shape, with relatively deeply staining protoplasm and nuclei arranged nearly in a single layer except for such as show mitotic phases. The cells of the primary embryonic entoderm are of a broad, pavement type for a greater part of the circumference, and may be contrasted with the cells of the visceral entoderm shown in $\mathrm{B}$ and $\mathrm{C}$ of the figure; the latter are absorptive cells, the former not. This series of figures, more especially B, C, and D, show clearly the absence of bilaterality in the egg-cylinders of the albino rat at this stage of development. The slight compression observed in this egg-cylinder, as shown in the figures, I regard as not of moment.

Fig. 31 Longitudinal sagittal section of egg-cylinder of the albino rat showing anlage of the mesoderm. $\times 200$. Rat No. 34, 8. days, 18 hours, after insemination; ect.pl., ectoplacental cone or Träger; p.ect., parietal or transitory ectodern; pr.emb.ect., primary embryonic ectoderm; ex.ect., extraembryonic ectoderm; pr.emb.ent., primary embryonic entoderm; mes., mesoderm in anlage; pr.c., proamniotic cavity; v.ent., visceral entoderm. 


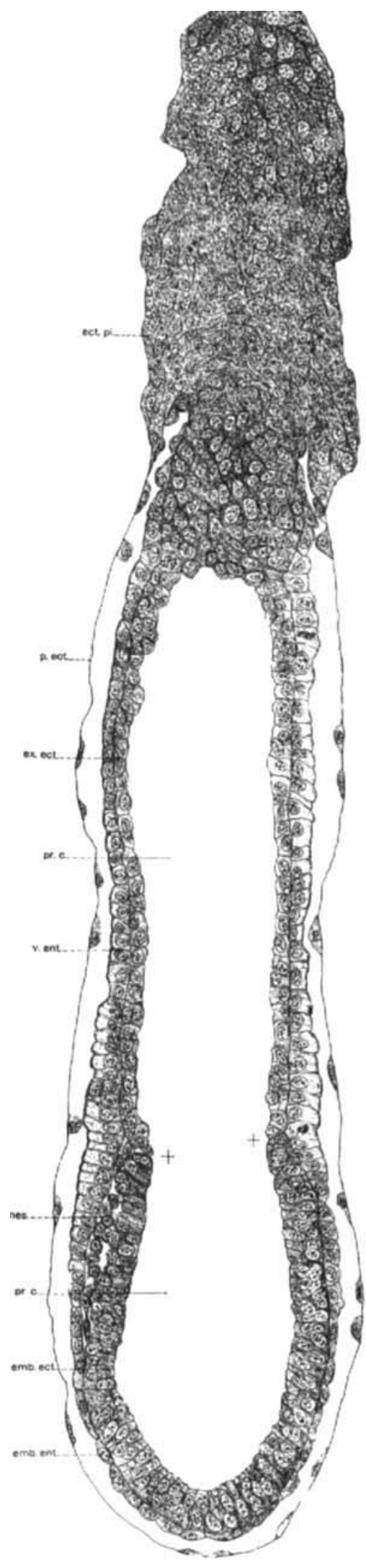


Grosser has figured in his figures 68 and 114, an egg-cylinder of the albino rat which measures nearly $2 \mathrm{~mm}$. in length. The age of this is given as $8 \frac{1}{2}$ days. So far as may be determined from his figures, the preparation is not described in his text, the age, size, form, and structure of the egg cylinder shown in figure 29 and Grosser's figures 68 and 114, are very similar. In Grosser's figures, I see no evidence of his having differentiated between primary embryonic and extraembryonic ectoderm, while the reference letters for ectoderm and entoderm are reversed. Selenka's figure 31 , plate 45 , may be of a similar stage. This figure is, however, too diagrammatic to admit of close study. No difference is shown in the shape and structure of the cells bounding the two parts of the proamniotic cavity. Christiani's figure 39 may be of the same stage, but is too schematically drawn. Figure 4 of the article of Widakowich is of a slightly older stage and presents only a part of the egg-cylinder; it is recorded as about $6 \frac{3}{4}$ days old. The stage under consideration is not figured by Widakowich, although his text description corresponds closely with what has been here presented.

The next stage and the one with which this communication is to be completed is one of importance since it is characterized by the anlage of the mesoderm. My own observations may be introduced with the consideration of an egg-cylinder, a section of which is presented in figure 31 , rat No. 34, 8 days, 17 hours, after insemination. This was cut in the sagittal plane and measures $1.1 \mathrm{~mm}$. by $0.2 \mathrm{~mm}$., of which $0.4 \mathrm{~mm}$. fall to the ectoplacental cone. This egg-cylinder is almost an exact duplicate, both in size and form, of that figured in figure 29 of the same age. In the egg-cylinder shown in figure 31, however, there may be observed, to one side, in the region of the junction of the primary embryonic and extraembryonic ectoderm, and between primary embryonic ectoderm and entoderm, a small group of cells which lie in close relation to the ectoderm and constitute early mesodermal cells. The sections of this series pass not exactly parallel to the mid-sagittal plane throughout the whole extent of the egg-cylinder; especially is this true of its antimesometrial portion, in the region of the primary embryonic 
ectoderm. This portion in the section figured, passes a little to one side of the mid-sagittal plane. The two sections preceding the one figured enclose the mid-sagittal plane, and in them, the group of cells found between primary embryonic ectoderm and entoderm are in closer relation to the ectodermal layer and at all points distinctly separated from the entoderm. They are regarded as having wandered from the primary embryonic ectoderm to the place they occupy, a fact which is more easily ascertained in cross sections of a similar stage, as will appear from further discussion. From a study of very slightly older stages it can be determined that this region constitutes the primitive streak region of the future embryonic area. It is not my purpose at this time and in this communication to give especial consideration to the much discussed question of the origin of the mesoderm in Mammalia. In the rat, this question is complicated by the question of the anlage of the amniotic fold, which separates the proamniotic cavity into amniotic cavity proper and the ectoplacental cavity, the development of which will be considered in a projected contribution. In anticipation of this second publication, however, the following facts may here receive consideration. Widakowich presents in his figure 4, giving only the antimesometrial end of an eggcylinder obtained the latter part of the 7 th day, the anlage of the mesoderm as observed by him. This figure and my own figure 31 present almost identical relations, his figure showing only three mesodermal cells between primary embryonic ectoderm and entoderm. His own words concerning the anlage of the mesoderm in the albino rat, with which I find myself in full accord, except as to the age of the egg-cylinder, read as follows:

Das erste auftreten des Mesoderms beobachtete ich an Keimen vom Ende des 7 Tages. Die ersten Mesodermzellen liegen im Bereiche der vom mesometralen Ende des stärker färbbaren primären embryonalen Ectoderm gebildeten Falte. Es kommt hier eine ganz bestimmte Stelle in Betracht, die dort liegt, wo sich später das hintere Ende des Primitivstreifens befindet.

There is, however, wide divergence of the views of authors as concerns the anlage of the mesoderm in the rat and mouse. 
Selenka, it would seem, in part at least, interpreted correctly the development of the mesoderm in the rat, although a stage showing its anlage was not observed. Duval believes that the mesoderm has origin from a thickened part of the entoderm, probably in the region of the anterior portion of the future embryonic area; the primitive streak was not recognized. Christiani's figures 45 and 47 , transverse sections of the egg-cylinder from the eighth day, give correctly the relative position of the mesoderm with reference to the primitive streak; however, they show stages some little time after the anlage of the mesoderm. According to Robinson, in the early part of the eighth day the cavities of the epiblast (primary embryonic ectoderm) and of the trophoblast (extraembryonic ectoderm) meet and fuse to form a hollow cylinder, the proamniotic cavity. He states that "For a time the united cavities of the epiblast and trophoblast increase in size, together with the general growth of the ovum, and this increase continues until in the latter part of the eighth day the mesoblast appears around the margin of the epiblast where it is in apposition with the trophoblast." Robinson was able to differentiate between the primary embryonic ectoderm (epiblast) and the extraembryonic ectoderm (trophoblast) and his figure 14 (plate 23-24), though schematic, shows that he recognized the positions of the anlage of the mesoderm correctly, as also its derivation from the primary embryonic ectoderm. The observations of Melissinos, bearing on the anlage of the mesoderm have been critically reviewed by both Widakowich and Sobotta, and I am wholly in accord with their views when they state that no credence can be given these observations since it is clear that Melissinos has confused sagittal and frontal sections in such a way as to make his observations of no value. According to Melissinos, the mesoderm arises from the outer surface of the middle fold of the egg cylinder, in the region of its union with the antimesometrial ectodermal fold; it is certain that it does not arise from the part of the eggcylinder that has differentiated from the primary embryonic ectoderm; but, if I interpret him correctly, from the extraembryonic portion of the ectoderm. That Melissinos did not 
have before him the stages showing the anlage of the mesoderm seems clear. Sobotta's ('11) observations, mouse material, deserve fuller consideration. In interpreting his results, I am mindful of the fact that he was unable to locate the line of union between primary embryonic and extraembryonic ectoderm, as can readily be done in suitable rat material, as has previously been shown by Robinson and Widakowich, and to which attention has constantly been drawn in this communication. I am unable to state from personal observation whether in the white mouse these two types of ectoderm which form the lining of the proamniotic cavity, can be differentiated on ascertaining the right technical method. Sobotta's material seems well fixed. If not, it would seem to me difficult to determine definitely the exact place of origin of the mesodermal cells, whether extraembryonic or embryonic. Sobotta recognized the anlage of the mesoderm in the mouse during the last hours of the seventh day or first hours of the eighth day. This is said to appear at the caudal end of the future embryo as a group of loosely arranged cells lying between the inner and outer layers of the egg-cylinder. At the place where the mesodermal cells arise from the inner layer of the egg-cylinder, there is developed a fold, recognized as the caudal amniotic fold ("Schwanzfalte des Amnios"). After discussing these observations at length, Sobotta concludes as follows:

Was die Deutung dieser frühen Stadien der Mesodermbildung in der Keimblase der Maus anlangt, so handelt es sich hier nicht um die Bildung des embryonalen Mesoderms, die erst mit der eigentlichen Gastrulation später einsetzt, sondern um Entstehung ausserembryonalen Mesoderms, besonder des Teils des mittleren Keimblattes, dass bei der Bildung der primären Eihäute, Amnios und Chorion in Betracht kommt und des den ausserembryonalen Teil der Leibeshöhle, das Exocoelom auskliedet, der Höhle, die eben Amnios und Chorion voneinander trennt. Es erfolgt also, um einen kurzen Ausdruck zu gebrauchen, die Bildung des Amniosmesoderms.

An embryonic anlage is said not to exist at this stage; this is recognized only after the development of the primitive streak. It is not my purpose to enter fully into a discussion of this important question in this communication. This would involve 
consideration of older stages, and the making of a number of reconstructions, which it is not contemplated to consider now. It must suffice to state at this time that in the albino rat, as shown by Widakowich and here shown by me, it is possible to delineate clearly the primary embryonic ectoderm and to show that the first evidence of the mesoderm is found antimesometrial to the future amniotic fold and in the region of the future primitive streak; therefore is mesoderm which I would regard as peristomal mesoderm in the sense of $\mathrm{C}$. Rabl, reference to which is made by Sobotta in his discussion of this question. It may be that the rat offers more suitable material for the elucidation of this question than is to be found in the mouse. In the albino rat, the anlage of the mescderm is from the sagittal portion of the caudal region of the primary embryonic ectoderm, the caudal part of the future primitive streak and antimesometrial to the amniotic fold. Sobotta gives very favorable consideration to the observations of Widakowich, touching this question, which he regards as "Bei weitem die beste Darstellung des Gegenstandes." My own observations fully confirm those of Widakowich. These questions will receive fuller consideration in a later publication dealing with the embryology of the albino rat, carrying the development from the time of the anlage of the amniotic fold to the stage of embryo form, the material for which is at hand.

In figure 32 are shown cross-sections of the antimesometrial portion of three egg-cylinders in the region of the developing mesoderm. Sections drawn in A and B, were taken respectively from egg-cylinders obtained from the same uterus as was the one shown in sagittal section in figure 31, rat No. 34, 8 days, 17 hours, after insemination; C, from rat No. 41, 8 days, 16 hours, after insemination. It is very probable that the series from which $\mathrm{A}$ of this figure was drawn, is not cut in exactly the cross plane. A study of the series shows, however, that the deviation from this plane is not marked. The sections from which this figure was drawn pass a little below (antimesometrial) to the region of junction of the primary embryonic and extraembryonic ectoderm. To one side, the lower in the figure, the primary embryonic ectoderm shows a slight thickening and evidence of 

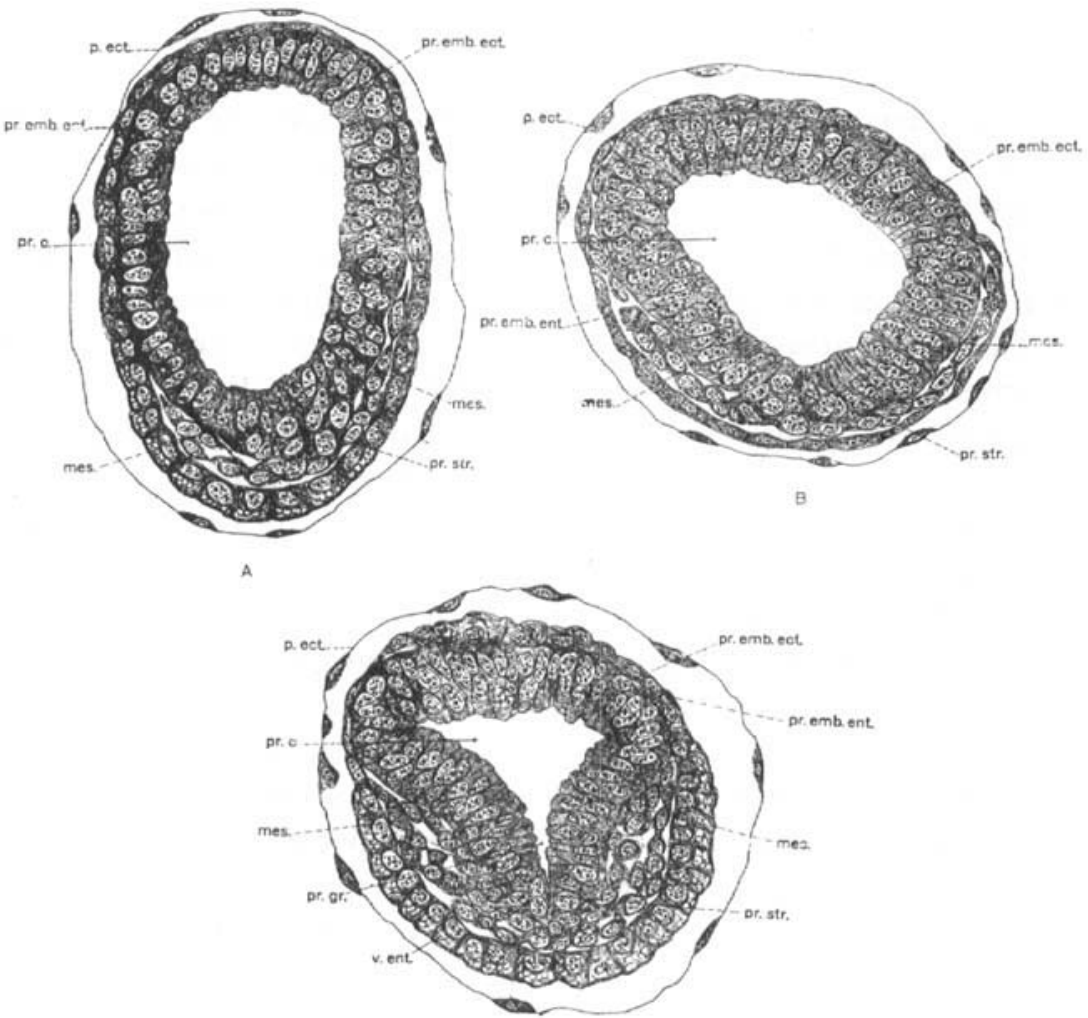

c

Fig. 32 Three cross sections from egg-cylinders of the albino rat, showing early stages in the development of the mesoderm. $\times 200$. $A$ and $B$, rat No. 34, 8 days, 17 hours; C, rat No. 41,8 days, 16 hours, after insemination.

These sections taken from three egg-cylinders are through the primary embryonic ectoderm, near its junction with the extraembryonic ectoderm, thus through the antimesometrial portion of the proamniotic cavity. $A$, early stage, in anlage of the mesoderm; B, anlage of the primitive streak and groove; C, well developed primitive streak and groove, with lateral wings of mesoderm; pr.emb. ect., primary embryonic ectoderm; pr.emb.ent., primary embryonic entoderm; mes., mesoderm; pr.str., primitive streak; pr.gr., primitive groove; p.ect., parietal or transitory ectoderm; pr.c., proanmiotic cavity.

cell proliferation. The cells of this region have not the form of tall columnar cells, such as seen in the greater part of the remaining primary embryonic ectoderm, but are of polyhedral 
form and are continuous, in the mid sagittal plane, with cells that have wandered between the primary embryonic ectoderm and entoderm, cells regarded as constituting the mesoderm. In all of the sections of this series, so far as the mesoderm extends, this is distinctly separable from the entoderm, and is continuous with the primary embryonic ectoderm only along a narrow region of thickened primary embrycnic ectoderm, situated in the mid-sagittal plane, and which may in this series be regarded as the anlage of the primitive streak. From the sides of this region of slightly thickened primary embryonic ectoderm, the extent of which is evidenced by the absence of an external limiting membrane, cells wander laterally to form the mesoderm. $\mathrm{B}$, of figure 32 , presents essentially the same appearance, although representing a slightly older stage. The sections of this series I regard as cut fairly well in a plane at right angles to the long axis of the respective egg-cylinder. The section taken for the sketch is situated a very little further away from the line of junction of the primary embryonic and extraembryonic ectoderm, than is the section the drawing of which is shown in $A$ of this figure, as may be judged from the more uniformly pavement type of the entodermal cells. The triangular form of the proamniotic cavity is regarded as normal, and as indicating an early stage in the anlage of the primitive groove. In this figure, in its lower portion, the region of the primitive streak is readily discernible by reason of the fact that there is wanting here an external limiting membrane, and further by reason of the form of the cells and the form and relative position of their nuclei; certain of these cells indicating, both by their form and their position, the source and the direction of the wandering of the cells which constitute the anlage of the mesoderm. The wandering of the mesodermal cells between the primary embryonic ectoderm and entoderm, to form the lateral mesodermal wings, is clearly shown in this figure, especially to the left. The antimesometrial ends of the egg-cylinders, sections of which are shown in $\mathrm{A}$ and $\mathrm{B}$ of this figure, are as yet free from the invading mesoderm, as is also the part of the egg-cylinders lying opposite the region of the primitive streak, the upper portions of the 
respective figures, these forming the region of the future anterior ends of the respective embryos. In $\mathrm{C}$ of figure 32 is shown a drawing of one of the sections of a series of cross-sections of an egg-cylinder taken from rat No. 41, 8 days, 16 hours, after insemination, presenting a stage in which the primitive groove may be definitely made out. This figure is not unlike figure 6 of the article of Widakowich, obtained from an egg-cylinder secured on the eighth day. Concerning this figure he states: "Das Ectoderm steht in direktem Zusammenhange mit zwei Mesodermzungen die gegen die der Primitivrinne gegenüberliegende Seite zu auswachsen." The section drawn in C of this figure is taken from the region very near the junction of the primary embryonic and the extraembryonic ectoderm, as may be observed from the character of the entodermal cells, in the lower part of the figure. The increase in the thickness of the mesodermal wings, the result, in part at least, of proliferation of mesodermal cells, as evidenced by the presence of mitotic figures, is clearly shown in this figure. The mesoderm is distinctly separable from the entoderm as also from the primary embryonic ectoderm except in the region of the primitive streak and groove. The growth of the mesoderm after its anlage has been correctly shown for the albino rat by Selenka, Robinson, and Widakowich; the latter especially giving excellent figures. His figure 5 is especially instructive. In this, he represents the appearances shown by two views of an isolated egg-cylinder, with the primitive groove in anlage, showing the lateral extensions of the mesoderm. Sobotta ('11) has given the best and most comprehensive account of the anlage and growth of the mesoderm in the mouse. An excellent cross-section of a mouse eggcylinder in the primitive streak stage is presented in his figure 6 , which presents very similar appearances to my $\mathrm{C}$ of figure 32 . None of the figures of cross-sections of egg-cylinders included by me show the very beginning of the anlage of the mesoderm, though $\mathrm{A}$ of figure 32 approaches this very closely, as does also figure 31 , presenting a sagittal section. The evidence at hand warrants the conclusion that in the albino rat, the mesoderm has its anlage in the caudal region of the primary embryonic 
ectoderm, from a narrow zone of cells situated in the region of the future primitive streak. From this region there is an outwandering of cells which invade the potential cleft between primary embryonic ectoderm and entoderm, spreading laterally in wing-like sheets. This I would regard as prostomial mesoderm in the sense of $\mathrm{C}$. Rabl. The anlage of the mesoderm in the albino rat, and the early stages of its lateral extension, with the anlage of the primitive streak and groove, falls to the latter part of the ninth day after insemination.

Beginning with the pronuclear stage, found at the end of the first day, 8 days are required for the completion of the process of segmentation, blastodermic vesicle formation and the formation of the primary germ layers - ectoderm, mesoderm, and entoderm - in all, 9 days out of a possible 21 to 23 days, the normal gestation period of the albino rat.

\section{CONCLUSIONS}

Early stages of mammalian development may readily be obtained from the albino rat (Mus norvegicus albinus). When care is exercised, mating may be observed and the age of the embryo, reckoned from the time of mating (insemination), determined with a fair degree of accuracy. Ovulations occur about the time of parturition and again 29 to 30 days post partem. This latter period is more favorable for obtaining insemination and semination, thus fertilized ova. The process of fertilization probably takes place during the latter half of the first day after insemination.

The pronuclear stage, a stage which extends through a period of perhaps 12 to 15 hours, in the middle phase, is observed at the end of the first day after insemination; the fertilized ova having wandered about one-fourth of the length of the oviduct by that time. Of the two pronuclei, the female pronucleus is slightly the larger. The two pronuclei lie near the center of the ovum, are distinctly membraned, and do not fuse prior to the formation of the first segmentation spindle.

The formation of the first segmentation spindle and the first segmentation occur during the early part of the second day after 
insemination. The resulting 2-cell stage extends for a period of about 24 hours and is found in about the middle of the oviduct. The first two blastomeres are equivalent cells. One of these segments before the other, resulting in a 3-cell stage, present for each ovum for only a relatively short period.

The 4-cell stage is observed at the end of the third day after insemination. The ova have by this time traversed about ninetenths of the length of the oviduct.

The 8-cell stage is observed the latter half of the fourth day after insemination and at the end of the fourth day the ova pass from the oviduct to the uterus in the 12-cell to 16-cell stage. The oolemma is lost usually in the 4-cell stage, the segmenting ova conforming in shape to the general form of that portion of the oviduct in which they are found.

Three successive segmentation stages," spaced at intervals of about 18 hours, resulting in 2-, 4-, and 8-cell stages occur during transit through the oviduct. During the fourth segmentation the ova pass from the oviducts to the uterine horns, at the end of the fourth day.

The mass increase of the ova during the first three segmentations is approximately from $0.15 \mathrm{c.mm}$. in the pronuclear stage to $0.18 \mathrm{c.mm}$. in the 8-cell stage. The slow rate of segmentation and the relatively small mass increase may be attributed to the relative scarcity of the embryotroph during transit through the oviducts.

During the early hours of the fifth day after insemination, all of the segmenting ova are found lying free in the lumen of the uterus, spaced about as in the later stages of development, the fifth series of segmentations having been completed by this time, the resulting morula masses having ovoid form, measuring approximately $80 \mu$ by $50 \mu$ and consisting of from 24 to 32 cells. The mechanism operative in spacing the ova in the uterine horns has not been determined.

The early stages of blastodermic vesicle formation are observed during the middle and latter half of the fifth day. The segmentation cavity begins as a single, irregularly crescentic space, eccentric in position, and arising between the cells of the morula. 
By the end of the fifth day after insemination, all fertilized, normal ova are found in the blastodermic vesicle stage. One pole of each vesicle, its floor, consists of a relatively thick mass of cells, in which there is no differentiation in layers and no evidence of ectodermal and entodermal cells. The other pole of each vesicle, its roof, consists of a single layer of flattened cells, bordering the segmentation cavity.

During the sixth day, the blastodermic vesicles which still lie free in the lumen of the uterus, increase in size, partly as a result of extension of the roof cells, partly owing to rearrangement and flattening of the cells of the floor. This portion of the vesicle now presents the form of a concavo-convex disc, forming about one-sixth of the vesicle wall and consisting, as a rule, of three layers of cells, the inner of which is now differentiated to form the yolk entoderm.

During the seventh day after insemination the blastodermic vesicles become definitely oriented in a decidual crypt, the thicker portion, its floor, being directed toward the mesometrial border. The phenomenon of the "inversion of the germ layers" or "entypy of the germ layers" is initiated, the result of cell rearrangement and cell enlargement in the germinal disc, manifested as an outgrowth to form the ectoplacental cone or Träger and an ingrowth into the vesicle, the anlage of the egg-plug or egg-cylinder. In the egg-plug there is recognized a circumscribed, compact mass of cells, staining more deeply than surrounding cells, which constitute the ectodermal node, the anlage of the primary embryonic ectoderm of the future embryo. This ectodermal node, so far as it extends into the cavity of the blastodermic vesicle, is surrounded by yolk entoderm.

During the eighth day after insemination, the egg-cylinder comes in definite relation with the maternal decidua and receives as embryotroph maternal hemoglobin, partly through phagocytic action of the cells of the ectoplacental cone, partly through absorption of maternal hemoglobin by the cells of the entoderm, initiating a period of very active growth as evidenced by active mitosis. The egg-cylinder increases in length, and entypy is completed. A cavity develops in the ectodermal 
node, the antimesometrial portion of the proamniotic cavity. A little later a second cavity develops in the extraembryonic ectoderm, the mesometrial portion of the proamniotic cavity, the two cavities fusing by the end of the eighth day to form a single proamniotic cavity, lined in its antimesometrial portion by primary embryonic ectoderm, and in its mesometrial portion by extraembryonic ectoderm, the two types of ectoderm forming a continuous layer with the line of junction readily distinguishable. No evidence of bilateral symmetry is at this stage observed in the egg-cylinder.

During the ninth day after insemination there is observed the anlage and the early developmental stage of the mesoderm and the anlage of the primitive streak and groove. The mesoderm has its anlage in the caudal portion of the primary embryonic ectoderm in the sagittal region and is of the nature of prostomial mesoderm, extending laterally in wing-like extensions between the ectoderm and entoderm. 


\section{LITERATURE CITED}

Assheron, R. 1895 A re-investigation into the early stages of the development of the rabbit. Quart. Jr. Mic. Sc., vol. 37, N. S.

1899 a The development of the pig during the first ten days. Quart. Jr. Mic. Sc., vol. 41, N. S.

$1899 \mathrm{~b}$ The segmentation of the ovum of the sheep, with observations on the hypothesis of a hypoblastic origin for the trophoblast. Quart. Jr. Mic. Sc., vol. 41, N. S.

Bischoff, Тн. L. W. 1845 Entwicklungsgeschichte des Hundeeis. Braunschweig.

1852 Entwickelungsgeschichte des Meerschweinchens. Giessen.

Burckmard, G. 1901 Die Implantation des Eies der Maus in die Uterusschleimhaut und die Umbildung deselben zur Decidua. Arch. f. mikr. Anat., Bd. 57.

Christiani, H. 1892 L'inversion des feuillets blastodermiques chez le rat albinos. Arch. de Phys. norm. et pathol., vol. 24 (S. 5, T. 4).

CoE, W. R. 1908 The maturation of the egg of the rat. Science, N. S., vol. 27.

Daniel, J. F. 1910 Observations on the period of gestation in white mice. Jour. Exper. Zool., vol. 9.

D'Erchis, F. 1901 Ueber die Einbettung des Eies und die Entwicklung und den Bau der Allantois-und Dottersackplacenta bei der weissen Maus. Zeitsch. f. Geburtshilfe und Gynaecologie, Bd. 44.

Donatroson, H. H. 1912 The history and zoological position of the albino rat. Jour. Acad. Nat. Sc., Philadelphia, vol. 15, second series.

Duesseri, J. 1908 La spermatogénèse chez le rat. Arch. f. Zellforschung, Bd. 2.

Duval, M. 1891 Le placenta des rongeurs (Suite I). Troisième partie. Jour. de l'anat. et de la phys.

Fraspr, A. 1883 On the inversion of the blastodermic layers in the rat and mouse. Proceed. of the Royal Society, vol. 34.

Grosser, O. 1909 Vergleichende Anatomie und Entwicklungsgeschichte der Eihüute und der Placenta mit besonderer Berücksichtigung des Menschen. Wien und Leipzig.

Heape, IV. 1886 The development of the mole (Talpa curopea), the ovarian ovum, and the segmentation of the ovum. Quart. Jr. Mic. Sc., vol. 26 , N.S.

von Hensen, V. 1876 Beobachtung über dic Befruchtung und Entwickelung des Kaninchens und Meerschweinchens. Zeitsch. f. Anat. und Entwick., Bd. 1.

Hertwic, O. 1906 Die Lehre von den Keimblättern. In O. Hertwig's Handbuch der vergleichenden und experimentellen Entwickelungslehre der Wirbeltiere. Bd. 1, Fischer, Jena.

Hentwig, R. 1906 Der Furchungsprozess. In O. Hertwig's Handbuch der vergleichenden und experimentellen Entwickelungslehre der Wirbeltiere. Bd. 1, Fischer, Jena. 
Hubrecht, A. A. W. 1885 Die Phylogeneșe des Amnios und die Bedeutung des Trophoblast. Verh. Kon. Akad. Wetensch. Amsterdam, Ser. 2 (quoted from $\mathrm{O}$. Hertwig).

Jexkinson, J. W. 1900 A reinvestigation of the early stages of the development of the mouse. Quart. Jr. Mic. Sc., vol. 43, N. S.

KEerbel, F. 1888 Zur Entwickelungsgeschichte des Igels. (Erinaceus europaeus). Anat. Anz., Bd. 3.

Kixg, H. D. 1913 Some anomalies in the gestation of the albino rat (Mus norvegicus albinus). Biol. Bull., vol. 24.

Кінкам, W. B., and BuRR, H. S. 1913 The breeding habits, maturation of the eggs and ovulation of the albino rat. Am. Jour. Anat., vol. 15.

Kiolster, R. 1903 Zur Kenntnis der Embryotrophe beim Vordhandensein einer Decidua Capsularis. Anat. Hefte, vol. 22.

KitpFfer, C. 1882 Das Ei von Arvicola arvalis und die vermeintliche Umkehr der Keimblätter an demselben. Sitz. Ber. d. K. b. Akad. d. Wiss., II Cl, Bd. 5 .

LEe, T. G. 1903 Implantation of the ovum in Spermophilus tridecemlineatus, Mitch. Mark Anniversary Volume. Henry Holt and Co., New York.

Loxg, J. A., and MArk, E. L. 1911 The maturation of the egg of the mouse. Carnegie Institute of Washington, Publication No. 142.

Loxi, J. A. 1912 Studies on early stages of development in rats and mice, No. 3, by Mark and Long. The living eggs of rats and mice with a description of apparatus for obtaining and observing them. University of California Publications in Zoology, vol. 9.

MAxDL. 1908 Über das Epithel im geschlechtsreifen Uterus. Zentralbl. f. Gynäkologie.

Melissinos, K. 1907 Die Entwicklung des Eies der Mäuse (Mus musculus var. alba u. Mus rattus albus) von der ersten Furchungs-phänomenen bis zur Festsetzung der Allantois an der Ectoplacentarplatte. Arch. f. mikr. Anat., Bd. 70.

Prjivla, D. 1909 Die Frage der Riesenzellen bei der Entwicklung der Maus. Actos y memorias Primer Congreso de Naturalistas Españolas. Zaragoza (quoted from Sobotta, 1911).

Reıснект, C. B. 1861 Beiträge zur Entwickelungsgeschichte des Meerschweinchens. Abhandl. d. K. Akad. d. Wissensch. Berlin, Bd. 182.

Robinson, A. 1802 Observations upon the development of the segmentation cavity, the archenteron, the germinal layers, and the amnion in mammals. Quart. Jr. Mic. Sc., vol. 33, N. S.

SElenka, E. 1883 Studien über die Entwickelungsgeschichte der Thiere. I Heft, Keimblätter und Primitivorgane der Maus. Wiesbaden. 1884 Studien über Entwickelungsgeschichte der Thiere. $3 \mathrm{Heft}$, Die Blätterumkehrung im Ei der Nagethicre. Wiesbaden.

1901 Die Placentaranlage des Lutung. Sitzber. d. path. phys. Classe d. Kgl. Bair. Akad. d. Wissensch., Heft I.

Soвotra, J. 1895 Die Befruchtung und Furchung des Eies der Maus. Arch. f. mik. Anat., Bd. 45.

1903 Die Entwicklung des Eies der Miaus vom Schlusse der Furchungsperiode bis zum Auftreten der Amniosfalten. Arch. f. mik. Anat., Bd. 61 . 
Бовотта, J. 1908 Weitere Mitteilung über die Entwickelung des Eies der Maus. Verhandl. der Anat. Gesellschaft.

1911 Die Entwicklung des Eies der Maus vom ersten Auftreten des Mesoderms an bis zur Ausbildung der Embryonalanlage und dem Auftreten des Allantois. I Teil: Die Keimblase. Arch. f. mik. Anat., Bd. 78.

Soвotta, J., and Burckhard, G. 1911 Reifung und Befruchtung des Eies der weissen Ratte. Anat. Hefte, Bd. 42.

von Spee, GraAf F. 1901 Die Implantation des Meerschweincheneis in die Uteruswand. Zeitschr. Morph. Anthrop., Bd. 3.

VAN Beneden, E. 1899 Recherches sur les premiers stades du développement du Murin. (Vespertilio murinus.) Anat. Anz., Bd. 16.

Widakowich, V. 1910 Úber die erste Bildung der Körperform bei Entypie des Keimes. Beiträge zur Entwicklungsgeschichte derRatte. Zeitsch. f. wissensch. Zool., Bd. 94 . 